\section{I'vi'

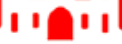

US Army Corps

of Engineers ${ }_{\circledast}$

Engineer Research and

Development Center

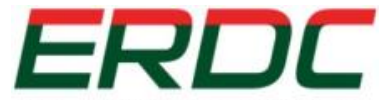

INNOVATIVE SOLUTIONS

for a safer, better world

\title{
Sustainability-Related Publications Calendar Years 2014 - 2015
}
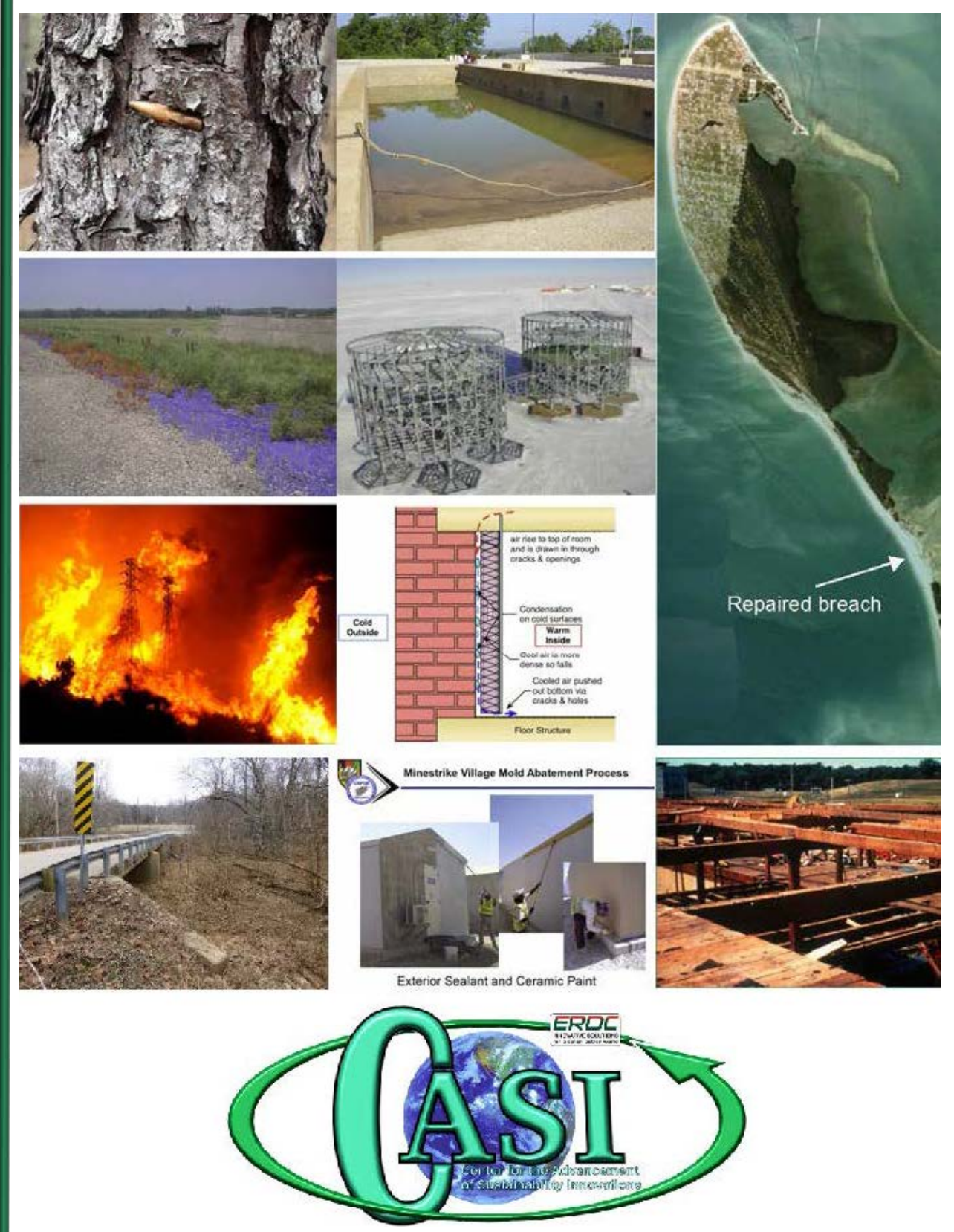



\title{
Contents
}

\author{
I NTRODUCTION 1 \\ ANTI CI PATI NG EMERGI NG I SSUES 5 \\ CLI MATE CHANGE 9
}

SUSTAI NABLE I NSTALLATI ONS - NET-ZERO PLANNI NG 14

SUSTAI NABLE ENERGY SOLUTIONS 17

SUSTAI NABLE WATER \& WASTE RESOURCES 24

SUSTAI NABLE FACI LI TI ES AND I NFRASTRUCTURE 28

SUSTAI NABLE CONTI NGENCY BASI NG 53

SUSTAI NABLE NATURAL I NFRASTRUCTURE 56

GREEN REMEDI ATION AND REUSE 62

ACRONYMS AND ABBREVIATIONS 65

I NCLUDED DOCUMENTS 69

REPORT DOCUMENTATI ON PAGE (SF 298) 73 


\section{Introduction}

The Center for the Advancement of Sustainability Innovations (CASI) was established by the U.S. Army Engineer Research and Development Center (ERDC) as a new capability in 2006, hosted at the Construction Engineering Research Laboratory (CERL) in Champaign, IL. CASI's mission is to focus ERDC expertise, technologies and partnerships towards helping the U.S. Army Corps of Engineers (USACE), the Army, and the Department of Defense (DoD) achieve more sustainable missions, facilities, and operations. CASI provides the military with capabilities that enhance national security through more effective use of limited resources and improved coordination and partnerships with host communities and stakeholders in the United States and across the globe.

In all efforts, CASI teams strive to measure sustainability innovations against the Triple Bottom Line of mission, environment, and community. In addition, CASI focuses on cost savings, innovation, collaborative solutions, and continuous learning, all of which directly link sustainability to Army Business Transformation and the Army Campaign Plan.

This 2014-2015 Sustainability-Related Publications is the seventh annual CASI publication. Previous annual publications, known as "Work Plans," published from 2008-14, are referenced below, with links provided to the documents (all of which are also located on the CASI website under the "Library" section).

CASI Work Plan Calendar Year 2014, Alan Anderson, Franklin Holcomb, Annette Stumpf, and Elon Zeigler, ERDC/CERL TN-14-1, June 2014, http://acwc.sdp.sirsi.net/client/en U.S./search/asset/1036586

CASI Work Plan Calendar Year 2013, William D. Goran, Michelle Hanson, Elon Zeigler, and Annette Stumpf, ERDC/CERL TN-13-1, February 2013, ERDC/CERL TN-13-1 http://acwc.sdp.sirsi.net/client/search/asset/1025640 https://eko.usace.army.mil/ secure/4BEEA029- -E2E0-0960748272F8F7EF/ERDC-CERL TN-13-1.pdf

CASI Work Plan Calendar Year 2012, William D. Goran, Michelle Hanson, Elon Zeigler, and Annette Stumpf, ERDC/CERL TN-12-1, January 2012, https://eko.usace.army.mil/_secure/4BDCC685-B81D-1CD1-3D958CFDE2DB11C5/2012WorkPlan-13-Jan-FINALsmallfile.pdf

Center for Advancement of Sustainability Innovations: 2011 Work Plan, William Goran, et al., ERDC/CERL TN-11-11, J anuary 2011, https://eko.usace.army.mil/centers/casi/library/?syspage=Documents\&id=263037

Center for Advancement of Sustainability Innovations: 2010 Work Plan, William Goran, et al., ERDC/CERL TN-10-1, April 2010, at either: https://eko.usace.army.mil/ secure/4B7DD77A-C376-36A8-A84FEC6F7A1DC3BE/FY 2010 CASI Work Plan.pdf https://eko.usace.army.mil/centers/casi/library/?syspage=Documents\&id=263155

CASI Work Plan Fiscal Year 2009, William Goran, Annette Stumpf, and Michelle Hanson, ERDC/CERL Special Report 08-21, November 2008, https://eko.usace.army.mil/ secure/4BA5065B-E946-50E120324297E3099A62/Work PlanFINALMay1509 \%282\%29.pdf

Fiscal Year 2007 Annual Report, Center for the Advancement of Sustainability Innovations, William Goran, ERDC/CERL Technical Note (TN-08-02), May 2008, (CASI Work Plan for 2008), http://acwc.sdp.sirsi.net/client/search/asset/1002025 
The purpose of these published Work Plans has been to:

- Provide a framework to capture diverse sustainability activities being conducted by ERDC

- Help various sponsors, partners and stakeholders understand the scope of sustainability activities and expertise that ERDC can offer

- Identify areas where activities can be leveraged for those with similar interests or ongoing investments

- Suggest potential research areas that have been conceived but not yet resourced by potential partners and sponsors

- Enhance dialog and teaming across the different technical focus areas

- Document ERDC sustainability activities

Of special note is the inclusive nature of this "summary of sustainability-related publications," which incorporates descriptions of work related to the theme of sustainability that was conducted under many ERDC programs as well as CASI.

\section{Technology Focus Areas}

One of the key values of CASI is to provide "systems level" expertise to address complex sustainability issues. Installations and communities engage across a wide range of economic, environmental, social, and mission issues that interact in multiple temporal and spatial dimensions. Most of the issues addressed in this document span multiple technology focus areas. The focus areas are simply useful "bins" for planning suites of projects and joining groups of experts. These technology focus areas also indicate the explicit topical areas where CASI has selected teams of experts from within and beyond ERDC. As the sustainability challenges of the U.S. military change, these technology focus areas will also change. Currently, the nine CASI technology focus areas are:

- Anticipating Emerging Issues

- Climate Change

- Sustainable Installations - Net Zero Planning

- Sustainable Energy Solutions

- Sustainable Water \& Waste Resources

- Sustainable Facilities and Infrastructure

- Sustainable Contingency Basing

- Sustainable Natural Infrastructure

- Green Remediation and Reuse

\section{Coordination and Outreach}

\section{Website}

The CASI website is supported by the Engineering Knowledge Online (EKO ${ }^{\circledR}$ ) portal: https://eko.usace.army.mil/centers/casil

The website includes a calendar of events, information on each of the technology focus areas, a library with all available CASI documents and publications, and links to other related sites. Several CASI technology focus areas manage additional web resources supplementing the information on CASI's website, with links from the CASI website.

\section{Marketing Materials}

The CASI brochure and poster are available for download on the CASI website. A CASI display supports marketing activities at conferences, job fairs, and other venues.

\section{Electronic Copies}

Electronic copies of the CASI annual publications are available at: https://eko.usace.army.mil/centers/casi/library/ 


\section{Partnerships}

CASI strives to bring the best team to any specific challenge and this often involves the creation of unique partnerships for each project. CASI has formal and informal partnership arrangements with many academic, industry, and government organizations. Many of the descriptions of these sustainability-related publications highlight these partner organizations.

\section{Projects Represented in This Publications Summary}

The summary is an important tool for CASI to share information and create dialog across multiple stakeholders and organizations. While CASI/Sustainability projects are usually funded by individual sponsors, most projects are also of interest to other sponsors. This summary allows for all sponsors to learn about and follow the progress of any project or area of interest, and where appropriate, to acquire access to project outcomes. In addition, a project sponsored by one organization may help create the dialog necessary to initiate a related or follow-on effort tailored to another organization.

This summary focuses on completed projects. Projects discussed in this report were finished during calendar years 2014-15. While each project is identified within a specific technology focus area, many of these projects are relevant across multiple technology focus areas. The immediate outcomes could be a service (e.g., a new web capability), a forum (e.g., the Interagency Climate Change Impacts and Adaptations forum sessions), a demonstration of a capability, and/or a publication. However, for many CASI/Sustainability initiatives, long-term outcomes are improved understanding of system relationships and tradeoffs, and/or the identification of new pathways to achieve more efficient and sustainable military operations.

\section{CASI Leadership}
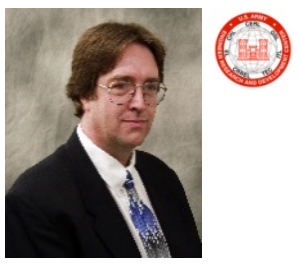

\author{
Alan B. Anderson \\ CASI Director \\ 217-373-7233 \\ Alan.B.Anderson@usace.army.mil
}
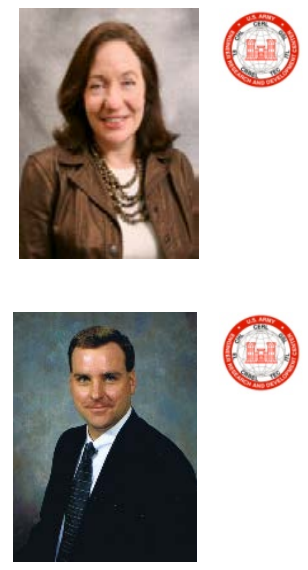

Annette Stumpf Installation Outreach

217-373-4492 Annette.L.Stumpf@usace.army.mil

Patrick N. Deliman CASI Advisory Board 601-634-3623 Patrick.N.Deliman@usace.army.mil
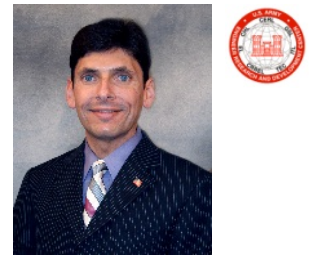

\author{
Franklin H. Holcomb \\ CASI Associate Director \\ 217-373-5864 \\ Franklin.H.Holcomb@usace.army.mil
}
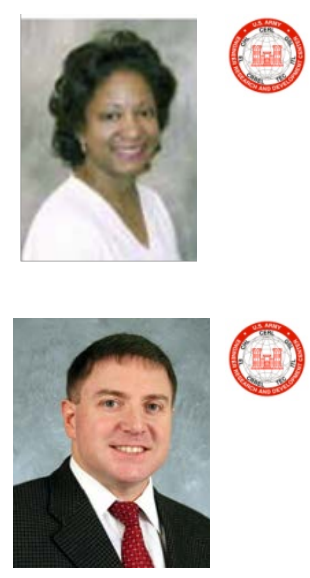

Kevin Knuuti

\author{
Elon Zeigler \\ Knowledge Management \\ Representative \\ 217-373-7256 \\ Elon.P.Zeigler@usace.army.mil
}

\author{
CASI Advisory Board \\ 603-646-4609 \\ Kevin.Knuuti@usace.army.mil
}




\section{In Memoriam}

William (Bill) Goran passed away on 5 March 2015 after a courageous 2-year battle with lymphoma. In recent years, Bill became a national leader in environmental sustainability. He established the Army's Center for Advancement of Sustainability Initiatives (CASI) in 2006 and was its first Director.

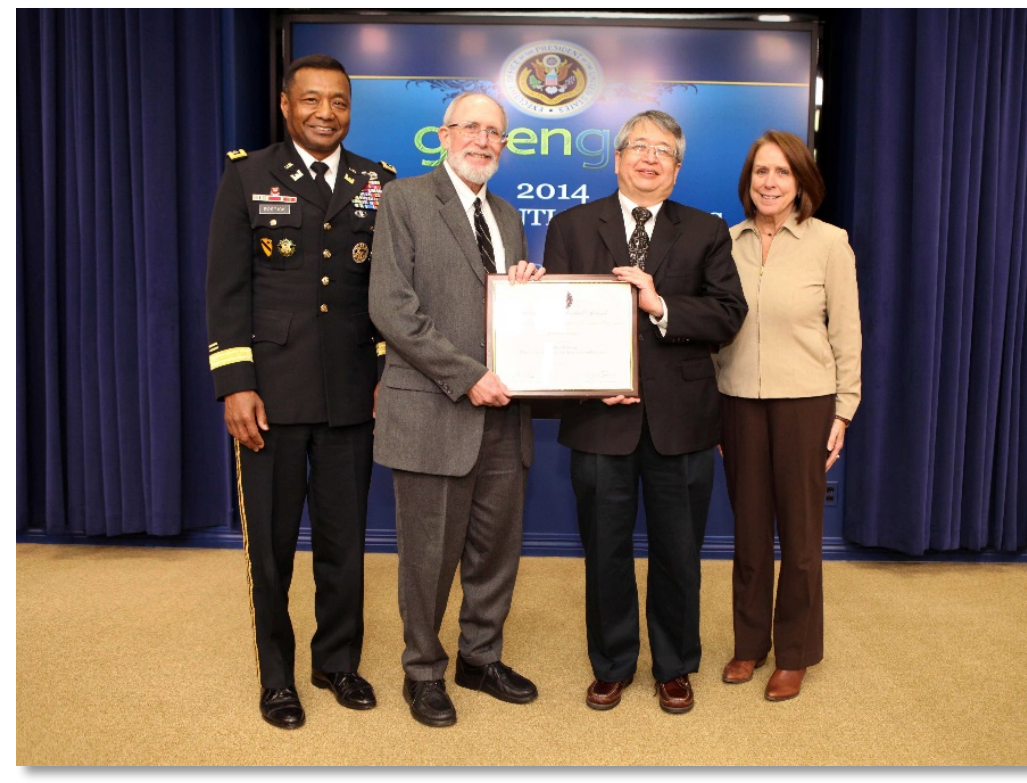

Bill Goran (second from left), receives the 2014 GreenGov Climate Champion Award. Also pictured are Lt. Gen. Thomas P. Bostick, USACE chief of engineers and commanding general, Sam Higuchi of NASA, and Assistant Secretary of the Army (Civil Works) Jo-Ellen Darcy. (Photo by U.S. Army Corps of Engineers).

From the Whitehouse Administration's GreenGov Website:

Bill Goran is universally recognized as a pioneer in helping agencies integrate consideration of the impacts and risks of climate change into their planning processes. Mr. Goran's work dates back to 2007 when he had the foresight to propose a technical focus area on climate change within the Center for the Advancement of Sustainability Innovations at the Engineer Research and Development Center. In 2007, in an effort now considered ahead of its time, he co-founded with NASA the Interagency Forum on Climate Change Impacts and Adaptations that continues to provide a forum for the Federal community to discuss and share technical information and best practices related to impacts of climate change on Federal agencies resources and mission. Mr. Goran has contributed to a number of efforts including development and implementation of climate change adaptation and response plans for organizations such as the Army Institute for Water Resources. The effectiveness of Bill Goran's leadership in the Interagency Forum and his success in ensuring incorporation of climate change consideration into Army climate change adaptation planning are a testament to his leadership and commitment. 


\section{Anticipating Emerging Issues}

This focus area strives to achieve a three-fold purpose, to: (1) engage stakeholders through forums, white papers, publications and other means about emerging issues of concern, (2) interpret how these emerging issues might impact Defense activities and operations, and (3) initiate a dialog about potential courses of action to respond to these issues. The CASI White Paper series is one forum that accomplishes this purpose.

MacAllister, Irene E., Jinelle H. Sperry, and Pamela Bailey. Draft CASI TN.

Identification of Insect-Plant Pollination Networks for a Midwest Installation: Fort McCoy, WI, http:/lacwc.sdp.sirsi.net/client/en_US/search/asset/1049246

Pollinating insects and pollinator dependent plants are critical components of functioning ecosystems, yet for many DoD installations, the identities and relationships between pollinators and plants are unknown. This study demonstrated methods for compiling and analyzing readily available information for insect pollinators and pollination dependent plants for a single installation, Fort McCoy, WI. Although installation documents identified a total of 1470 insect species and 972 plant species were identified on the installation, this work focused on species of conservation concern (nine pollinator insect species and three pollinator-associated plant species). Published information on insect pollinators and pollination dependent plants was then used to conduct a basic plant-pollinator network analyses using free analytical network software (software package R), which revealed that all the plant species of conservation concern are pollinated by several insect pollinator species. However, many pollinator insect species of conservation concern were associated with a limited number of host plant species. The results of this work suggest that analyses that rely on publicly available information provide a useful starting point in determining basic, binary plant-pollinator relationships. Field-collected data, e.g., frequency of pollinator-plant interactions, would be required for a more detailed, robust network analysis.

Results of the insect pollinators bipartite mutualistic network analysis.

Pollinators are indicated with brown boxes and plants species are in green.

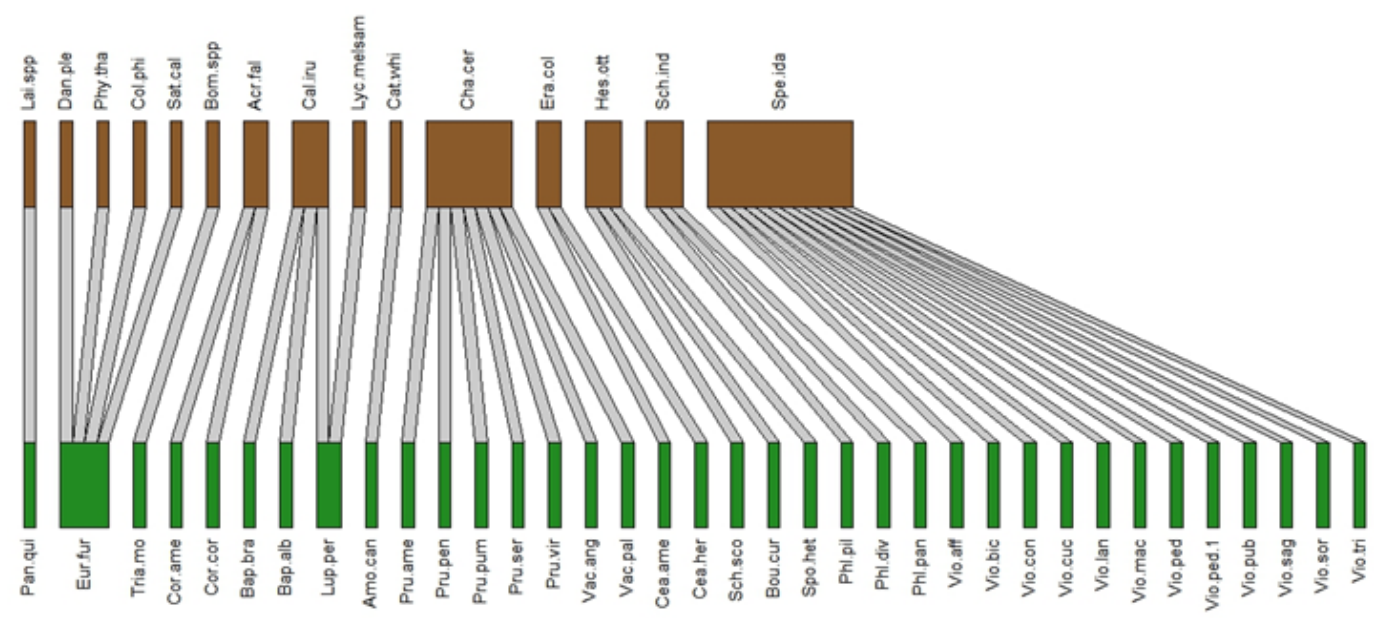


Ping Gong. Draft ERDC/EL TR. Clustered Regularly Interspaced Short Palindromic Repeat/CRISPR-associated protein 9 (CRISPR/Cas9)-based Gene Drives for Invasive Species Management on Military Lands.

Invasive species are increasingly recognized as serious social, economic, and ecological problems. Applications of genetic engineering-based technologies to the control of invasive species are emerging as an important area of innovation in this regard. Recently, gene drive (i.e., a mechanism to spread the desired genes and associated traits into the target population) has emerged as a promising genetic biocontrol strategy to combat invasive species like carp and mosquitos. Unlike existing

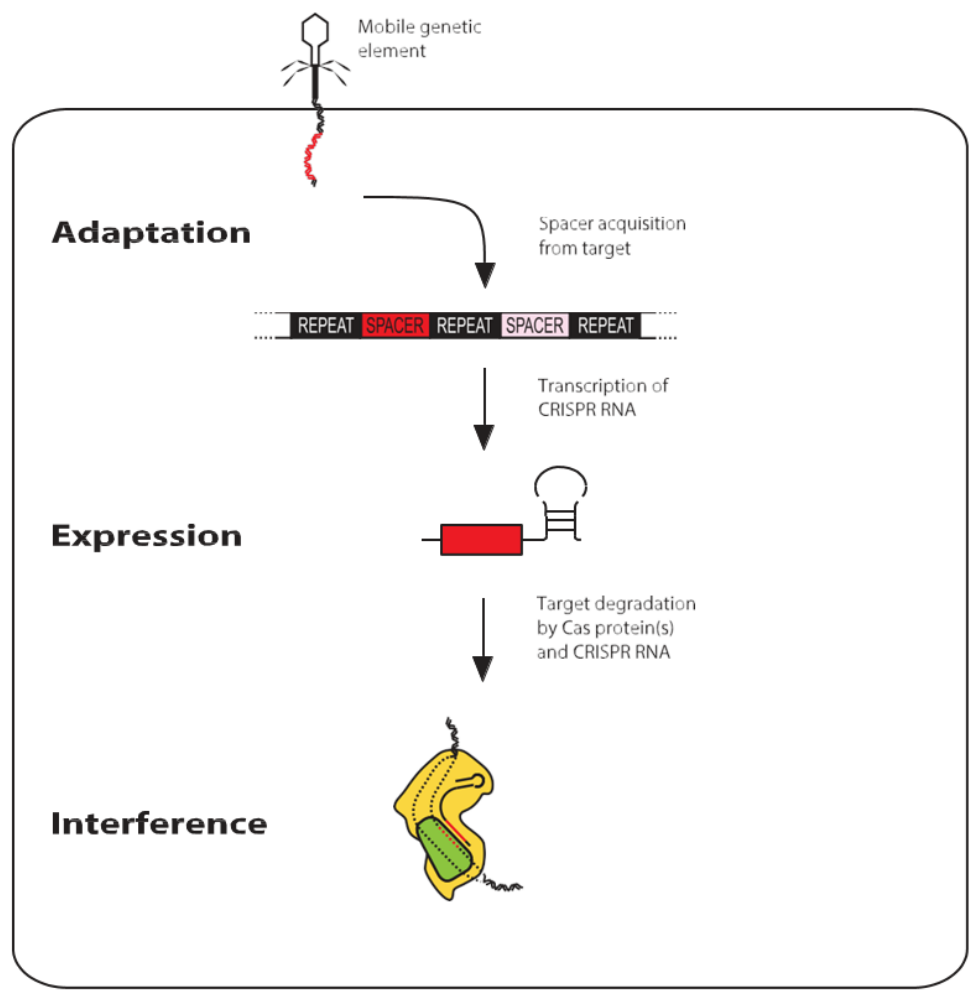

The key steps of CRISPR-Cas immunity technologies based on homing endonucle-

ases, zinc finger nucleases, and transcription activator-like effector nucleases, which depend on the cumbersome custom-making of new proteins for each deoxyribonucleic acid (DNA) target, the CRISPR system uses ribonucleic acid (RNA) as its DNA-homing mechanism, which makes it low cost, high efficiency, and easy to implement, and which also dramatically shortens the design-build-test cycle for gene drive development. While relying on exactly the same copying/homing mechanism as naturally existing homing endonucleases, CRISPR/Cas9-mediated gene drives can sweep a "deleterious" gene through a population exponentially faster than normal Mendelian inheritance, thus suppressing or eradicating the target invasive species. CRISPR/Cas9-based gene drives are poised to become a self-sustaining, highly efficient, environmentally benign, and cost-effective alternative for invasive species control. Biosafety, ecological risks, regulations, public perceptions, and limitations surrounding the development and release of CRISPR/Cas9-based gene drives are also discussed.

\section{Dawn A. Morrison, Colin D. Wood, Timothy K. Perkins, et al. Draft ERDC/CERL TR. Extreme} Environment Basing: Contingency Basing in Dense Urban and Megacity Environments.

The U.S. military may be required to operate in dense urban and megacity environments, which may pose significant challenges for contingency basing. This work reviews and analyzes the potential disconnect between existing doctrine, standard operating procedures, and the human geographic reality of dense urban environments and megacities as concerns contingency basing. The work: (1) characterizes 41 projected megacities using the Army Chief of Staff's Strategic Study Group's megacity typology, (2) performs crosswalk analysis between this characterization and existing contingency basing doctrine, (3) details doctrinal gaps, specifically those pertaining to site selection, logistics, and security, and (4) recommends future research to alleviate those gaps. 
Dense urban environments, top-left, clockwise: favelas of Rio de Janeiro; traffic in Dhaka, Bangladesh; residential area of downtown Hong Kong; Slums surrounding the Mumbai International Airport.
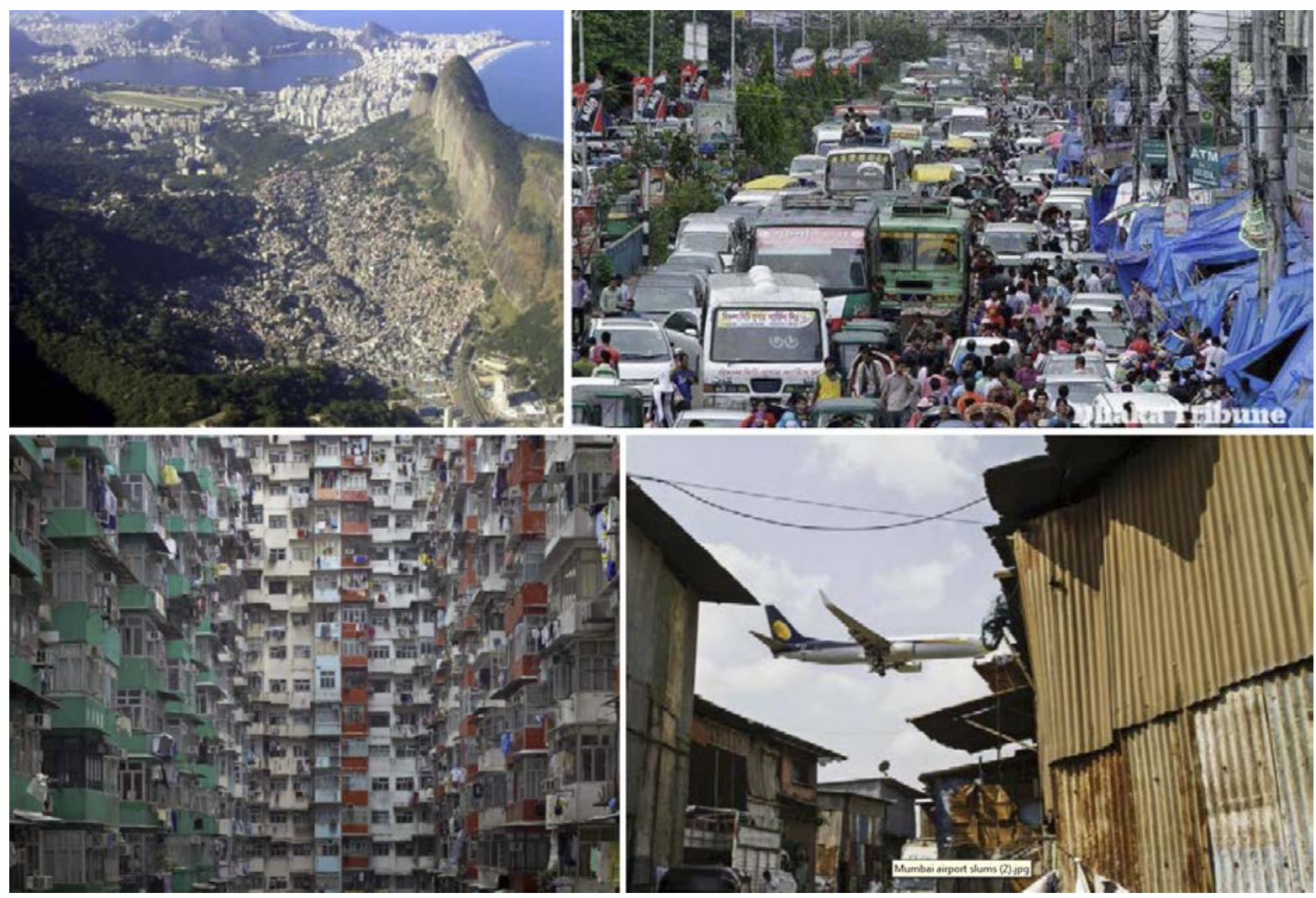

David Delaney, Patrick Guertin, Michael White, et al. 2016. ERDC-CERL TN-16-1.

Assessment of Small Arms Munitions Impacts on Natural Infrastructure in Sensitive Downrange Areas on Military Installations, http:/lacwc.sdp.sirsi.net/client/en_US/search/asset/1048789

Large areas of high-quality terrestrial natural infrastructure exist downrange of small-arms training ranges on DoD installations. Live-fire training has caused concern to regulatory entities due to the potential impacts on natural resources, and to safety concerns expressed by adjoining land owners. This paper investigated whether there are reliable documented methods to quantify the number of bullets that escape the cantonment berm and ultimately fall down range via queries among Natural Resource peers and a technology review to document existing methods that address bullet fate on ranges. Responses to the inquiries indicate that Natural Resource personnel on military facilities or other state or federal agencies do not have adequate tools or guidance to address the potential issue of smalls arms munition impacts within sensitive downrange areas. It was recommended that military installations further examine acoustical techniques for quantifying bullet overshot and ricochets into sensiDifferent types of tree damage caused by bullet strikes on Fort Benning and Fort Stewart, GA: small scars (A), large cambium cuts (B), bark

bullet strikes (C), nodules (D), and broken branches, leader or stems (E).

tive wildlife areas. Acoustical techniques offer a viable method for quantifying bullet intrusions into downrange areas. However, a more comprehensive testing procedure must be tested to gauge the effectiveness of this technique at bermed and unbermed ranges under different field conditions. 
Victor F. Medina. Richard J. Scholze, Scott A. Waisner, et al. ERDC SR-15-2, Energy and Resource Recovery from Wastewater Treatment: State of the Art and Potential Application for the Army and the DoD, http:/lacwc.sdp.sirsi.net/client/en_US/search/asset/1043946

This report summarizes a study to assess energy and resource recovery from wastewater treatment and assess short- and long-term opportunities and impacts for the Army and DoD in general. The organic material in wastewater contains inherent energy. The challenge is concentrating and recovering this energy. Several methods are available; of these, anaerobic digestion (either of the sludge, or directly applied to the wastewater using an Upflow Anaerobic Sludge Blanket or a similar reactor) is the most advanced and can be readily applied to existing military installations or to contingency operations. Recovery of chemical products

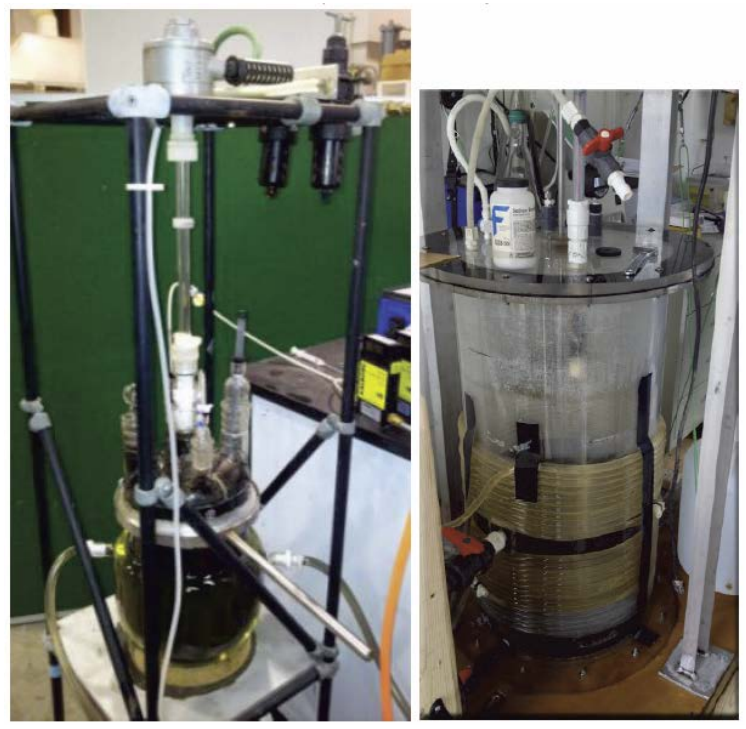

Laboratory and pilot reactors used to study anaerobic digestion for treating Forward Operating Base wastes. is another option for wastewater treatment. The most commonly recovered products are nutrients, in the form of nitrogen (N) and phosphorus (P). The simplest way is to recycle the collected and digested biosolids (sludges), either for direct soil application or by incorporation into compost. Resource recovery from wastewater may eventually include biopolymers that could make bioplastics or valuable nanometals that are increasingly found in consumer products. Many of the energy recovery technologies and most of the resource recovery approaches (beyond simple biosolids recovery) require large-scale operations to be economically viable at this time.

Wastewater treatment facilities that serve Army and other DoD installations tend to be relatively small, limiting the application of many approaches that might be practicable in the civilian sector. ERDC should focus research on technologies that could be economically applied to smaller treatment plants on the order of 3 to $10 \mathrm{mgd}$. 


\section{Climate Change}

Climate change is one future trend that will impact our national security. Rising global temperatures, changing precipitation patterns, climbing sea levels, and more extreme weather events will intensify the challenges of global instability, hunger, poverty, and conflict. Climate change is seen as a "threat multiplier" because it has the potential to exacerbate many of the challenges facing the nation today - from infectious disease to terrorism. A changing climate will have real impacts on our military and on the way it executes its missions, on the way it is called upon to support civil authorities and to provide humanitarian assistance and disaster relief in the face of more frequent and more intense natural disasters.

This focus area addresses the challenges of changing climatic and related conditions. Challenges include those associated with facilities, lands, and operations, and the stressors, posed by changing climatic conditions, on regional and national stability across the globe. Activities in this focus area involve several partnerships with other agencies and nations.

Juliana M. Wilhoit, Grace M. Díaz-Estrada, James P. Miller, et al. Draft ERDC/CERL TR. Water Stress Projection Modeling.

U.S. Army stationing is a constant multiscale process. Large scale stationing, which is identified with strategic realignments, requires some level of modeling to determine whether the movement of tactical equipment and large numbers of personnel is both economical and continues to meet future long-term strategic requirements. This work explored how climate change implications on water resources may affect military installations in the future, and used that information to outline the WAter Stress Projection (WASP) model, which serves as a decision support system tool that integrates water stressors resulting from global climate change and regional growth to assess the availability of water to an installation in the future. WASP is a tool that provides a scalable solution to incorporate water into the U.S. Army stationing process and to generate a maximum number of personnel at an installation, which can be used as an Optimal Stationing of Army Forces (OSAF) constraint. To test the impact of climate change on the U.S. Army, the model was applied to five case study installations located across the continental United States in a variety of climate zones.

Magnitude of annual floods from the 1920s to 2008 shown with magnitude (size) and direction (color).

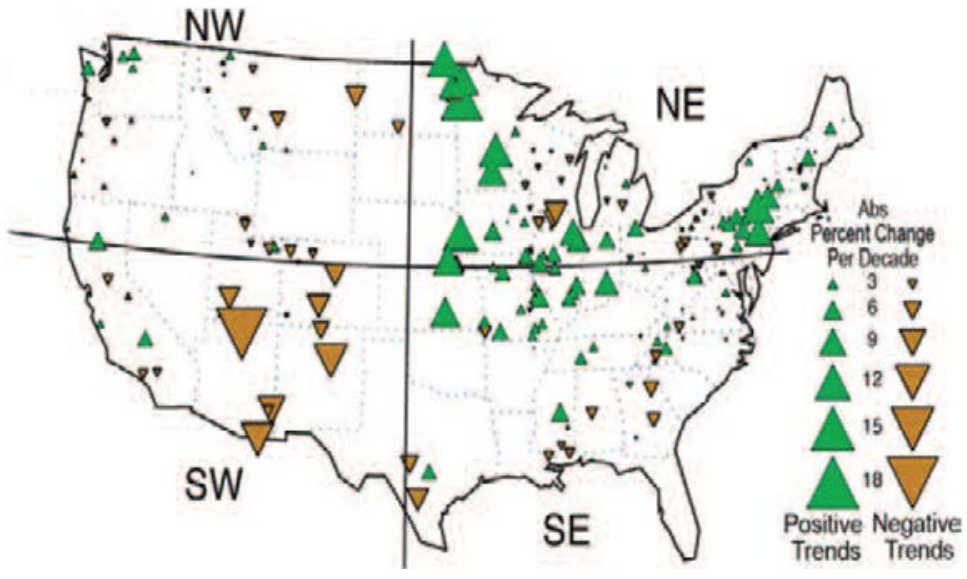

James Miller, Juliana Wilhoit, Kristina Tranel, et al. ERDC/CERL TR-15-24.

Integrated Climate Assessment for Army Enterprise Planning,

http:/lacwc.sdp.sirsi.net/client/en US/search/asset/1045989

In the decades to come, climate change is expected to impact the Army's costs, its abilities to train and maintain the force, and its mission capabilities. These potential climate change impacts need to be considered in the Army's stationing/restationing analysis process to ensure that future decisions concerning locating and relocating Army Forces are optimized to minimize costs while maintaining the ability to effectively train, maintain, and deploy forces. 
This study was performed to identify and recommend possible improvements to the Army's stationing/restationing analysis process, specifically, by including climate factors in the stationing analysis process to enable a more complete modeling and cost analysis.

John W. Weatherly and Mattson A. Rosenbaum. Draft ERDC/CRREL TR. Use of Heat and Fire-Risk Indices to Project Local Climate Impacts on Selected Army Installations.

Climate change is expected to produce increasing impacts on training and infrastructure on Army installations in the coming decades. Planning to enable Army installations to adapt to the changing climate can be supported by suitable estimates of climate impacts over timeframes suitable for strategic plans. This work computed the impacts of future climate change on available training days for seven sample Army installations using projections of temperature and precipitation from global climate models. The number of days with heat-related training restrictions and fire risk from live-fire training were calculated using observed weather station data and climate model projections for several future climate scenarios. For these installations, increased temperatures in time periods centered on 2030,2050 , and 2090 result in a greater number of days with heat categories above 84 and $90^{\circ} \mathrm{F}\left(28.9\right.$ and $\left.32.2^{\circ} \mathrm{C}\right)$ and with high fire risk. The climate impact on heat-affected training days is greater in the U.S. Southeast, where high humidity also contributes most to the heat index. The impact on the fire risk for training is greater in the U.S. Southwest, where the low precipitation and high temperatures contribute to the high drought index. Future work will include additional installations and climate variables.

\section{Michelle E. Swearingen, Andrew Fulton, Wade Wall, et al. Draft ERDC/CERL TR. Effects of Climate Change and Urban Development on Army Training Capabilities: Firing Ranges and Maneuver Areas.}

Army stationing analyses have historically been conducted under the assumption that most conditions at and around installations will generally remain static. Previous optimal stationing analyses have resulted in substantial costs associated with moving units, constructing buildings and roads, and local investments in the development of off-post housing, shopping facilities, eating, and other businesses that provide quality of life for soldiers and their families. In reality, the capacity of the natural, social, and built infrastructure changes over time, and this non-stationarity should be considered in stationing analyses to: (1) avoid premature abandonment of expensive buildings and associated infrastructure, and (2) avoid costly realignments to locations where capacity is being adversely affected by change. This report documents efforts completed in FY14 that began to investigate how potential changes associated with climate and urban development might affect the ability of Army installations to continue to conduct training on firing ranges and in maneuver areas.
Ten-mile buffer with census tracts overlaid.

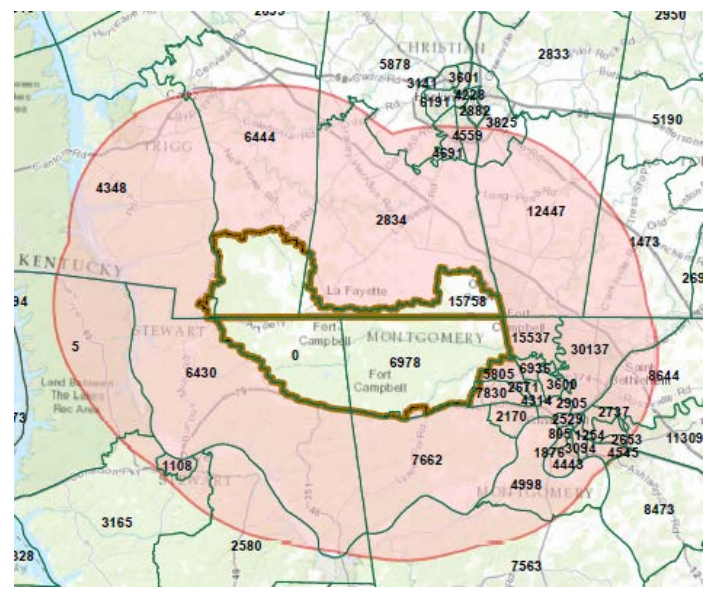


Robert C. Lozar and James D. Westervelt. ERDC/CERL TR-14-17. Application of Maxent Multivariate Analysis to Define Climate-Change Effects on Species Distributions and Changes, http://acwc.sdp.sirsi.net/client/en_U.S./search/asset/1043707 ERDC/CERL TR-14-17

Army installation managers and planners have limited sources of scientifically reliable information that can be used to examine potential climate impacts on local flora and fauna. The present work evaluated the viability and versatility of applying statistical multivariate analysis to define the current and projected future range probability for species of interest to Army land managers. A software program called Maxent was used to perform range-extent analyses for two animal species of interest to Army land managers: the Red-Cockaded Woodpecker (RCW) and the common musk turtle. The technology was used to determine how climate change might affect species thresholds of survival at Army installations. The software data input requirements and output capabilities are described. The analytical methodology applied to the study of both species is discussed in detail, and validation of results is addressed.

The authors conclude that Maxent analyses can provide impartial, data-based results that reflect scientific consensus on related climate-change issues while avoiding emphasis on the extremes of scientifically collected data. Analysis results indicate that climate change will alter RCW habitat threshold values on some installations beyond the point where Army-managed mitigation is possible. In contrast, musk turtle habitat will Maxent probability output map for the musk turtle ( Savannah River Laboratory sample locations displayed as dots and the traditional range as a dotted line increase at least until 2025.

Juliana Wilhoit, Scott Tweddale, Matt Hohmann, et al. Draft ERDC/CERL TR. Effects of Climate Change, Urban Development, and Threatened and Endangered Species Management on Army Training Capabilities.

Army stationing analyses have historically been conducted under the assumption that conditions at and around installations will remain static. In reality, the natural, social, and built infrastructure changes over time, and this nonstationarity should be considered in stationing analyses to ensure continuation of each installation's mission. This work documents efforts completed in Fiscal Year 2015 that addressed the temporal aspects of population growth and its potential for negatively impacting an installation's training areas, and the potential impact of currently listed and species at risk of being listed to the endangered species list. A modified method for estimating population impact and a new method for estimating the impact of listed and at-risk species are described.
Map of urban development in relation to distance from ranges at Fort A.P. Hill.

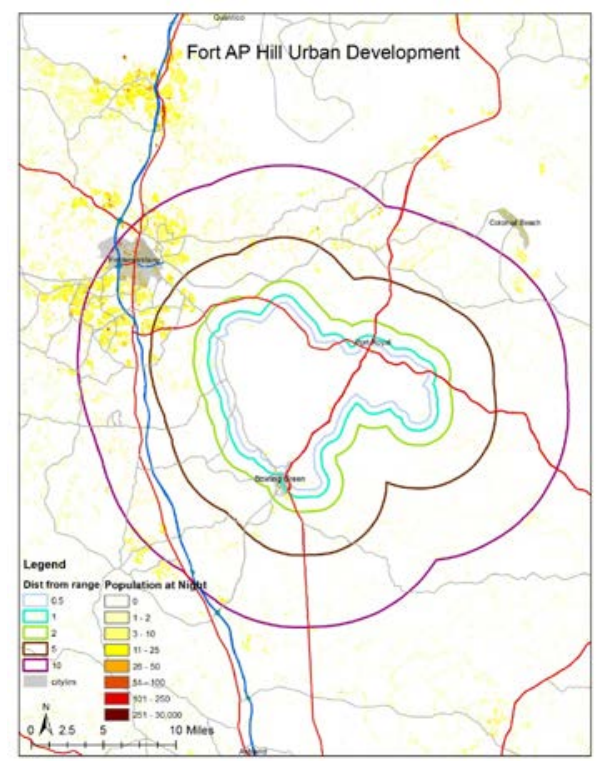


Robert C. Lozar and James D. Westervelt. ERDC/CERL TR-15-2. Multivariate Bioclimatic Ecosytem Change Approaches,

http:/lacwc.sdp.sirsi.net/client/en_US/search/asset/1042066

Changes in climatic parameters are important in that they affect the military's ability to perform its national defense mission and to manage military lands. The military must have the ability to predict climatic changes on specific installations. To support this need, this research tested and

Bio12 annual precipitation exhibits the Benning "climatic hole."

The darker blue represents locally lower precipitation.

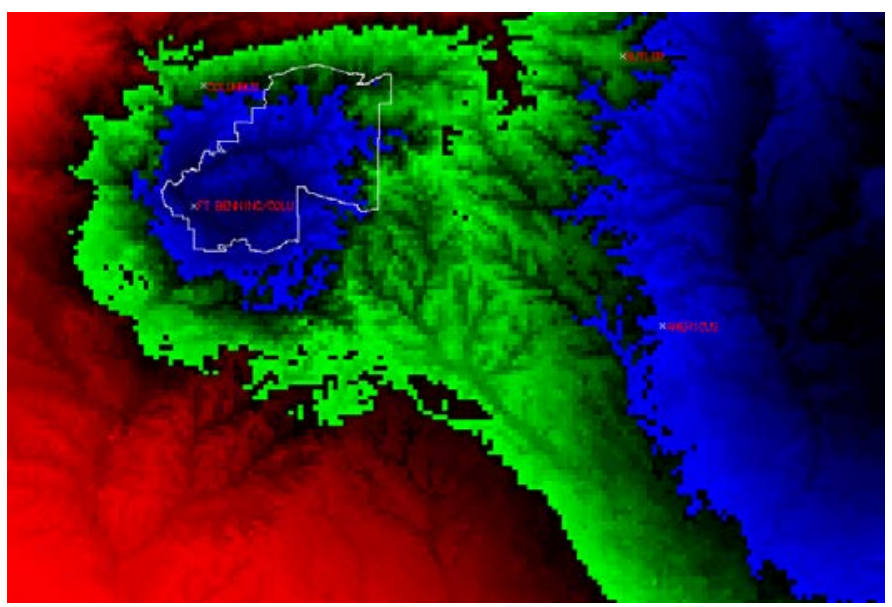

evaluated the application of six multivariate approach techniques to predict climatic changes on a specific Army installation, Fort Benning, GA. The six approaches were tested for their ability to identify where anticipated future conditions might be found today using a set of 19 bioclimatic parameters derived from climate change data. The evaluation found that the Primarily Analogous Multivariate approach developed during this research clearly distinguished itself from the other five approaches in that it successfully determined future climatic factors at the installation, as well as at the sub-installation level using the currently available climatic data.

Janet P. Hardy. 2015. ERDC/CRREL SR-15-1. Indicators of Physical and Biological Trends around the McMurdo Station: A Literature Review, http:llacwc.sdp.sirsi.net/client/search/asset/1043447

The U.S. Antarctic Program (USAP) is managed by the National Science Foundation, Division of Polar Programs (NSF-PLR), which has the responsibility for all logistics and operations related to U.S. scientific research in Antarctica and aboard ships in the Southern Ocean. For years, scientific literature has focused on global environmental change and, in particular, on the accelerated change occurring, and predicted to occur, in the Polar Regions.

This report summarizes documented changes that have occurred in Antarctica, with a focus on the Ross Sea region, as well as projections of environmental change expected to occur in the next 100 years. Many of the observed changes in the Ross Sea region since 1960, such as increased air and soil temperature, decreased glacial extent, and sea level rise, are consistent with a warming climate; however, the observed increase in sea-ice extent does not fit an expected pattern and is explained by a shift in circumpolar circulation. Models predict the observed changes to continue over the next 100 years, except that they anticipate the sea-ice extent in the Ross Sea region to decrease significantly. This report also presents potential implications of these changes for USAP operations and logistics, primarily in response to the reduced sea-ice extent and higher air and soil temperatures.
Trend in fractional sea-ice cover per decade as calculated from 1979 to 2012

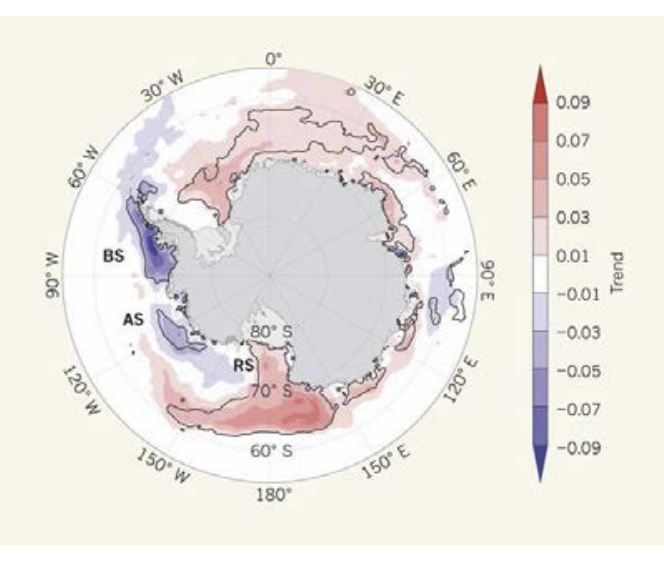


Jeanne M. Roningen and John B. Eylander. 2014. ERDC/CRREL TR-14-5. Socio-economic Effects of Drought in the Horn of Africa: Population Movements, Livelihoods, and Market Prices,

http:/lacwc.sdp.sirsi.net/client/search/asset/1034461

In recent years, the intelligence and defense communities have indicated interest in understanding the potential relationships between anomalous climate events and socio-economic consequences outside of the United States that could have implications for U.S. national security. This research evaluates potential linkages between retrospective climate analyses and empirical socio-economic datasets in Somalia and Kenya surrounding the 2011 drought in the Horn of Africa. Subnational-level data on internally displaced persons in Somalia from 2008-2012 were used to correlate drought-related population movements to climatemodel-derived moisture indices. The analysis was expanded to account for livelihood zones and to investigate the predictive capabilities of linear models for observed population movements. Additional analyses investigated market price response to drought and market connectivity and explored the use of census data on household water infrastructure to assess drought vulnerability of specific communities. Results suggest that drought-induced migration response occurred with low but significant correlations across a broad range of medium- to longterm ( 6 months to 4 years) standardized drought indices, but was limited largely to the geographic area in southern Somalia subject to a confluence of three factors: al-Shabaab governance during the 2011 drought, associated legal and operational impediments to aid delivery, and non-arid seasonality patterns.

Production and market flow map for maize.

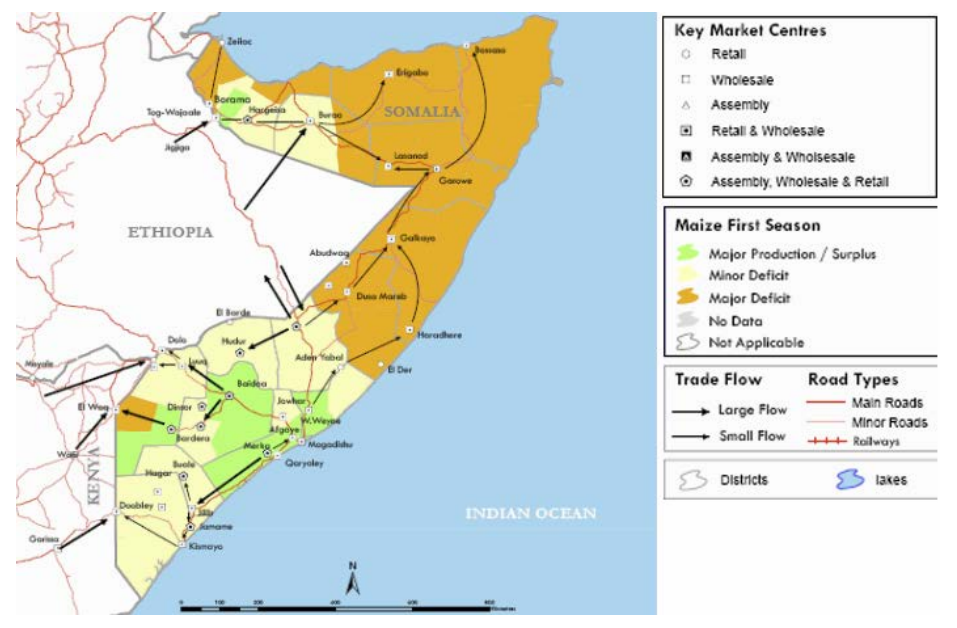




\section{Sustainable Installations - Net-Zero Planning}

Net Zero is a strategy that strives to bring the overall consumption of resources on installations down to an effective rate of zero. The Army's vision is to appropriately manage our natural resources with a goal of achieving Net Zero Installations. Today, the Army faces significant threats to our energy and water supply requirements both at home and abroad. Addressing energy security and sustainability is operationally necessary, financially prudent, and mission essential. The Net Zero concept encompasses not only Energy, but Water and Waste as well. The Army is investing in its installations to improve efficiencies in energy, water and waste for the benefit of the current and future force, and of the nation.

Alexander M. Zhivov, Michael. P. Case, Richard. Liesen, et al. ERDC/CERL TR-15-28 Demonstration of The Energy Component of The Installation Master Plan Using The Net Zero Planner, http:/lacwc.sdp.sirsi.net/client/en US/search/asset/1049607

This work demonstrated the energy master planning (EMP) concept and the ERDC-developed automated Net Zero Planner tool (NZP) at two DoD installations: U.S. Military Academy, West Point and Portsmouth Navy Shipyard. The NZP Tool incorporates the concept and various automated modules to integrate optimization across buildings, distribution, and generation systems. Results demonstrated that use of the NZP Tool reduces the time required for the analysis and the analysis cost to $\sim 35 \%$ of that required by the alternative current best practice. Lessons learned from the project were used to make many user interface changes throughout the program to facilitate the process, ease data entry, and help determine the information required to produce useful, relevant output reports. Funding for this demonstration was provided by the Environmental Security Technology Certification Program (ESTCP).

Examples of community boundaries: a- defined by building clusters; b- defined by physical limitations.

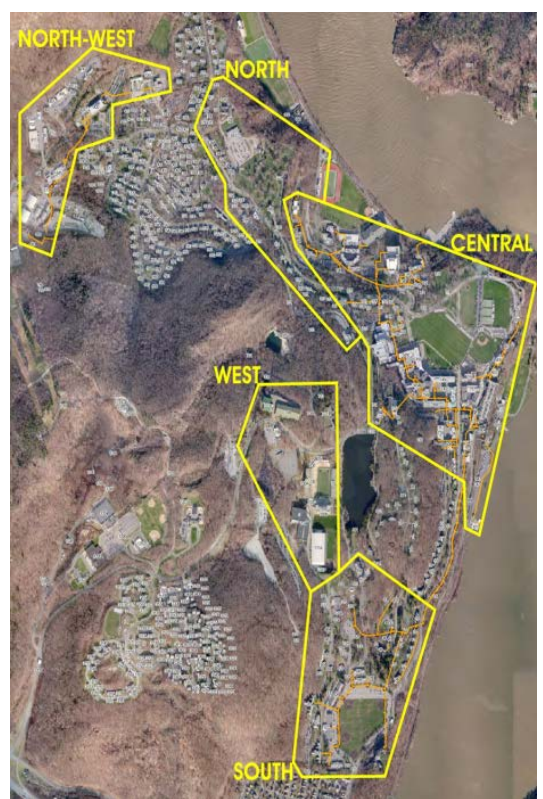

a.

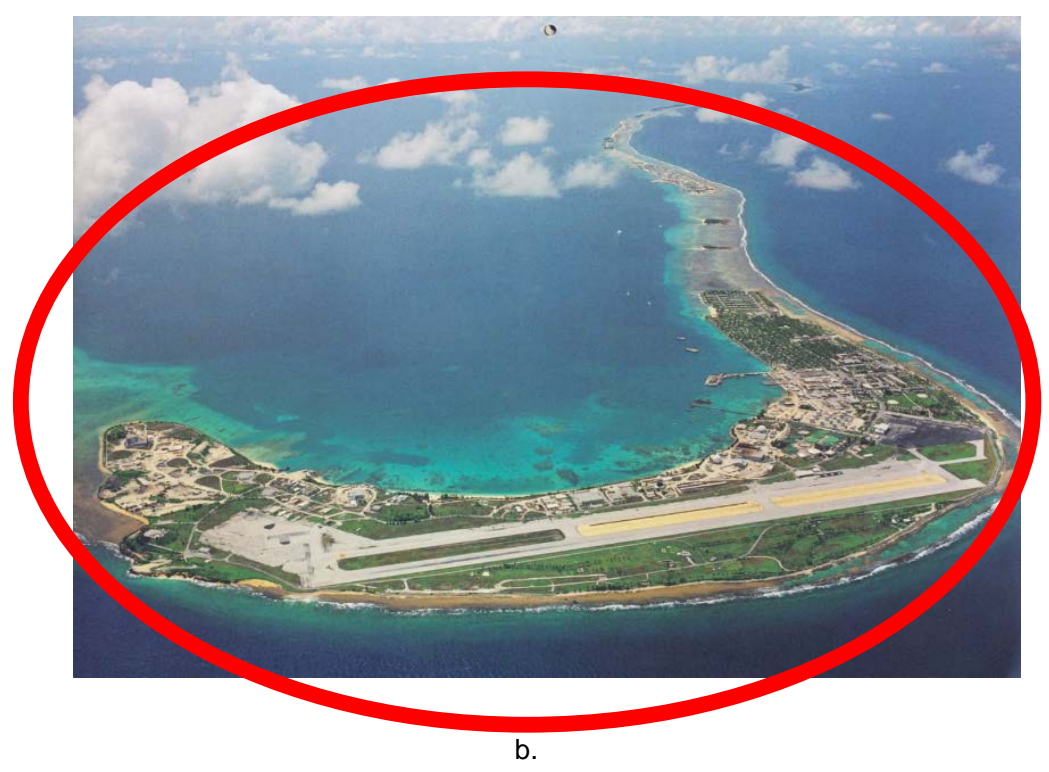


Annette L. Stumpf, Michael P. Case, Matthew M. Swanson, et al. ERDC/CERL SR-14-11. Net Zero Energy Water Waste Portfolio for Fort Leonard Wood.

http:/lacwc.sdp.sirsi.net/client/en_U.S./search/asset/1042166 ERDC/CERL SR-14-11

The Army has focused its organizational sustainability on the development of Net Zero waste, energy, and water at its installations. A Net Zero energy installation is an installation that produces as much energy on site as it uses, over the course of a year. As part of its strategic sustainability vision, Fort Leonard Wood seeks to meet Army Net Zero objectives. This project was undertaken to develop an integrated portfolio of cost-effective and mission-appropriate strategies, approaches, and technologies to help Fort Leonard Wood implement its Net Zero strategic vision for energy, water, and waste.

ERDC-CERL helped Fort Leonard Wood identify and evaluate strategies, methods, and technologies to support Army Net Zero objectives. ERDCCERL performed assessments to baseline energy, water, and waste systems at Fort Leonard Wood. Because these systems are highly interrelated, they were best evaluated concurrently and optimized in an integrated effort. Energy, water, and waste teams estimated changes in requirements, population, energy and water use, and waste generation over a 25-year time period. Each team then established alternatives to show how improved practices, sustainable development, and high performance buildings could reduce waste generation, energy, and water use. The information provided should help Fort Leonard Wood decision-makers compare and evaluate feasible options to identify its best long-term profile that will keep its resource use costs low and provide secure energy with a decreased impact on natural resources.

\section{Michael P. Case. Draft ESTCP Report. Demonstrate Energy Component of The Installation Master Plan Using "Net Zero Energy Installation Tool".}

Federal government agencies are required by law to eliminate fossil fuel use in new and renovated facilities by 2030 and to reduce overall facility energy usage by $30 \%$ by 2015 . U.S. Army policy is to achieve eight net zero energy installations by 2020,25 net zero energy installations by 2030 and for all installations to achieve net zero energy status by 2058 . The U.S. Navy is selecting several installations to achieve net zero energy goals as well. ERDC has developed an energy optimization concept and the Net Zero Energy Installations (NZEI) Tool to support DoD energy policy by minimizing energy use at the building level, improving the efficiency of energy generation and distribution, and using energy from renewable sources to balance fossil-generated energy to achieve a net zero fossil energy status.

In 2012, ERDC was awarded an ESTCP project to demonstrate this concept and tool at two defense installations, the U.S. Military Academy at West Point, NY and the Portsmouth Naval Shipyard, Kittery, ME. The project objective is to demonstrate that the ERDC NZEl concept and tool enables a streamlined energy planning process that will develop a roadmap to meet or exceed installation energy framing goals at the lowest lifecycle cost. The criteria for success include meeting or exceeding U.S. Energy Independence and Security Act of 2007 (EISA) criteria for energy intensity, meeting energy security requirements at a lower cost, and controlling electrical capacity growth requirements. Installation energy goals may also include achievement of a net zero energy installation. 


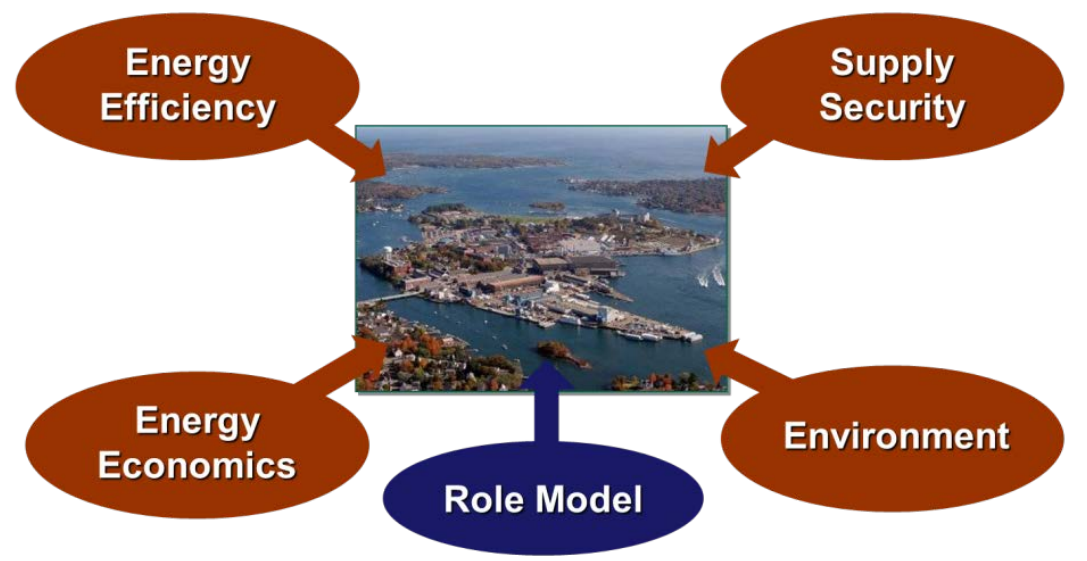

Stephen D. Cosper. ERDC/CERL TR-15-21. Considerations for Net-Zero Waste Installations, http:/lacwc.sdp.sirsi.net/client/en_US/search/asset/1045912

Today's Army faces significant threats to energy and water supply requirements both home and abroad. Addressing energy/water security and sustainability is essential to mission accomplishment. The Army's goal is to manage "net zero installations," i.e., installations that operate not only on the basis of net zero energy, but net zero water and waste as well. A net zero waste installation reduces, reuses, and recovers waste streams, converting them to resource values with zero landfill over the course of a year. This work outlines a plan for ERDC researchers to support the Army NZI vision by developing an NZI-Optimization tool that includes energy and water tracking and optimization features. This preliminary stage of work was undertaken to characterize Municipal Solid Waste (MSW), and describe the processes and technologies that may be integrated to support a Net-Zero Water (NZW) installation.

Example schematic of an MSW incinerator with energy recovery and air pollution control.

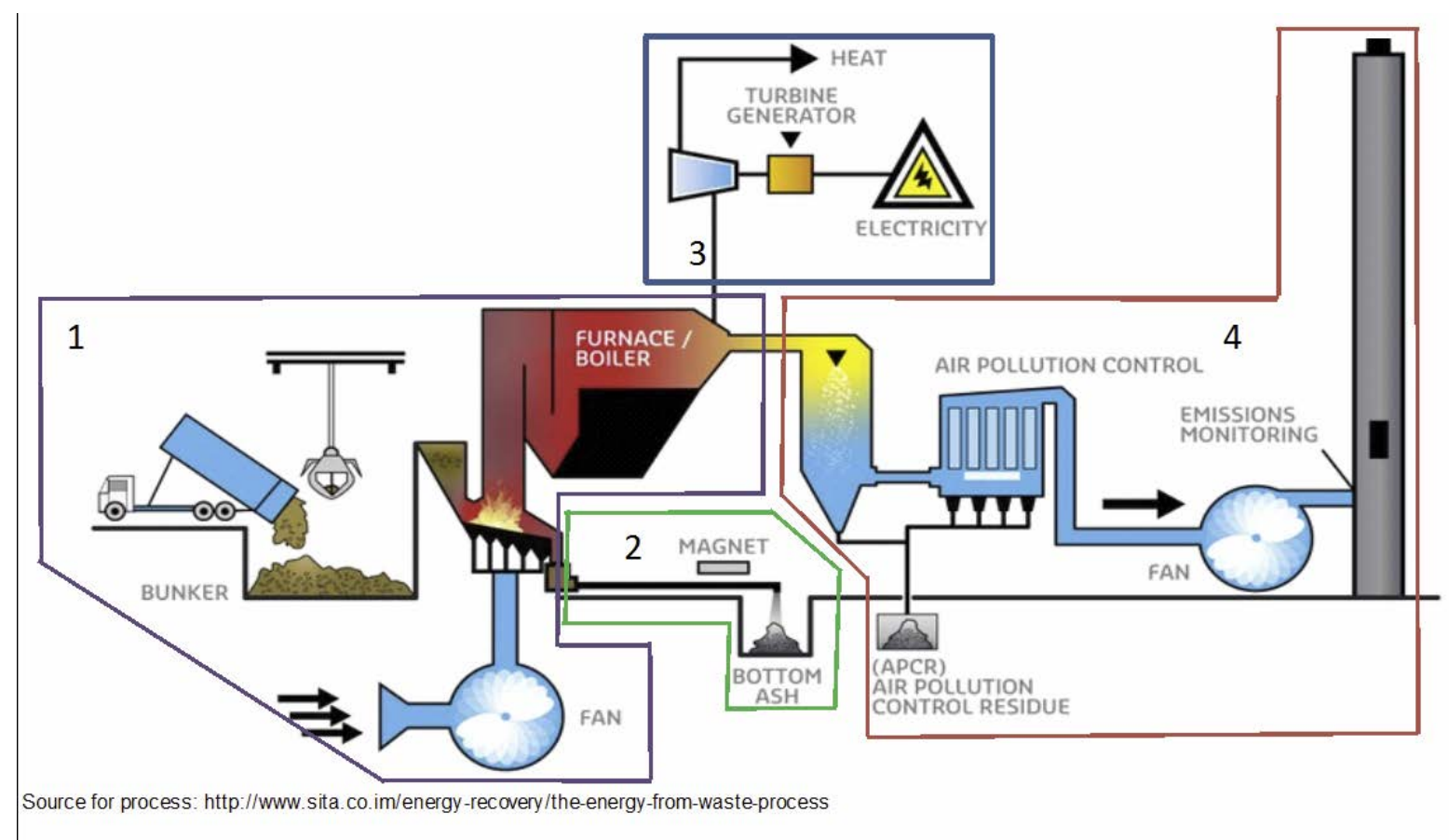




\section{Sustainable Energy Solutions}

DoD has established challenging goals to increase energy efficiency and reduce greenhouse gas (GHG) emissions of their installations in all five services with an ultimate goal of Net Zero Energy (NZE) installations. From a military capability systems support perspective, power and energy are critical to sustainability. They are a consideration in many facets of military operations. The purpose of this technology focus area is to identify the sustainability needs associated with integration of power and energy into military missions.

Natalie R. Myers, Dick L. Gebhart, and Matthew D. Hiett. ERDC/CERL TR-14-32. Biofuel Production: Considerations for USACE Civil Works Business Lines,

http:/lacwc.sdp.sirsi.net/client/en_U.S./search/asset/1041140

EISA has set goals for renewable fuels standards (RFS) that include the production of 36 billion gallons of biofuels by 2022 , of which 21 billion gallons will be derived from non-corn sources. To meet the congressionally mandated bioenergy goals, the evolving bioenergy industry in the United States must be efficient, reliable, and sustainable. The nation and the U.S. Army have a need to review the potential for feedstock-based biofuel production to meet national biofuel energy mandates.

Because it manages large areas of land, the U.S. Army is gaining national appeal for providing cellulosic feedstock to an emerging biofuels industry. Although not currently engaged, the Army and its directorates are investigating how biofuel production might impact the future viability of their mission and operations. A group of environmental specialists at the ERDC-CERL have enhanced the Sustainable Installation Regional Resource Assessment (SIRRA) with a Biofuel Application as a process for characterizing military land regions based on a set of indicators that are then grouped into a range of issues that may affect military installations and their locality. The indicator framework presented in this document characterizes regional aspects of biofuel production, which is intended to Example SIRRA Biofuel Application map provide a heightened awareness of how biofuel production might address various long-term issues and threats to mission sustainment.

\section{Elizabeth J. Gao, Jignesh Patel, Veera M. Boddu, et al. ERDC/CERL TR-15-23. Simulated Aging and Characterization of Phase Change Materials for Thermal Management of Building Envelopes, http:/lacwc.sdp.sirsi.net/client/en US/search/asset/1045871}

Because phase change materials (PCMs) can absorb or release heat when they undergo phase changes (solid to liquid, liquid to solid, or solid to gas), they are considered especially promising candidates for use in heating and cooling applications for building envelopes. This work investigated the stability of four commercially available PCMs, and developed an accelerated testing protocol to simulate the long-term performance of PCMs in an operational scenario. The selected PCM s were subjected to up to 5,400 cycles of thermal cycling at 90 
minutes per cycle, over wide temperature ranges to simulate 20 years of use in building envelopes. At 3-4 week time intervals, the samples were taken from the thermal cycling chamber, analyzed, and the data obtained were compared to baseline (pre-cycling data). Thermal cycling in conjunction with Differential Scanning Calorimetry (DSC), Scanning Electron Microscope (SEM), and Thermogravimetric Analysis (TGA) appears to be a valid way to predict the long-term physical and thermal changes in a PCM samples based on short term testing, and the 90-minute testing cycle appears to be adequate for the purpose of quickly simulating daily phase changes that the PCM would experience in operational environments.

Baseline latent heat values and freezing and melting transition temperatures were generally in accordance with the manufacturer's stated values although all PCM materials evaluated tended to lose some latent heat storage capacity as they underwent thermal cycling.

SEM images of Micro-encapsulated PCM pellets (Microtek 18D): (a) before thermal cycling, (b) after 1680 cycles (6.2 years), (c) after 3696 cycles (13.7 years), and (d) after 5400 cycles (20 years).
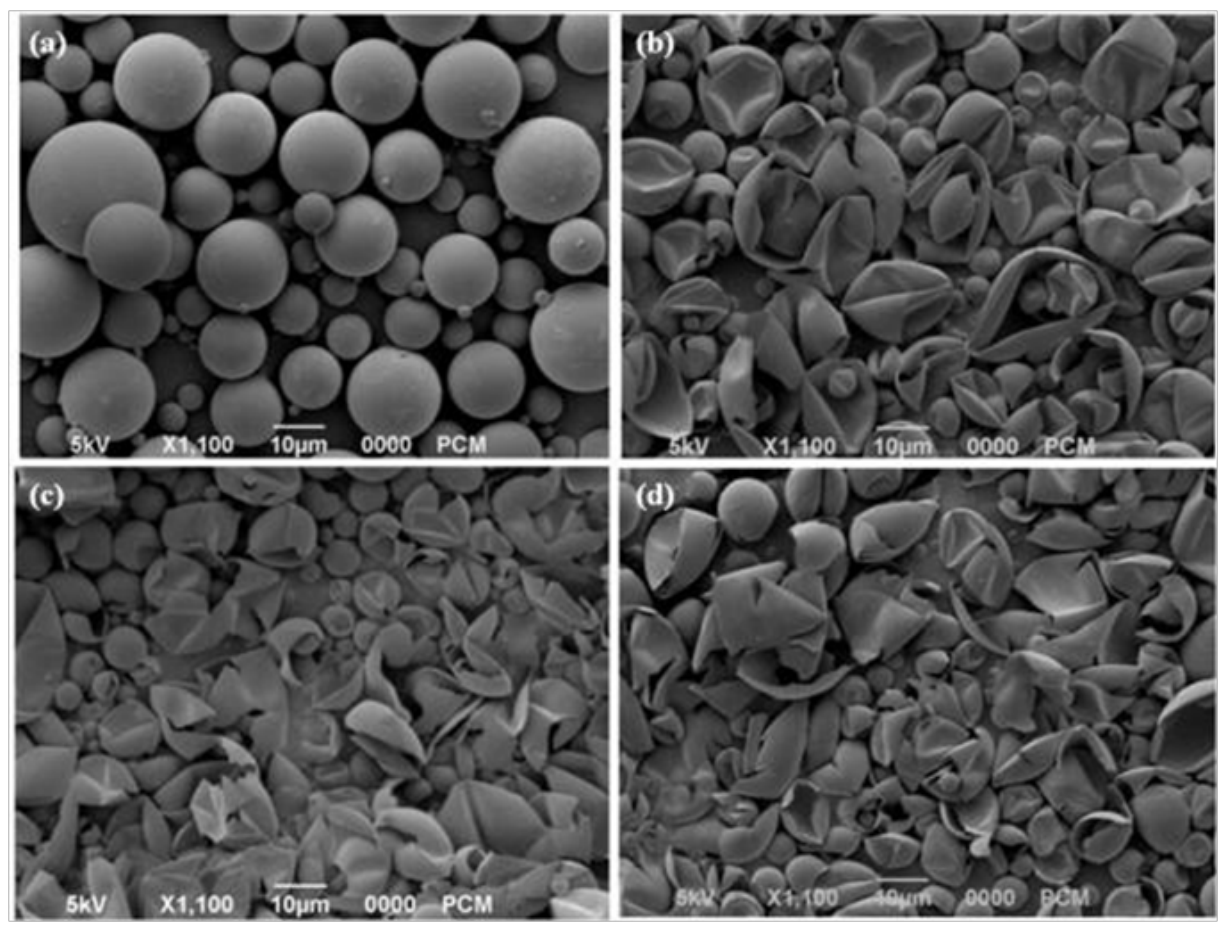

Axy Pagan-Vazquez, Dahtzen Chu, John Straube, et al. ERDC/CERL TR-15-10. Using Thermal Bridging Factors in Energy Models, http:/lacwc.sdp.sirsi.net/client/en US/search/asset/1044033

Approximately $25 \%$ of DoD's total energy use is consumed by buildings-over 577,000 buildings on more than 5300 sites. In 2006, DoD spent over $\$ 3.5$ billion for energy for fixed installations. The Energy Independence and Security Act (2007), and Energy Policy Act (2005) require the Army to dramatically reduce overall facility primary energy usage over the coming decades. The Army Energy Security Implementation Strategy (DA 2009) laid out the Department of the Army's strategy for large energy reductions. More recently, the Army published the "Army Vision for Net Zero," which states the ambitious goal of reaching Net Zero Energy at all fixed installations (ASA[IE\&E] 2012).

Achieving this goal will require the implementation of building envelope performance requirements not yet seen in the Federal government. The building envelope represents an area of much needed improvement in these facilities. Although guidance has already been published to encourage much more efficient building envelopes, it does not address the "thermal bridge," i.e., the part of an envelope in which heat transfer is greater than would 
be expected in a wall made up of common planar layers (e.g., gypsum wallboard, insulation, sheathing, and cladding).

To help the Army meet mandated energy reduction goals, this work developed a number of heat transmittance factors for use in including the heat loss of thermal bridging in the energy analysis of buildings. This work provides practical guidelines for the mitigation and reduction of thermal bridge problems in existing and new Army facilities. A wide range of building types was investigated from which nine common types were identified, and a number of important thermal bridge details were chosen for each. A list of details was compiled, from which 30 were chosen for detailed analysis based on their significance.

Convection loops can easily occur between the insulation and the structure in an interior retrofit if a gap is left.

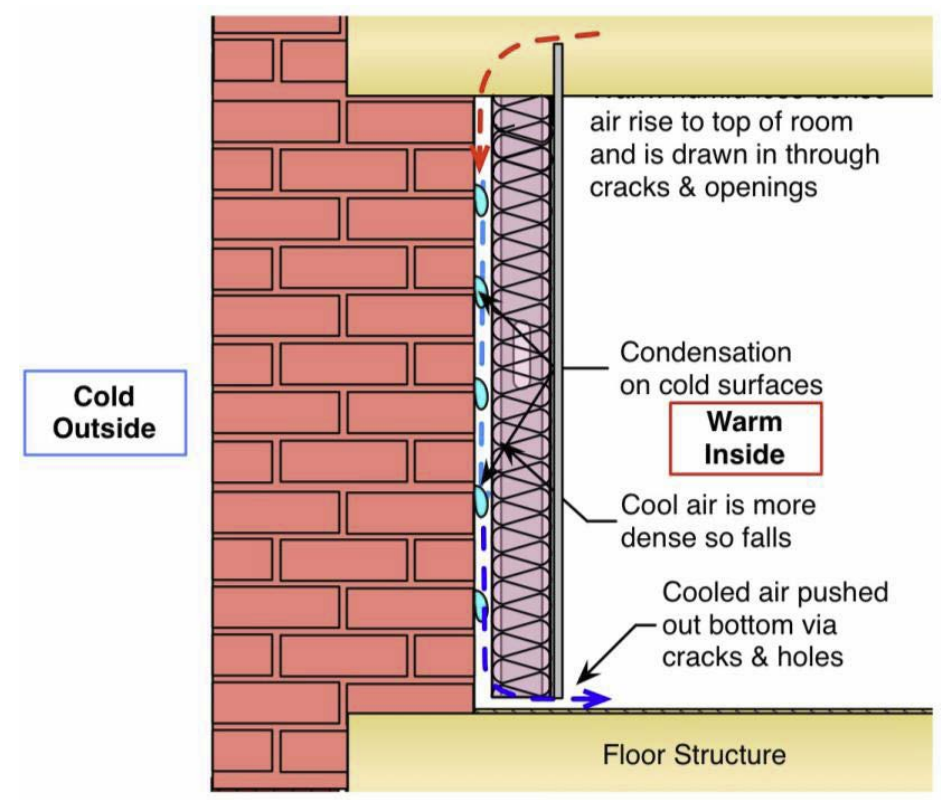

David M. Underwood, Alfred Woody, Michael Murphy, et al. ERDC/CERL TR-14-5. Exhaust Hood and Makeup Air Optimization. (Distribution D)

DoD has established challenging goals to increase energy efficiency and reduce GHG emissions of its installations in all five services. ESTCP was created to demonstrate and validate promising innovative environmental technologies and methodologies that address DoD's high priority environmental requirements.

This ESTCP demonstration project evaluated the energy savings potential of variable flow exhaust hoods using demand control ventilation (DCV) in dining facilities while maintaining or improving occupant comfort. Dining facilities at DoD installations, which typically serve many meals in short time periods, are excellent candidates for DCV type equipment to reduce energy use of the main kitchen hoods. DCV equipment automatically monitors cooking activity to increase the exhaust air flow only when needed by measuring exhaust air temperature, infrared temperature sensing of cooking surfaces and/or the presence of smoke/steam. This equipment greatly reduces exhaust air flow from the kitchen hoods when they operate at full air flow during kitchen operating hours.
Burger King kitchen hood (Ellsworth Air Force Base).

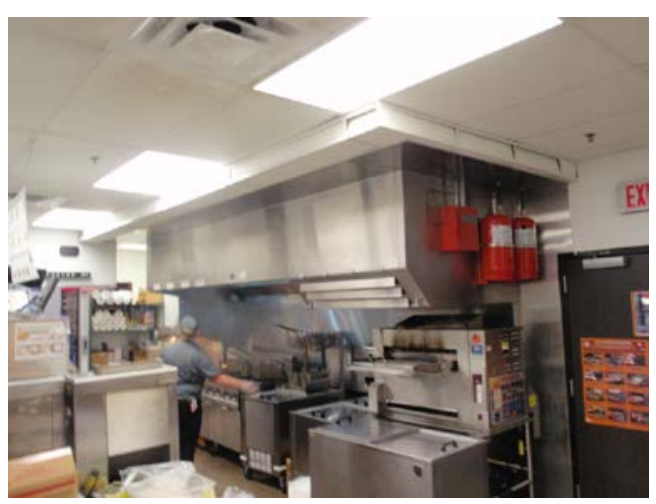


This project installed DCV systems on the main kitchen hoods at four different types of dining facilities in several climate zones. Measurements were taken before and after the installation of exhaust and makeup air unit fan motor electrical use, fan speed, makeup air unit supply temperatures and kitchen space temperatures. Energy savings were determined after taking measurements for several months. The annual cost savings were then calculated and the economic payback identified. Based on the measured values, the economics of installing DCV equipment on kitchen hoods in dining facilities throughout the United States are also presented.

James P. Miller. ESTCP Report. Kinetic Super-Resolution Long-Wave Infrared (LWIR) Thermography Diagnostic for Building Envelopes, https://www.serdp-estcp.org/content/download/34401/332473/file/EW-201241-FR.pdf

James P. Miller and Navi Singh. ERDC/CERL TR-15-17. Kinetic Super-Resolution Long-Wave Infrared (LWIR) Thermography Diagnostic for Building Envelopes: Scott AFB, IL, http:/lacwc.sdp.sirsi.net/client/en US/search/asset/1045552

James P. Miller and Navi Singh. ERDC/CERL TR-15-18. Kinetic Super-Resolution Long-Wave Infrared (LWIR) Thermography Diagnostic for Building Envelopes: Camp Lejeune, NC, http:/lacwc.sdp.sirsi.net/client/en US/search/asset/1045553

Each year, DoD buildings waste millions of dollars' in energy lost through leaks in building envelopes. Identifying the source of this wasted energy has historically been time consuming and prohibitively expensive for large-scale energy analysis. This work used an independently developed drive-by thermal imaging solution that can enable DoD to achieve cost-effective energy efficiency at much greater scale than other commercially available techniques of measuring energy loss due to envelope inefficiencies from the built environment. A multi-sensor hardware device is attached to the roof of a customized vehicle to rapidly scan hundreds of buildings in a short period of time.

At Scott Air Force Base, the unit identified over 3,000 distinct building feature components (doors, windows, soffits, etc.) on buildings across the base. At U.S. Marine Corps Base Camp Lejeune, the unit identified over 2500 distinct building feature components identified across various buildings throughout the base. These features were categorized by type and surface temperature to provide an in-depth analysis of each building's envelope energy profile. This report includes an in-depth analysis of 30 buildings at each installation, recommends specific

Specially equipped scanning vehicle.

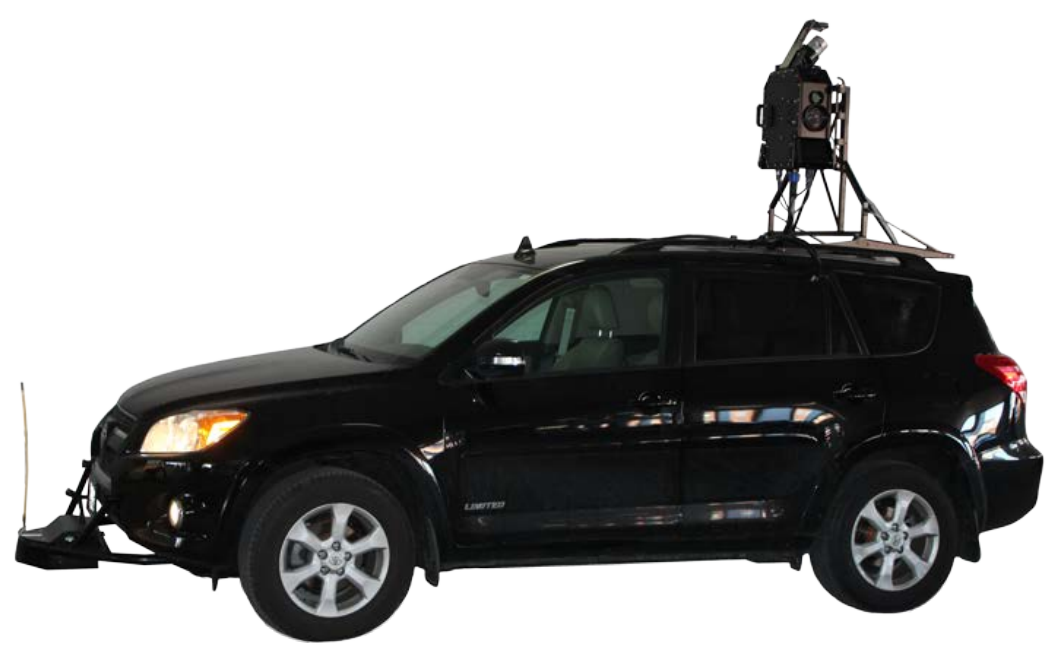
energy conservation measures (ECMs), and quantifies significant potential return on investment.

At U.S. Marine Corps Base Camp Lejeune, the unit identified over 2500 distinct building feature components identified across various buildings throughout the base. These features were categorized by type and surface temperature to provide an in-depth analysis of each building's envelope energy profile. This report includes an in-depth analysis of 30 buildings at each installation, recommends specific ECMs, and quantifies significant potential return on investment. 
L. D. Stephenson, Andrew Heffron, Brenda B. Mehnert, et al. ERDC/CERL TR-15-8. Prediction of Long Term Degradation of Insulating Materials, http://acwc.sdp.sirsi.net/client/en_US/search/asset/1043709 Advanced insulation materials provide resistance to heat flow. Properly insulating shelters can reduce heating and cooling costs, as well as improve comfort. However, the long-term performance of insulation materials is relatively unknown. This research investigated the long-term performance of five commercially available insulation materials including non-woven insulation liner, aerogel blankets, closed cell spray polyurethane foam (ccSPF), extruded polystyrene (XPS), and fiberglass batt. Accelerated aging simulation experiments were conducted in an environmental chamber. All materials were subjected to 5 weeks in the chamber and exposed to various temperature and humidity conditions. Thermal conductivity using a heat flow meter apparatus and corresponding R-values of each material were calculated. The results indicate that moisture absorption was a major contributor to changes in the thermal properties of the materials. Additional degradation in R-values in ccSPF was caused by loss of blowing agent over time. The results of this research are expected to help formulate an accelerated aging methodology that allows reliable prediction of long-term advanced insulation materials performance.

Utilis TM60 shelter with nonwoven composite insulation (Thinsulate ${ }^{T M}$ ) liner (Camel Manufacturing, Pioneer, TN).

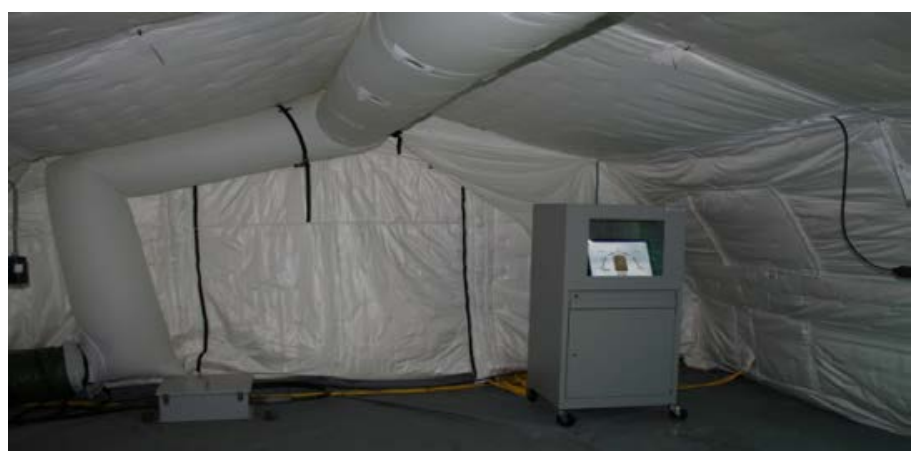

James P. Miller, David M. Underwood, Laura E. Curvey, et al. ERDC/CERL TR-15-7. Level / Energy and Water Survey, ERDC-CERL, Champaign, IL, http://acwc.sdp.sirsi.net/client/en US/search/asset/1043646 This energy and water survey at ERDC-CERL identified energy and water inefficiencies and waste, and proposed energy and water-related projects that would enable the installation to better meet mandated energy and water reduction requirements. The survey included a Level I energy and water optimization assessment study, which reviewed the Main Complex and other buildings within the secured perimeter. The leased AT\&T facility was not included in the study since ERDC-CERL intends to vacate the AT\&T facility within the next 2 years. Also, the EFOB-L facilities on the north edge of the ERDC-CERL property were not included in the study since these facilities currently receive very minimal electrical support from the Main Complex.

The study identified nine economically viable ECMs that, if implemented, would substantially reduce ERDC-CERL's annual energy consumption. These ECMs are presented in three groups according to the size of the required investment for each ECM. The study also identified four economically viable ("Iow-cost") water conservation measures (WCMs) that, if implemented, would reduce ERDC-CERL's annual water use by up to $207 \mathrm{kgal} / \mathrm{yr}$.

Sean W. Morefield and Jorge L. Alvarado. ERDC/CERL MP-15-1. Field Validation of Microencapsulated Phase-Change Material Slurries as Heat-Transfer Fluids, https:/lwww.serdpestcp.org/content/download/35686/342045/file/EW-201154-Technical\%20Memo.pdf

Thermal management of facilities and processes on military installations requires the continual pumping of large volumes of a heat-transfer fluid (HTF). Laboratory studies have shown that HTFs infused with microencapsulated phase-change materials (MPCMs) have a higher 
heat-carrying capacity than conventional HTFs; the use of MPCMs could reduce the required fluid-flow rate and, thus, system power costs. This study demonstrated the performance of MPCM slurries under continuous pumping conditions in full-scale applications at two U.S. military installations. An instrumented test loop was temporarily integrated with ground-source heat-exchange systems at Fort Hood, TX, and Fort Dodge, IA, to compare the thermal performance and pumping-power requirements of conventional HTFs and MPCM slurries.

Premature capsule breakage during early tests was addressed by thickening capsule walls and replacing the centrifugal circulation pump with a progressive cavity pump to reduce mechanical shear stresses. MPCM heat-carrying capability varied with mass ratio between capsule wall and phase-change material. The heat-transfer coefficient of performance for MPCMs was seen to improve at least $10 \%$ over conventional HTFs, with system power-consumption reductions of at least 3\%. An economic assessment indicates that implementation of MPCMs as a drop-in application could provide a 1.77 return on investment ratio. However, results suggest that the technology is not mature enough to recommend for widespread drop-in implementation at this time.

Victor F. Medina. Richard J. Scholze, Scott A. Waisner, et al. ERDC SR-15-2, Energy and Resource Recovery from Wastewater Treatment: State of the Art and Potential Application for the Army and the DoD, http:/lacwc.sdp.sirsi.net/client/en US/search/asset/1043946 This study assessed energy and resource recovery from wastewater treatment and shortand long-term opportunities and impacts for the Army and DoD in general. The organic material in wastewater contains inherent energy. The challenge is concentrating and recovering this energy. Of the several methods available, anaerobic digestion (either of the sludge, or directly applied to the wastewater using an Upflow Anaerobic Sludge Blanket or a similar reactor) is the most advanced and can be readily applied to existing military installations or to contingency operations. Recovery of chemical products is another option for wastewater treatment. The most commonly recovered products are nutrients, in the form of nitrogen $(N)$ and phosphorus $(P)$. The simplest way is to recycle the collected and digested biosolids (sludges), either for direct soil application or by incorporation into compost. Resource recovery from wastewater may eventually include biopolymers that could make bioplastics or valuable nanometals that are increasingly found in consumer products. Many of the energy recovery technologies and most of the resource recovery approaches (beyond simple biosolids recovery) require large-scale operations to be economically viable at this time. Wastewater treatment facilities that serve Army and other DoD installations tend to be relatively small, limiting the application of many approaches that might be practicable in the civilian sector. The report recommends that ERDC should focus research on technologies that could be economically applied to smaller treatment plants on the order of 3 to $10 \mathrm{mgd}$. 
Brendan A. West, Charles C. Ryerson, and Keran J. Claffey. 2015. ERDC/CRREL TR-15-18.

NHARNG Wind Resource Assessment: Center Strafford Training Center,

http:/lacwc.sdp.sirsi.net/client/search/asset/1047667

The New Hampshire Army National Guard (NHARNG) training facility in Center Strafford, $\mathrm{NH}$, wishes to supply at least $25 \%$ of its energy needs with renewables by 2025 to meet Army and DoD energy goals. They commissioned the Cold Regions Research and Engineering Laboratory (CRREL) to determine the feasibility of wind energy meeting this requirement. Aiming to meet industry standards for assessment, CRREL acquired meteorological wind data from J une 2012 through May 2014; performed data quality control; estimated turbulence, wind shear, and speed distributions; and estimated energy production and payback periods for five $100 \mathrm{~kW}$ wind turbines. The best performing turbine assessed at a hub height of $37 \mathrm{~m}$ could provide $52 \%$ of the site's annual electric power needs with a payback of approximately 18 to 19.6 years. However, extrapolated long-term wind speeds suggest the best performing turbine assessed could provide $71 \%$ of the site's annual electric power needs; and the payback would drop to approximately 14 years. CRREL also assessed the feasibility of a comparable solar energy system at Center Strafford, and the payback for a fixed-array system is $14-16$ years and 11 years for a twoaxis array system.

Left and top right: glaze ice on anemometers and wind vanes. Bottom right: hoarfrost that formed under clear night skies.

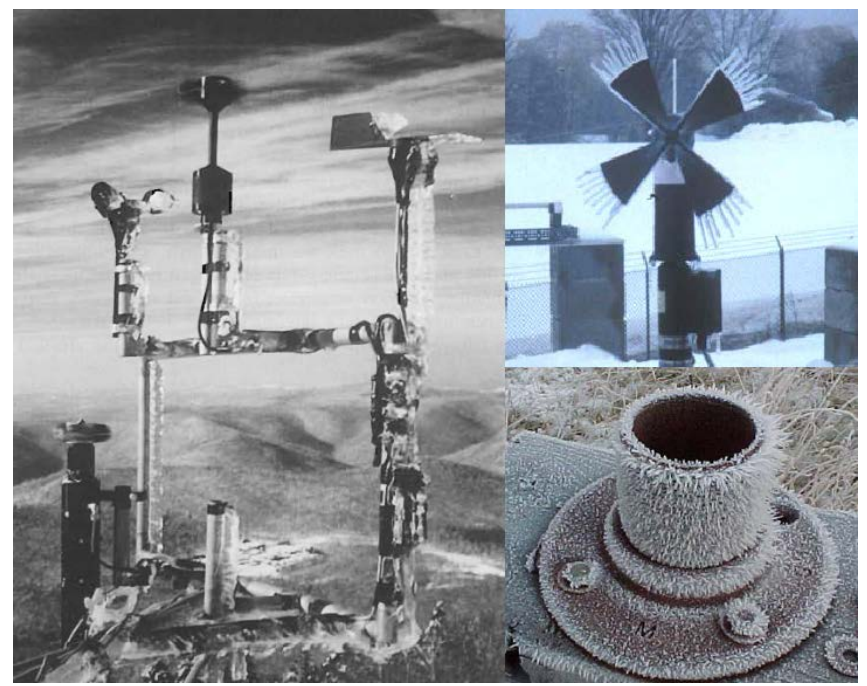




\section{Sustainable Water \& Waste Resources}

In recent years, military installations have been impacted by conditions of increasing demand and decreasing supply of high quality fresh water. Urban growth adjacent to installations has combined with prolonged regional droughts to place key military missions at risk due to limited availability of this vital resource. Regional competition for water threatens continued availability of adequate water both on post and in adjacent urban areas.

This focus area addresses access to, and the sustainable use of, water resources. Activities include understanding water resources status, quantities and qualities; conservation approaches and technologies; water reuse technologies and approaches; and other capabilities to improve and enhance the availability and quality of water as a sustainable resource.

Anne Koster. PWTB 200-1-141. Implementing Stormwater and Erosion Control Technologies in Urban-Type Military Range Designs, http://www.wbdg.org/ccb/ARMYCOE/PWTB/pwtb 200 1 141.pdf PWTB 200-1-141

Current regulations require new federal facilities over $5,000 \mathrm{sq} f t$ to maintain or restore the predevelopment hydrology state of the property with regard to the temperature, rate, volume, and duration of flow. In range design, Low Impact Development (LID) technologies are appropriate to maintain natural hydrologic function during and after range construction and throughout the site's use. Army range designs must also now be adapted to meet sustainability goals of several drivers: Army Net Zero, the DoD Strategic Sustainability Performance Plan (SSPP), current sustainability-oriented Army regulations, and federal legislation. Compliance issues may arise if management strategies are not in place to respond. One area of maximum impact is stormwater management. Site hydrology has become important due to the concurrence of increasing water requirements by installations and water shortages in certain geographic locations.

This Public Works Technical Bulletin (PWTB) provides guidance for successful implementation of sustainable in-field best management practices (BMPs) and LID design technologies within urban training areas (UTAs) on Army installations. This guidance helps U.S. Army installations take a proactive stance to use efficient, sustainable designs that will save money in both long-term design and lifespan maintenance. The designs suggested in this PWTB promote infrastructure stability and ensure that buildings, roads, and ditches will continue to support training throughout the life span of each UTA.

Herbicide-treated gravel pad (unaltered view on top). The altered bottom image shows bare soil in purple, with vegetation death shown in red.
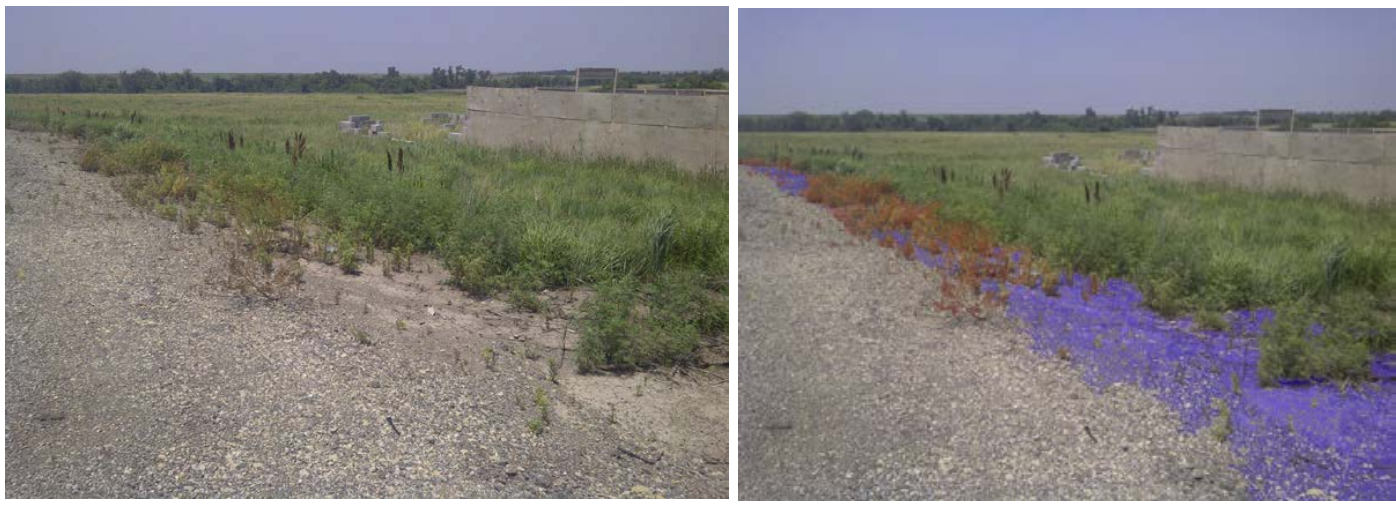
Donald K. Hicks. PWTB 200-1-144, Toxics Management,

http://www.wbdg.org/ccb/ARMYCOE/PWTB/pwtb_200_1_144.pdf

This PWTB provides installations with guidance on how to address specific toxic and hazardous materials associated with buildings and some structures that are owned, leased, or otherwise controlled by the Department of the Army. This bulletin communicates on two levels. First, it addresses the garrison leadership and the senior managers of the Directorate of Public Works (DPW) on organizational topics of their concern (organizing a toxics management team). It then addresses technicians, supervisors, and persons doing the actual daily work on how to control four toxics that present a unique challenge to the installation Toxics Management Team: (1) Asbestos, (2) Lead, (3) Polychlorinated Biphenyl (PCBs), and (4) Radon.

Veera M. Boddu. PWTB 200-1-145. Recycle of Solvent Cleaners for Tactical and Transportation Vehicles, http://www.wbdg.org/ccb/ARMYCOE/PWTB/pwtb 2001 145.pdf

U.S. Army vehicle maintenance facilities attempt to select environmentally friendly surface cleaners that are free of Hazardous Air Pollutants (HAPs), that contain the minimum possible amounts of Volatile Organic Compounds (VOCs), and that eliminate GHG emissions. They also consider the costs associated with the cleaners and the amount of waste generated from the cleaning process. This PWTB identifies and provides recommendations on how to extend the life of the cleaning tanks by filtering dirt, oils, and tar from the cleaning fluid and fortifying it with the addition of depleted active ingredients or fresh concentrated solvent, thus reducing both purchase costs and costs associated with waste disposal.

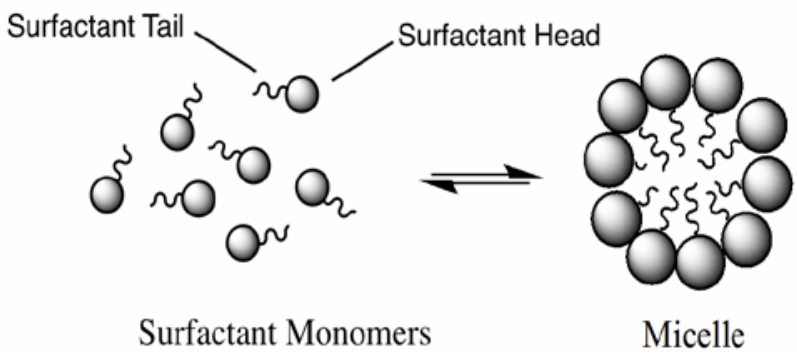

Schematic of surfactant monomers forming a surfactant micelle

John L. Vavrin and lan McNamara. ERDC/CERL TR-14-24. Base-Wide Biodigester for Basecamps in an Operational Environment, http:/lacwc.sdp.sirsi.net/client/en US/search/asset/1036663

Waste disposal in a contingency environment places a burden on the logistics, fuel supply, and security at contingency bases (CBs). Unlike their counterparts at fixed installations in the United States, personnel who live and work at basecamps are required to handle, treat, and dispose of all waste streams. These waste-handling efforts divert valuable resources from the primary mission(s) of the basecamp personnel and burden the entire logistical chain. Base management must consider the complex interdependency between power, fuel, and solid waste management, all of which must be carefully managed under difficult and dangerous conditions.

As part of the effort to provide effective waste management techniques in contingency environments, ERDC-CERL investigated the use of anaerobic digesters for food waste disposal. Anaerobic digesters can reduce the amount of solid waste requiring disposal, produce a net amount of electricity that can help power the base, and produce thermal energy for heating. This study determined that it was feasible and cost effective to install anaerobic digesters at large (10,000 personal) enduring CBs. 


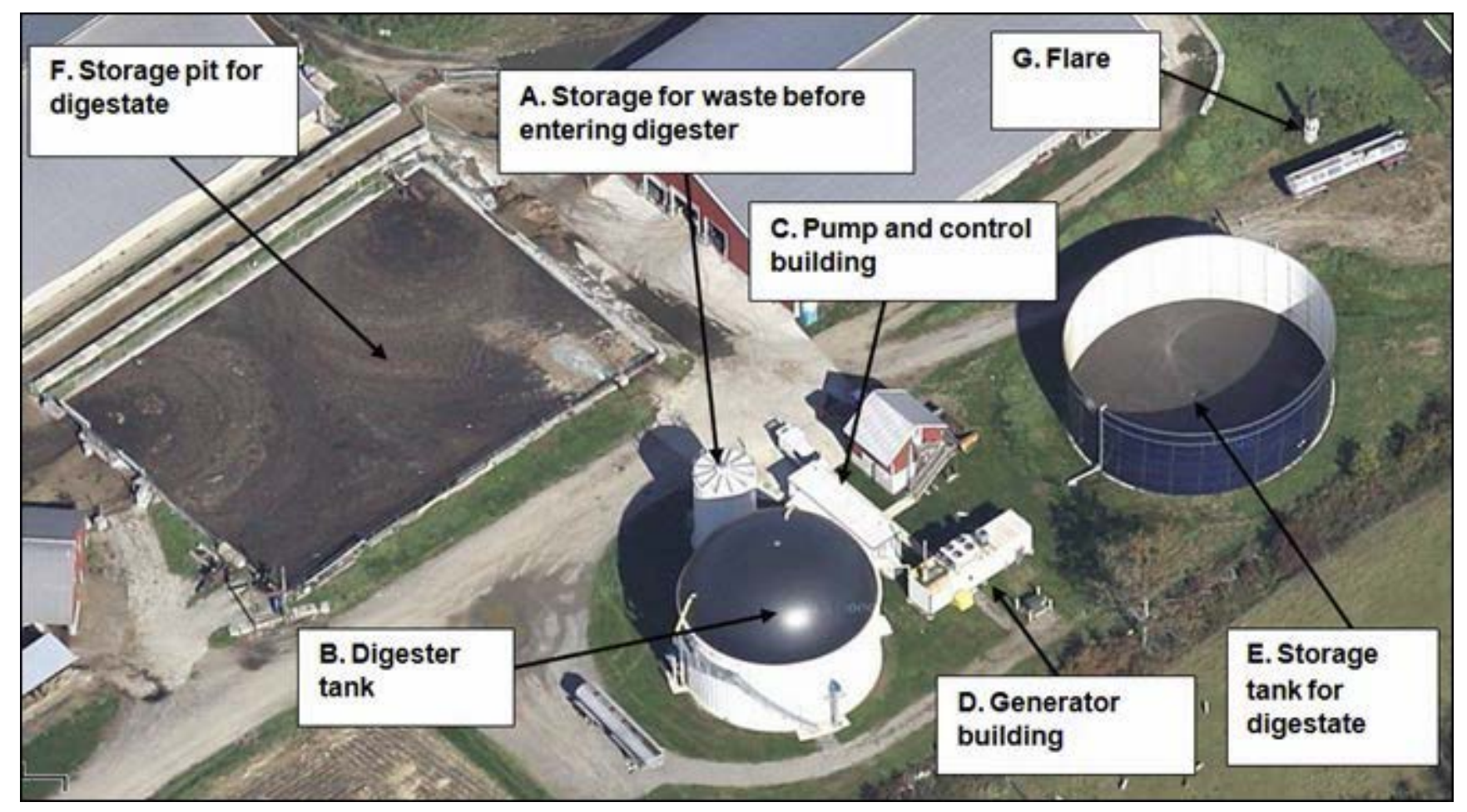

Arial view of the food waste and cow manure digester

Victor F. Medina, Richard J. Scholze, Scott A. Waisner, et al. ERDC SR-15-2. Energy and Resource Recovery from Wastewater Treatment: State of the Art and Potential Application for the Army and the DoD, http:/lacwc.sdp.sirsi.net/client/en US/search/asset/1043946

This report summarizes a study to assess energy and resource recovery from wastewater treatment and assess short- and long-term opportunities and impacts for the Army and DoD in general. The organic material in wastewater contains inherent energy. The challenge is concentrating and recovering this energy. Several methods are available; of these, anaerobic digestion (either of the sludge, or directly applied to the wastewater using an Upflow Anaerobic Sludge Blanket or a similar reactor) is the most advanced and can be readily applied to existing military installations or to contingency operations.

Recovery of chemical products is another option for wastewater treatment. The most commonly recovered products are nutrients, in the form of nitrogen $(\mathrm{N})$ and phosphorus $(\mathrm{P})$. The simplest way is to recycle the collected and digested biosolids (sludges), either for direct soil application or by incorporation into compost. Resource recovery from wastewater may eventually include biopolymers that could make bioplastics or valuable nanometals that are increasingly found in consumer products.

Many of the energy recovery technologies and most of the resource recovery approaches (beyond simple biosolids recovery) require large-scale operations to be economically viable at this time. Wastewater treatment facilities that serve Army and other DoD installations tend to be relatively small, limiting the application of many approaches that might be practicable in the civilian sector. ERDC should focus research on technologies that could be economically applied to smaller treatment plants on the order of 3 to $10 \mathrm{mgd}$. 
Victor F. Medina, Michelle Wynter, Stephen Cosper, et al. ERDC TR-14-2. Assessment of Composting for Organic Solid Waste at Fort Polk, Louisiana, http:/lacwc.sdp.sirsi.net/client/en_US/search/asset/1034162

A study was conducted to evaluate composting as a means of increasing waste diversion at Fort Polk, LA. Wastes were evaluated from a range of activities, and the authors found that a number of materials currently landfilled are suitable for composting, including: vegetation, food wastes, pulverized paper (which is not suitable for recycling), consumer-contaminated paper (not suitable for recycling), damaged wood pallets, and sludge from the wastewater treatment plants. Waste records from Fort Polk suggest a composting operation producing at least 2200 tons per year (from a food waste/vegetation strategy) is feasible. This would represent considerable solid waste diversion, consistent with meeting Net Zero Waste Goals. Between the Integrated Training Area Management (ITAM), the Directorate for Family, Morale, Welfare, and Recreation (golf course, athletic and drill fields), and smaller groups, there are enough users to consume all the compost that could be generated from an on-site operation. A suitable area for onsite composting is available. There are also other alternatives to on-site composting, including current

Schematic of a static pile composting operation

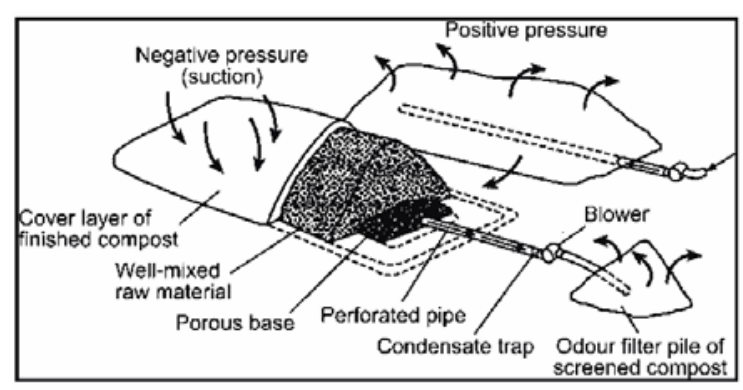
management, which is outlined in this report; other means of waste diversion (including direct soil application of certain waste materials and anaerobic digestion of food wastes); and the possibility of developing partnerships with composting facilities offsite. Although this project is focused on Fort Polk, the assessment could be - in a broad sense - applicable to other Army installations. In addition, the issues found at the Joint Training and Readiness Center might have applicability to contingency environments and deployed operations.

\section{Terry D. Melendy, Robert Haehnel, and Kent Colby. 2014. ERDC/CRREL TR-14-17. Waste Water Handling Proof of Concepts at McMurdo Station, Antarctica, http:/lacwc.sdp.sirsi.net/client/search/asset/1036480}

Raytheon Polar Services Company implemented two proof-of-concept waste handling methods for testing during the austral summers spanning 2010 to 2013 at Pegasus Airfield, McMurdo, Antarctica. These methods included a portable waste transfer tank and a waste incineration method. Testing and modification of these methods took place from 2010 to 2013 to determine the feasibility of long-term use of each method. Data for the actual

Incinerator and wastewater set up at Pegasus Runway, 2011-12.

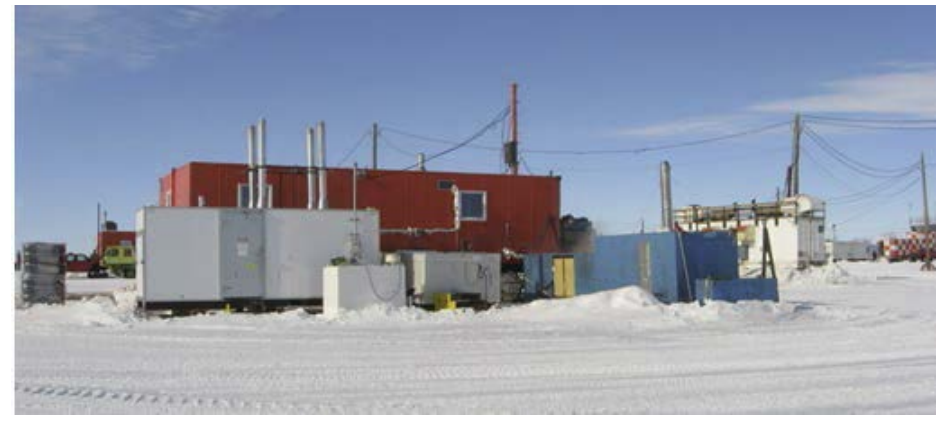

waste water production at the runway was limited before the start of these projects and was estimated to determine proper sizing of the two methods used. During proof-of-concept testing of these methods, a more accurate determination of the waste water production was obtained as well. This is invaluable data for developing a long-term solution to handle the wastewater produced at the airfield. Both of these methods proved to be viable options dependent on the amount and type of logistical support available. 


\section{Sustainable Facilities and Infrastructure}

The purpose of this focus area is to help the U.S. Army Corps of Engineers (USACE), the Army and DoD work toward achieving net-zero and sustainable planning, design and development goals. The focus area team leaders are part of the Sustainable Design and Development Directory of Expertise (SDD DX) that the Corps established to provide support in developing criteria, research and development, design and construction support services, and training and advisory assistance. In this technology area, CASI also provides support and collaboration with the U.S. Green Building Council (USGBC) and other organizations involved in sustainable design and development (SDD).

\section{Stephen D. Cosper. PWTB 200-1-143. Update of Opportunities for Reducing Construction and Demolition Waste from Residential Communities Initiative (RCI) Programs, http://www.wbdg.org/ccb/ARMYCOE/PWTB/pwtb 2001 143.pdf}

Disposal of construction and demolition (C\&D) debris at Army installations has become problematic in both economic and environmental terms. Installations with Facility Reduction Program requirements, active Military Construction (MILCON) programs, and $\mathrm{RCl}$ projects are facing a significant $C \& D$ debris burden. Army-wide, $C \& D$ debris comprises just over half of total waste generation; this figure can be much higher at installations with very active construction programs.

Landfilling C\&D debris also has environmental consequences. The U.S. Environmental Protection Agency (USEPA) has identified C\&D debris as a contributor to GHG emissions. This is just one of a number of concerns such as: the life-cycle environmental effects of extracting materials from the earth, the depletion of natural resources, the burden to landfill space, and the manufacture, transport, and disposal of virgin materials in lieu of reusing or recycling existing materials. As an example of the positive environmental impact, on average $75 \%$ of the dimension lumber can be recovered from a wood-framed building (Falk 2002). This PWTB provides updated information for the recovery, reuse, and recycling of building materials that are typically disposed of as demolition waste.

Concrete recycling with on-site crusher.

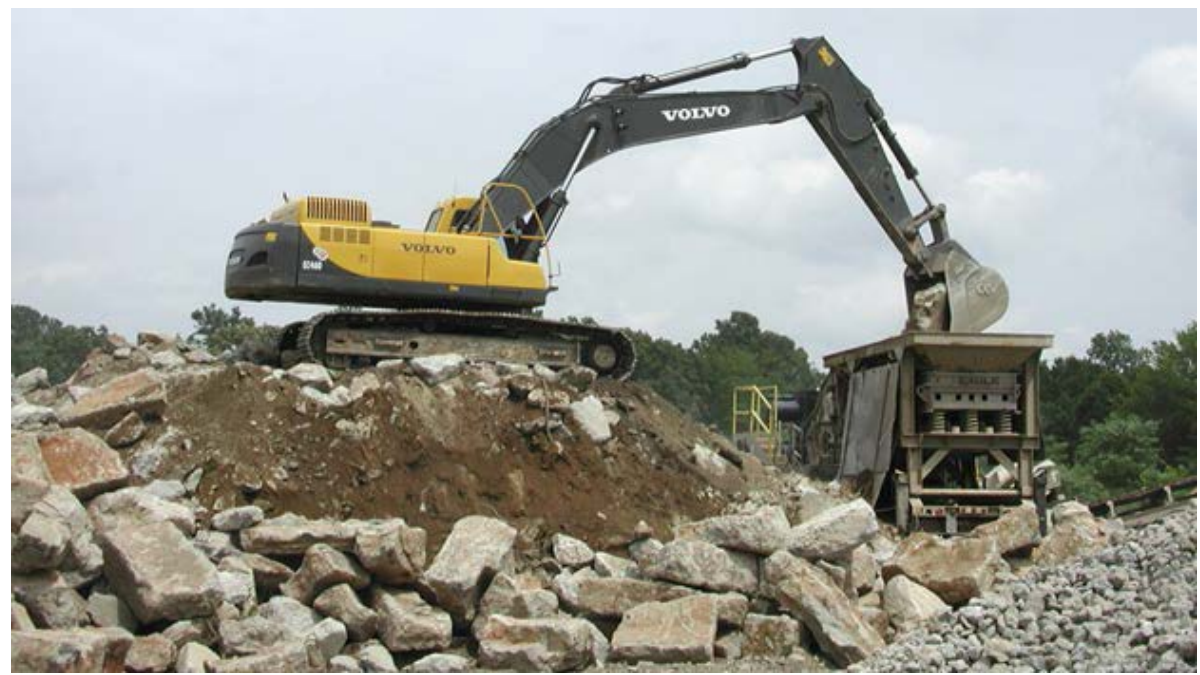


Thomas R. Napier. DRAFT ERDC/CERL SR. Application of Updated Construction and Demolition Waste Reduction Policy for Army Projects.

Waste reduction is a fundamental component of sustainability. The U.S. Green Building Council's (USGBC) Leadership in Energy and Environmental Design (LEED) includes credits for using existing building elements, incorporating recovered and recycled-content materials, and re-covering materials for reuse and recycling from demolition, new construction, and renovation and repurposing projects.

In its efforts to improve the sustainability of Army facilities, the Army has directed that waste generated through its various $C \& D$ programs be reduced. The first Army policy incorporating SDD principles into installation planning and infrastructure projects, including C\&D waste reduction, was issued in 2000, and the Assistant Secretary of the Army for Installations Management, Energy, and Environment (OACSIM-IE\&E) issued the SDD Policy Update in December 2013.

However, ERDC-CERLS's experience shows that success in deconstruction projects depends greatly on project execution. That is, the "how" deconstruction projects are executed is equally critical, if not more so, as the "if" a de-construction approach should be applied. This document provides guidance for the implementation of updated Army guidance for C\&D waste management and reporting process for Army construction, demolition, and renovation/repurposing projects, which may be administered through the U.S. Army Corps of Engineers (USACE) or locally through installations' DPWs.

\section{Thomas R. Napier. Draft ERDC/CERL SR, Removing Hazardous Materials from Buildings: $A$ Training Curriculum.}

There has been little or no direct training available within the Army for installation personnel to appropriately identify, handle, and dispose of hazardous materials in Army buildings. As the Army's recent new construction programs wind down, attention must be paid to operation, repair, and renovation of existing facilities-facilities where hazardous materials are more likely to be encountered. An ad hoc, reactive approach to dealing with hazardous materials will adversely impact repair, renovation, and operation budgets and schedules. Development of a training regimen has been previously deferred, but is now being addressed. At the direction of the Office of the Assistant Chief of Staff for Installation Management (OACSIM) Facility Policy Division (DAIM-ODF) completed a PWTB titled "Toxics Management" that was published through Headquarters, U.S. Army Corps of Engineers. That publication provides guidance to address specific toxic and hazardous materials associated with buildings that are owned, leased, or otherwise controlled by the Department of the Army. In addition, the training curriculum captured in this report now presents a workshop-style training curriculum that will enable installation operations and management personnel to identify, handle, and dispose of hazardous building materials in a safe, thorough, efficient, and economical manner.

\section{Ellen Hartman. DRAFT ERDC/CERL SR. Finding Space: A Field Guide for Incorporating Low Impact Developments into Military Historic Districts.}

DoD has been tasked by the Energy Independence and Security Act of 2007 and Executive Order 13693, "Planning for Federal Sustainability in the Next Decade," to conserve and protect water resources through increased efficiency, reuse, and management. As a result, sustainable stormwater management strategies are being incorporated throughout the military's built environment to manage stormwater in ways that work with natural hydrologic systems. Collectively, those strategies are called LID. Incorporating LID technologies, or LID BMPs, in designated historic districts requires advanced planning, site analysis, compliance with federal regulations, and coordination between diverse stakeholders. This field guide explains the complex interaction between regulatory requirements and the physical environment to assist cultural resource managers in coordinating with all stakeholders to successfully plan and implement sustainable stormwater management systems. 
Anne Koster. PWTB 200-1-150. Multinational Analysis of Military Vehicle Impacts and Regulatory Pressures on Training Land Management, http://www.wbdg.org/ccb/ARMYCOE/PWTB/pwtb_200_1_150.pdf

To gain strategic insight into effective and efficient land management practices, this PWTB documents how certain U.S.-allied nations have dealt with challenges related to intensified human development, encroachment, soil conservation, climate change, and ecosystem management on their military training lands. The opportunities identified and lessons learned are presented to enable the U.S. Army to save money, optimize co-land utilization, and preserve training land resources over the long term. Innovative technologies may have been developed in other countries to deal with more stringent regulations, and this project reviews applicable foreign solutions, identifies solutions for use within the U.S. Army, and projects potential up-and-coming regulatory pressures (e.g., proposed new Threatened and Endangered Species [TES] listings). The knowledge gained from this effort may bolster stewardship, enhance land rehabilitation, and promote military training sustainment.

Anne Koster. PWTB 200-1-148. Creative Strategies and Opportunities for Managing Cultural Resources on Army Training Lands, http://www.wbdg.org/ccb/ARMYCOE/PWTB/pwtb 200 1 148.pdf

DoD installations have a responsibility to maintain stewardship of the cultural resources on lands they own or manage. Of all the military service branches, the U.S. Army holds the largest inventory in major categories of land and cultural/historic resources. These historic and cultural resources are assets to the nation's heritage, but can also be considered assets to the training mission of Army installations within the continental United States (CONUS). Because of the high national and military asset value of cultural resources to the Army, installation management strategies for cultural resources are important to the management approach taken within installation cantonment areas as well as on training ranges. This PWTB identifies creative and innovative technologies and BMPs for cultural resources and site management on Army training lands. To facilitate sharing of BMPs, this publication details known examples from actual projects. In addition to the benefit of information sharing, cost savings and increased land availability also will result from efficient integration of cultural resource management with site and training area land management BMPs described in this PWTB.

At Defence Training Estate (DTE) Otterburn and DTE Salisbury Plain (UK), grazing is a land management practice for vegetative cover maintenance.

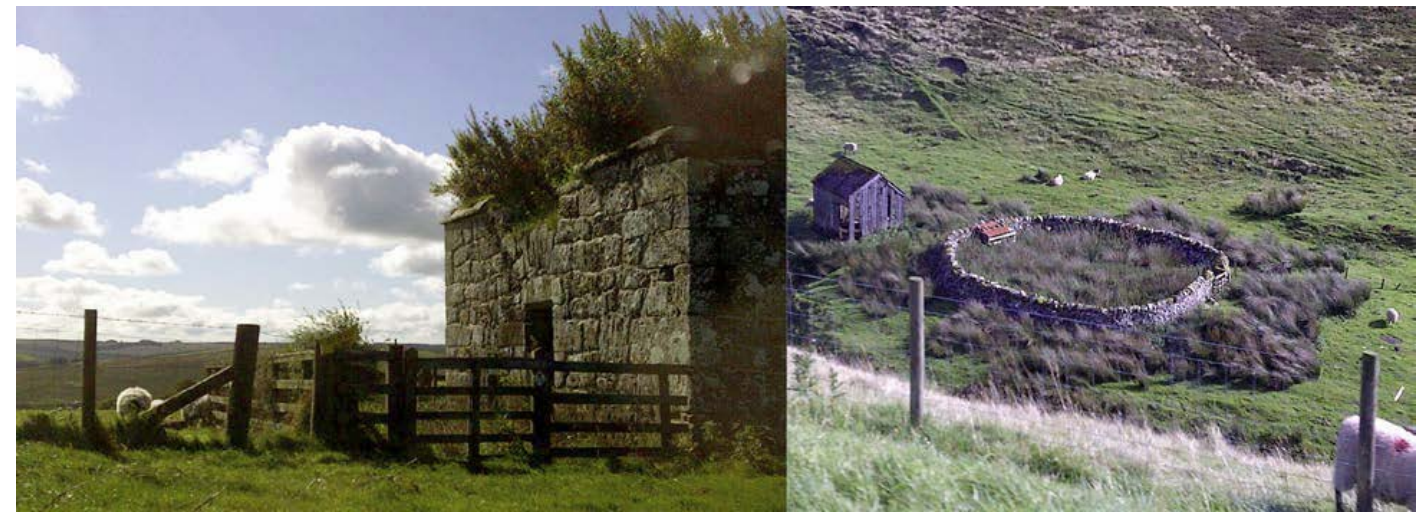

Richard G. Lampo. ERDC/CERL TR-15-29. [F09-AR02] Demonstration and Validation of Materials for Corrosion-Resistant Fencing and Guard Railings in Aggressive Climates, http:/lacwc.sdp.sirsi.net/client/en U.S./search/asset/1046352

Standard galvanized steel chain-link fencing, including products coated with polyvinyl chloride (PVC), can severely corrode in as little as 5 years in coastal locations where the atmosphere is warm, humid, and infused with chlorides. This problem affects fencing needed to 
secure military equipment, supplies, and buildings. Painted and galvanized-steel safety railings also can severely corrode in those environments, creating personal-safety hazards. This study assessed several alternative corrosion-resistant materials for fencing and railings using atmospheric exposure coupons and full-scale installations. The research design compares the performance of the alternative and conventional materials to identify those that may reduce the Army's corrosion prevention and control costs, including fuse-bonded PVC, galvanized steel, stainless steel, aluminized steel, a proprietary material called Galfan ${ }^{\circledR}$, aluminum alloys, and fiber-reinforced polymer (FRP) composites. The test exposure sites were Kahuku, HI; Duck, NC; and Treat Island, ME.

\section{Railing and wire coupons on exposure rack}

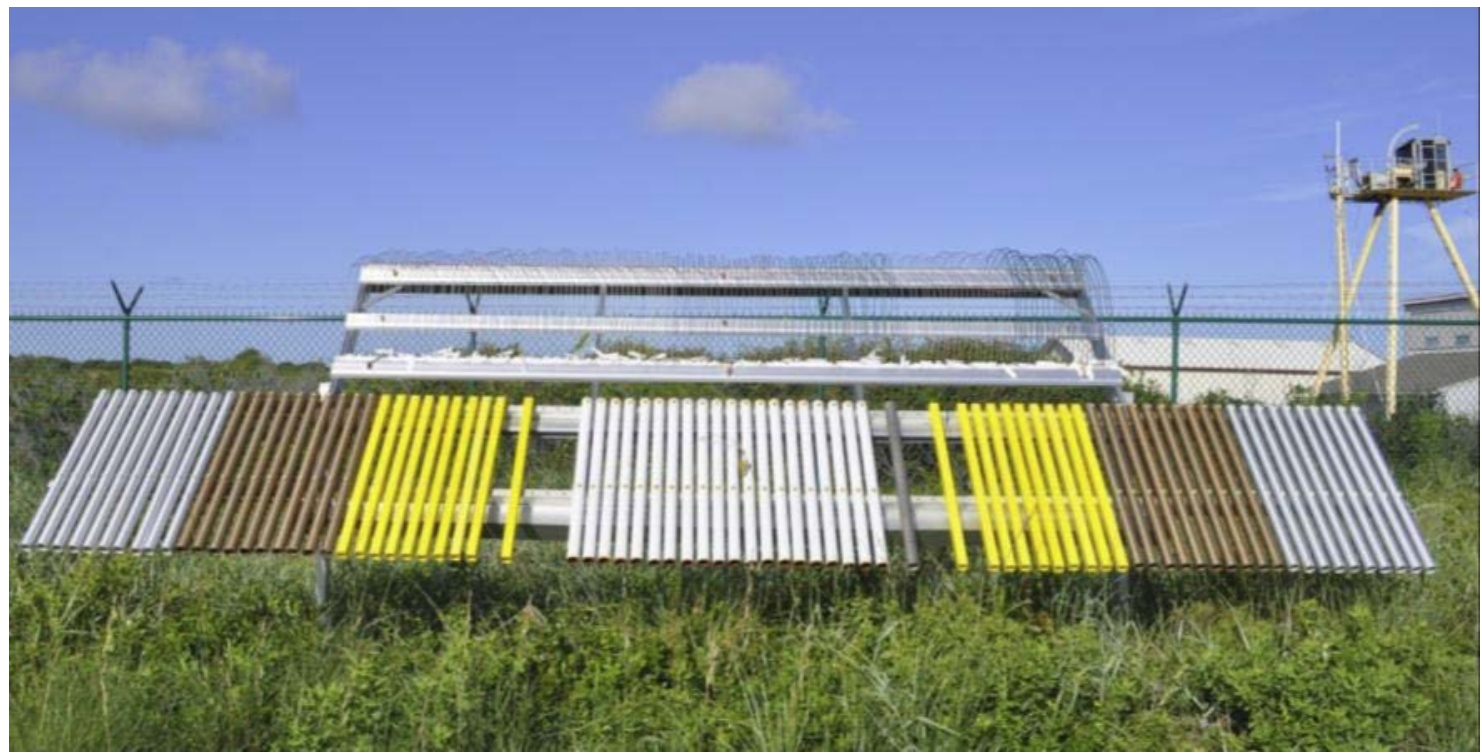

David M. Bailey. ERDC/CERL TR-14-3. [F08-AR14] Demonstration of Photovoltaic-Powered Cathodic Protection System with Remote Monitoring Capability,

http:/lacwc.sdp.sirsi.net/client/en U.S./search/asset/1033680

This project demonstrated an application of photovoltaic (PV) technology to power cathodic protection (CP) systems for water tanks at Pohakuloa Training Area (PTA), HI. An impressed-current CP system was installed on each of three water tanks in isolated locations, where connecting with the local power grid would be expensive. The demonstrated system, powered only by photovoltaic (PV) arrays with a battery backup, uses ceramic anodes and includes a satellite-based remote-monitoring capability. This system provides uniform and reliable CP in the water tanks interior below the water line. Data collected by the remote monitoring system can be loaded into a spreadsheet, and performance can then be analyzed on a pass-fail basis. The installed PV-powered CP systems operate as designed and conform to National Association of Corrosion Engineers (NACE) Standard Practice (SP) 0169 criteria. It is expected that little maintenance will be needed to keep the system operating properly. Required maintenance will include periodic cleaning of solar arrays and monthly recording of electrical output using a digital meter. Once every year, a qualified CP specialist should survey the system to ensure proper CP levels.

Michael J. White. PWTB 200-1-140. Terrain and The Physical Environment: Factors for Noise Mitigation, http://www.wbdg.org/ccb/ARMYCOE/PWTB/pwtb 2001 140.pdf

Army training involves live-fire and ordnance activities that generate high-amplitude sound and potential restrictions on training areas. Army installations are faced with new requirements and must rapidly adapt to control noise without impacting mission. In addition, highamplitude sound can pose risks to soldier health, disturb wildlife, and provoke civil affairs issues with surrounding communities. 
This PWTB offers assistance with these challenges by explaining both the physical effects of terrain on sound propagation and the use of digital terrain maps when preparing noise assessments. With the increasing availability of digital terrain maps, it is now possible to consider the role of terrain when preparing noise contours for military installations with live-fire training and demolition activities. It is difficult, however, to anticipate whether the terrain in the vicinity of an installation will be of benefit for noise shielding, and whether attention given to the question will change the noise assessment. This PWTB helps to overcome this assessment dilemma by outlining steps to using terrain maps with noise analyses software. The information in this PWTB is primarily for the graphical information system (GIS) specialist who may be tasked with preparing such an assessment. However, the material also provides general guidance on how to interpret noise contours that may be useful to urban planners, land managers, and others interested in knowing more about training range noise.

\section{Dongsheng Mao, Igor Pavlovsky, Richard L. Fink, et al. ERDC/CERL TR-15-6. Multifunctional Nanocomposites for Improved Sustainability and Protection of Facilities, http:/lacwc.sdp.sirsi.net/client/en_U.S./search/asset/1043506 ERDC/CERL TR-15-6}

The U.S. Army makes worldwide use of high-performance ballistic resistant fiberglass composite panels for force protection and other applications. This widespread use creates a need for an improved panel material that offers better bullet resistance at a lighter weight while still meeting existing ballistic resistance standards. This work to solve the Army's need included conceiving, developing, and validating a new nanocomposite material that is made of epoxy resin blended with functionalized carbon nanotubes (CNTs) that exhibits highly improved flexural strength and electrical conductivity for improving ballistic resistance in lighter weight glass fiber reinforced polymer (GFRP) ballistic panels. In addition, this work tested various options for adding self-healing, CNT reinforcement, Electro Magnetic Interference (EMI) shielding, and self-decontaminating properties for GFRP panels. Results of separate studies included in this report are: loading panels with CNTs by using different mass fractions and functionalization methods; introducing a self-healing agent directly to the matrix or contained in embedded hollow glass fibers; using layers of proprietary CNT sheeting in the GFRP composite; testing the electromagnetic impulse (EMI) shielding effects of introducing conductive materials; and adding a biocide-containing coating to finished panels.

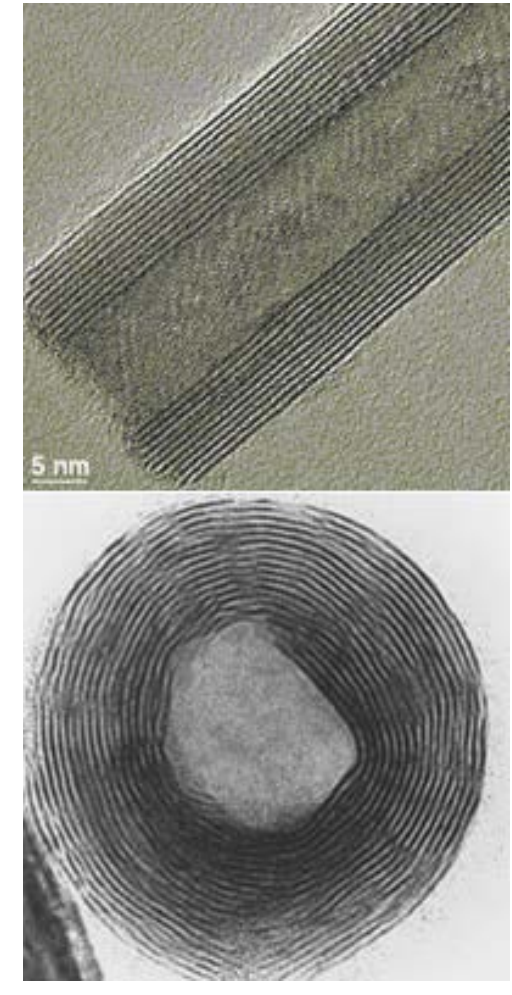

The unique structure of tungsten disulfide nanotubes make them remarkably strong and durable. 
Michael R. Kemme. ERDC/CERL TR-15-30. Developing Baselines for Prescribed Burning Smoke Management Plans and Best Management Practices,

http:/lacwc.sdp.sirsi.net/client/en_U.S./search/asset/1047387

Prescribed fire is a critical component of Army wildland fire management and prevention, range maintenance, and ecosystem management. The U.S. Environmental Protection Agency (USEPA) sets policy on controlling emissions from prescribed burning that is complex and still evolving. States have implemented USEPA regulations and policy by developing their own regulations, Smoke Management Programs (SMPs), and State Implementation Plan conditions. A wide array of guidance for developing SMPs is available, along with tools for managing prescribed fire emissions. The information in this report and many of the tools described here are applicable to Army installation management of prescribed burn smoke emissions. The Army already has the basic framework for developing SMPs within the installation-level Integrated Wildland Fire Management Plan that requires information on smoke management. However, this work discusses and recommends an approach for developing complete Army SMPs that align with the required elements of state/tribal SMPs. It is also recommended that a great deal of flexibility be allowed in the installation-level SMP to account for variation in

Failure to manage the Army's necessary prescribed burn programs could result in a variety of impacts that could directly affect vital training missions

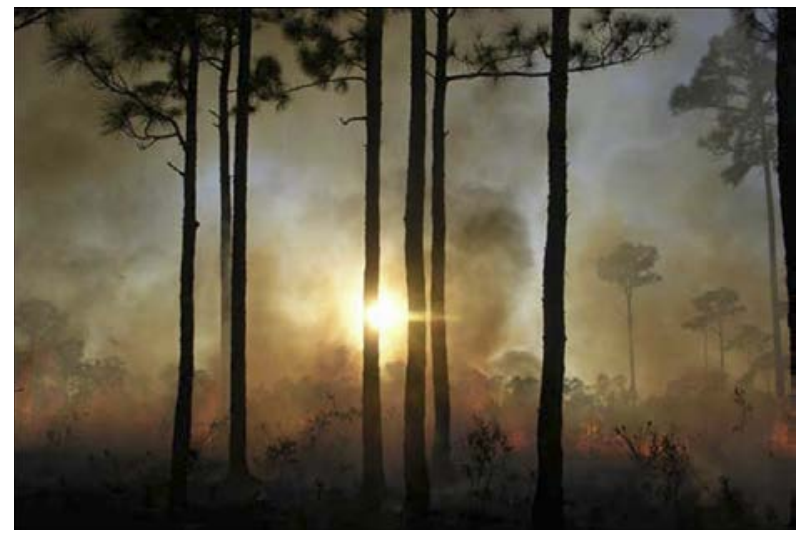
control smoke emissions and to meet state regulatory requirements.

Alfred D. Beitelman and Susan A. Drozdz. ERDC/CERL TR-15-12. [F10-AR01] Corrosion-Resistant Coatings for Air-Conditioning Coils and Fans, http:/lacwc.sdp.sirsi.net/client/en U.S./search/asset/1043986 DoD military installations operate air-conditioning equipment in humid and coastal locations that produce high levels of corrosion. Installation experience has shown that severe corrosion has reduced expected equipment life cycles by up to $50 \%$. This project for the Office of the Secretary of Defense Corrosion Prevention and Control Program demonstrated and evaluated the performance characteristics of two corrosion prevention coatings on condenser coils in highly corrosive environments. This work assessed the capabilities and advantages of an aluminum-impregnated polyurethane coating and a flexible epoxy polymer applied to two separate condenser units at Schofield Barracks, HI. The work also included fabricating and exposing test coupons of various substrates, each coated with the two coating systems and a third coating commonly used in less-corrosive environments. These coupons were exposed both at the Schofield Barracks site and in a laboratory-accelerated exposure cabinet. The work recommends that copper rather than aluminum components be specified in air conditioners operating in highly corrosive environments. A copper substrate protected with a newer type of corrosion coating is projected to extend the equipment's expected life cycle from 7-10 years to 25-30 years. The return on investment for the project is 3.89.

Steven D. Hart, J. Ledlie Klosky, Scott Katalenich, et al. ERDC/CERL TR-14-14. Infrastructure and the Operational Art: A Handbook for Understanding, Visualizing, and Describing Infrastructure Systems, http://acwc.sdp.sirsi.net/client/en_U.S./search/asset/1036581

The Army's understanding of infrastructure as an operational variable has been evolving over the past 30 years in response to significant events ranging from international conflicts to domestic weather-related disasters. These experiences have combined to drive a significant shift in infrastructure doctrine, which now demands that commanders and staffs understand, visu- 
alize, and describe the infrastructure variable to accomplish the Army's assigned infrastructure missions of protecting, restoring, and developing infrastructure-all missions essential to restoring stability after conflict or disaster. Current Army doctrine, however, does not say how commanders and staffs are to approach these challenging tasks. This report presents a cognitive framework for understanding, visualizing, and describing infrastructure by using five conceptual models created to allow commanders and staffs to think critically, creatively, and completely about infrastructure problems. The report also includes the scholarship behind the models including verification, validation, and certification as well as example applications of the models to actual situations. Infrastructure is a concern for both civil society and the military, and the models work equally well in both. The authors actively solicit feedback from any reader on the use, application, and improvement of these models.

Heidi R. Howard. PWTB 200-1-139. Evaluation of Demonstrated Bioswale, http://www.wbdg.org/ccb/ARMYCOE/PWTB/pwtb 200 1 139.pdf

Bioswales are wide, shallow, vegetated channels that use bioretention media (sand, gravel, and/or engineered media) beneath the surface to help improve water quality. Bioswales enhance water quality by capturing and infiltrating stormwater from the drainage shed, which also helps reduce stormwater runoff and side-channel erosion. This PWTB introduces bioswales and bioretention basins as LID practices and describes their purpose, design considerations, benefits, and implementation. In 2012, a bioswale was installed at Fort Hood, TX to demonstrate installation, maintenance, and stormwater management benefits of the technology when used in areas with low permeability soils. Lessons learned from the demonstration are documented in this PWTB. This PWTB documents lessons learned from the demonstration project.

Heidi R. Howard. PWTB 200-1-149. Demonstration of a Modular Wetland Treatment System for Stormwater Runoff, http://www.wbdg.org/ccb/ARMYCOE/PWTB/pwtb_200_1_149.pdf

Constructed wetlands can be a low-tech, low-cost, effective method to reduce the amount of pollutants in wastewater and stormwater discharges. Constructed wetlands are designed to mimic nature by increasing retention time through a series of biological, chemical, and physical methods that remove and reduce pollutants of concern. When used together, these methods constitute a "treatment train" that optimizes efficiency and space requirements. This PWTB documents the testing and evaluation of a commercially available LID technology, "Modular Wetlands "TM" (MWS), to slow down and treat stormwater runoff, thus preventing contaminant migration to surface water. This report describes the performance of the technology over 1 year and evaluates the effectiveness of the technology to provide a treatment train for a high-use paved area with heavy pollutant loads. It also includes results of the treatment system for in situ treatment of Petroleum, Oils, and Lubricants (POL), heavy metals, and suspended solids from polluted stormwater runoff, along with maintenance requirements for the system.

Heidi R. Howard. PWTB 200-1-138. Evaluation of Centralized Vehicle Wash Facilities for Invasive Species Removal, http://www.wbdg.org/ccb/ARMYCOE/PWTB/pwtb 200 1 138.pdf

Over 50,000 non-indigenous, exotic, alien, noxious, weed, or pest species (i.e., non-indigenous invasive species [NIS]) have been found in the United States. Many of these were originally introduced as crops, livestock, landscape materials, biological pest control, sport, pets, and/or food. NIS can affect human health and safety, and can be destructive to native ecosystems, agriculture, and infrastructure. DoD owns and manages large tracts of land (25 
million acres), and must reduce the risk of introducing or transporting NIS in CONUS and Outside Continental United States (OCONUS) locations. This PWTB discusses and quantifies lessons learned from a review of the use of low-pressure, high-volume (LPHV) water cannons and high-pressure, low-volume (HPLV) wands to compare the different systems' efficiencies in removing propagules (roots, stems, leaves, etc.) of NIS from military vehicles.

\section{Daniel Koch, James Westervelt, Andrew Fulton, et al. ERDCICERL TR-14-12. OPAL Netlogo Land Condition Model: Application and Validation at Fort Riley, $K S$,} http:/lacwc.sdp.sirsi.net/client/en US/search/asset/1035944

Proper management of military training lands is critical to ensure availability of training lands to ensure mission readiness. However, installation land management practices often support a broader mission than simply maintaining the land in a condition suitable for training; they also help installations to meet environmental requirements. The Optimal Allocation of Land for Training and Non-Training Uses Program (i.e., Optimal Programming of Army Lands [OPAL]) was developed to provide a systematic approach to enable military land managers and trainers to estimate biomass responses to training/management scenarios (training, mowing, and burning). This report documents a field validation of the OPAL model at Fort Riley, KS, and makes recommendations for system improvement.

OPAL team measuring above and below-ground biomass after treatments at Fort Riley, KS.

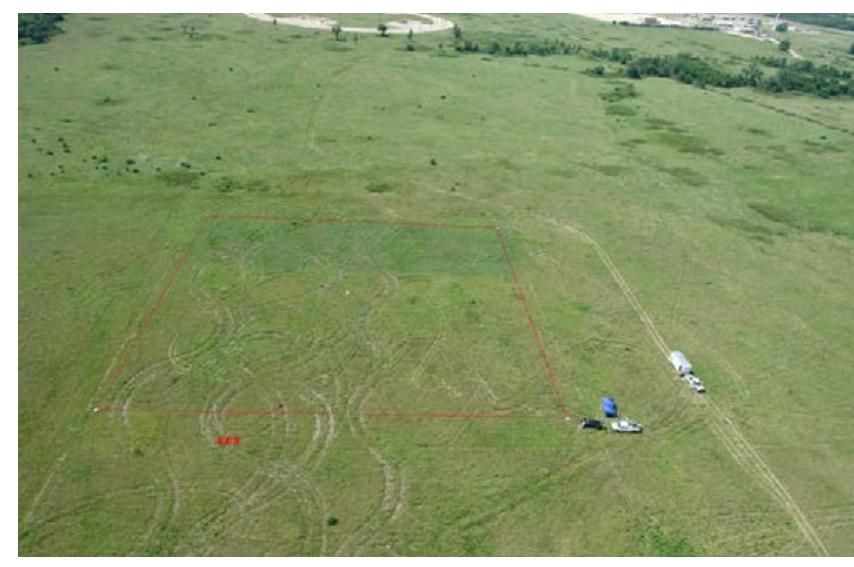

Alfred D. Beitelman and Susan A. Drozdz. ERDC/CERL TR-14-10. [F10-AR08] Demonstration and Validation of Vinyl Coating Systems for Cold Locations, http:/lacwc.sdp.sirsi.net/client/en U.S./search/asset/1035941

Cold-weather paint application to prevent corrosion of steel structures is expensive because it usually requires the construction of heated containment structures to ensure successful results. The Corps of Engineers V-776e solution vinyl paint formulation can be applied at low temperatures, but its VOC content exceeds regulatory max-minimum level, so permissible applications of it are highly restricted.

This report documents the demonstration and validation of a new low-VOC solution vinyl coating material that is based on the Corps of Engineers $\mathrm{V}-766 \mathrm{e}$ formulation. This material, called formulation V-766-LVOC, meets the regulatory VOC limit and can be applied to steel structures in low temperatures without heated containment. The demonstration coating was applied to a Bailey-type bridge on the Yukon Training Range at Fort Wainwright, AK. The corrosion performance and applicability results were considered to be comparable to the restricted V776e formulation, and application operation costs were lower than those for a conventional oil/alkyd formulation that would require heated containment. The return on investment (ROI) for this technology, including demonstration project management costs, was calculated to be 0.6 ; in a real-world project that includes only paint materials and application costs, the ROI becomes 2.85 .

David M. Bailey, Tarek Abdallah, Karl Palutke, et al. ERDC/CERL TR-14-1. [F09-AR04] Demonstration of a Corrosion-Resistant Roof System with Integrated Photovoltaic Power System, http:/lacwc.sdp.sirsi.net/client/en U.S./search/asset/1035941

This report documents the demonstration of a self-adhering, thin-film photovoltaic (PV) technology applied to a new aluminum-zinc coated standing-seam metal roof (SSMR) with a high-performance coating at Kilauea Military Camp (KMC), HI, which has a uniquely corrosive environment due to the periodic presence of volcanic gases. It also has high electric utility costs and limited grid capacity. The corrosion performance of the roof and PV solar 
array was evaluated by periodic visual examination, onsite atmospheric coupon testing, and accelerated weathering laboratory tests of material coupons. Sensors were also installed at the interface between the PV membrane and roofing material, mounted in outdoor exposure at the site, to record any developing signs of corrosion. After a year in service, the PV appliqué modules were found to have no deleterious effect on the new SSMR, and the PV system performed as expected. However, due to the high first-costs related to procuring the thinfilm PV components, the 30-year ROI ratio was only 0.19 . Although the system is not economical enough to warrant Army-wide implementation, it may be specified in individual cases where energy sustainability is a higher priority than ROI.

\section{Susan I. Enscore and Julie L. Webster. ERDC/CERL TR-15-34. Inventory and Evaluation of Buildings in the Industrial Area, Cape Canaveral Air Force Station, http:/lacwc.sdp.sirsi.net/client/en US/search/asset/1047889}

This report inventories all of the buildings and structures constructed at the Industrial Area, Cape Canaveral Air Force Station, FL, between the years of 1951 and 1968, not previously documented by the installation. Determinations of Eligibility to the National Register of Historic Places (NRHP) are then made based on the significance of the buildings and the degree to which they retain their physical integrity for conveying that significance. It was determined that 19 of the 85 buildings or structures inventoried and evaluated for this study were eligible for inclusion in the NRHP individually (two facilities) or as part of a historic district related to missile testing, missile assembly, and man in space significance themes. The period of significance for these buildings and structures is the Cold War Era, dating from 1951-1991. It was determined that 66 facilities are considered not individually eligible and non-contributing to the historic district due to either lack of significance or lack of integrity.

A further 15 previously surveyed buildings were evaluated for inclusion in a proposed Cape Canaveral Air Force Station Industrial Area Historic District (CCAFSIAHD). Of these properties, four buildings were previously determined eligible individually for inclusion in the NRHP. This survey recommends their inclusion in the proposed CCAFSIAHD, along with five other previously surveyed facilities that have now been determined to be contributing properties. Thus, a total of 27 facilities are recommended to be included in the CCAFSIAHD. Additionally, there is one facility determined individually eligible but outside the historic district.

Susan I. Enscore, Carey L. Baxter, George W. Calfas, et al. ERDC/CERL TR-14-11. Regional Analysis of Historic Farmstead Archeological Site Characteristics on DoD Installations, http://acwc.sdp.sirsi.net/client/en U.S./search/asset/1040422

The Army is tasked with managing the cultural resources on its lands. For installations that contain large numbers of historic farmsteads, meeting these requirements through traditional archeological approaches entails large investments of personnel time and organization capital. Through a previous project, Fort Leonard Wood and ERDC-CERL cultural resource management personnel developed a methodology for efficiently identifying the best examples of historic farmstead sites, and also those sites that are least likely to be deemed eligible for listing on the NRHP. This report details testing the applicability of the Fort Leonard Wood methodology to another region of the country. The Southeastern United States provided a temporal depth different from the earlier Ozark regional application. A historic context and determination of the "typical" farmsteads of the Southeast were developed. The Eligibility Prescreening Form created by ERDC-CERL researchers was modified to reflect the archeological patterns of the Southeast and then applied to test sites at Fort Bragg. The results of the fieldwork show that this approach is applicable to the Southeastern region, and that it can be used to quickly identify basic information about historic farmstead sites that can expedite determinations of eligibility to the National Register. 
Adam D. Smith and Megan W. Tooker. ERDC/CERL TR-15-31. The Army and the FHWA Program Comment for Common, Post-1945 Concrete and Steel Bridges,

http:/lacwc.sdp.sirsi.net/client/en_US/search/asset/1047867

This document presents an analysis of the applicability of the Advisory Council on Historic Preservation's Program Comment for Common Post-1945 Concrete and Steel Bridges with the Federal Highway Administration in regards to Armyowned bridges. The Program Comment eliminates "individual historic review requirements under Section 106 of the National Historic Preservation Act for common post- 1945 concrete and steel bridges and culverts" for the Federal Highway Administration (FHWA) in certain cases. The Program Comment can be used for post-1945 bridges owned by Fort Knox, KY Bridge 04 in 2013

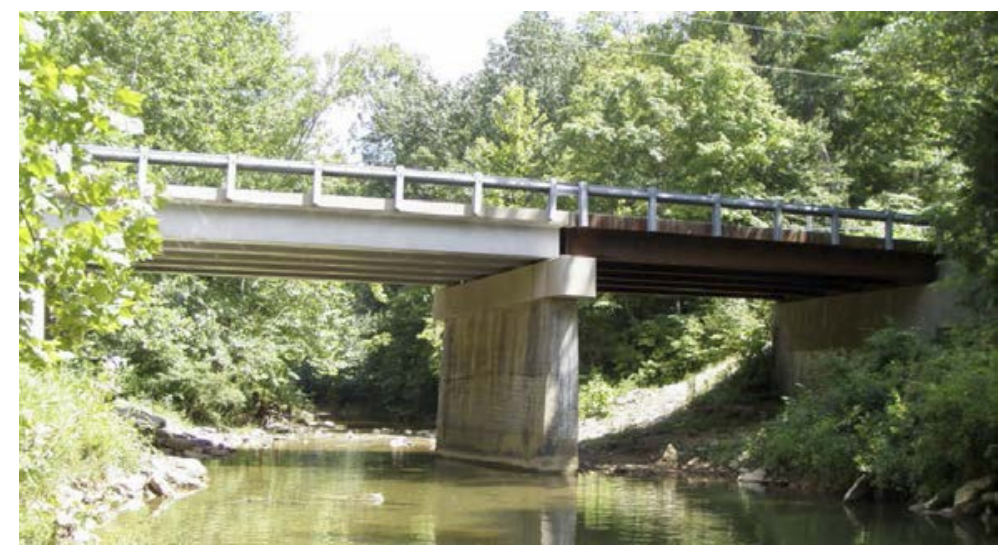
other federal agencies under certain circumstances. It was the determination of the authors of this report that the Army would gain no significant benefit by using the existing Program Comment for Common Post-1945 Concrete and Steel Bridges, but it may benefit the Army to request a program comment of its own from the Advisory Council on Historic Preservation to cover post- 1945 concrete, steel, and wood bridges.

\section{Smith. Draft ERDC/CERL SR. Architectural Survey of Ohio Army National Guard Properties: Volume I - Main Report.}

This document is Volume 1 of a two-volume architectural survey of 85 buildings and structures used by the Ohio Army National Guard and located across the state of Ohio. The majority of these structures were constructed between 1920 and 1968, with others constructed from 1969 to 1988. This survey satisfies Section 110 of the National Historic Preservation Act of 1966 as amended, and was used to determine the eligibility of these buildings and structures for inclusion on the NRHP. It is the recommendation of this report that 14 armories are significant under NRHP criteria and that they retain enough integrity to be individually eligible for the NRHP. Volume II of this report is published separately and contains the architectural survey forms.

\section{Susan I. Enscore, Adam D. Smith, and Megan W. Tooker. ERDC/CERL TR-15-25. Camp Sherman, Ohio: History of a World War I Training Camp, http://acwc.sdp.sirsi.net/client/en US/search/asset/1047630}

This document presents a historic context, integrity analysis, and evaluation for the NRHP of the World War I era rifle range at the Camp Sherman J oint Training Center, Ohio. The report meets the requirements in the National Historic Preservation Act (NHPA) for federal agencies to address their cultural resources-defined as any prehistoric or historic district, site, building, structure, or object. Identification of potentially significant properties is achieved only through a survey and evaluation to associate a property within a larger historic context. The Camp Sherman Rifle Range was constructed in 1917 for training soldiers in preparation for deployment to European battlefields. This function only lasted until the 1918 Armistice, but the range has been used by the Ohio Army National Guard for training over the decades since. It is the recommendation of this current survey that the 452-acre Camp Sherman Rifle Range (Camp Sherman J oint Training Center) be recommended not eligible to the NRHP due to a significant loss of integrity. 
Adam D. Smith, Susan I. Enscore, and Megan W. Tooker. ERDC/CERL TR-14-29. William Barstow Mansion of The United States Merchant Marine Academy: Nomination to the National Register of Historic Places, http:/lacwc.sdp.sirsi.net/client/en_U.S./search/asset/1040640

Congress codified the NHPA to provide guidelines and requirements for preserving tangible elements of the nation's past. This was done primarily through the creation of the NRHP. Through Sections 110 and 106 of the NHPA, federal agencies are required to address their cultural resources, which are defined as any prehistoric or historic district, site, building, structure, or object. This document contains the nomination form and all supporting documentation for listing the William Barstow Mansion property, located at 300 Steamboat Road, Kings Point, in Nassau County, NY, on the NRHP. The property is considered historically significant on a statewide level as a reminder of the "Golden Age" of the late nineteenth and early twentieth centuries. The property consists of two contributing features-the William Barstow Mansion and garage-which retain their integrity from the period of significance, 1915-1960. The property is part of the McNulty Campus of the U.S. Merchant Marine Academy and currently serves as the American Merchant Marine Museum. It was listed on 29 August 2014 as NRHP \#14000539.

Adam D. Smith, Susan I. Enscore, and Megan W. Tooker. ERDC/CERL TR-14-28. United States Merchant Marine Academy Historic District: Nomination to the National Register of Historic Places, http:/lacwc.sdp.sirsi.net/client/en U.S./search/asset/1040601

Congress codified the NHPA, to provide guidelines and requirements for preserving tangible elements of the nation's past. This was done primarily through the creation of the NRHP. Through Sections 110 and 106 of the NHPA, federal agencies are required to address their cultural resources, which are defined as any prehistoric or historic district, site, building, structure, or object. This document contains all supporting documentation and photos for the nomination of the U.S. Merchant Marine Academy (USMMA) Historic District to the NRHP. The USMMA is the nation's only federally-owned educational facility for the advanced training of merchant mariners. This work determined the USMMA Historic District has two periods of significance: 1912-1941 (Gold Coast Era) and 1942-1969 (USMMA Design and Development). The 42-acre district consists of a contributing landscape and 38 contributing buildings, structures, and objects. The district is historically significant on a national level under National Register Criterion A as a reminder of the "Golden Age" of the late nineteenth and early twentieth centuries. Criterion $C$ is met through the design of the buildings that survive on the district's grounds. The district was listed by the NRHP in August 2014 as \#14000538.

\section{Adam D. Smith and Sunny E. Adams. ERDC/CERL SR-14-6. Matthew Jones House: Historic Maintenance and Repair Manual, http:/lacwc.sdp.sirsi.net/client/en U.S./search/asset/1040600}

The Matthew J ones House is located on J oint Base Langley-Eustis (Eustis), VA. The house is a Virginia Historic Landmark (121-0006) and also listed on the NRHP (\#69000342). The house is now being used as an architectural-study museum with 90 architectural features labeled as teaching points. The structure illustrates the architectural transition from the post-medieval vernacular to the Georgian style to the Victorian style. All buildings, especially historic ones, require regular planned maintenance and repair. The most notable cause of historic building element failure and/or decay is not the fact the historic building is old, but rather it is caused by an incorrect or inappropriate repair and/or basic neglect of the historic building fabric. This document is a maintenance manual compiled with as-is conditions of construction materials of the Matthew J ones House. The Secretary of Interior 
Guidelines on rehabilitation and repair per material are discussed to provide the cultural resources managers a guide to maintain this historic building. This report satisfies Section 110 of the NHPA of 1966 as amended and will help the J oint Base Langley-Eustis, Fort Eustis Cultural Resources Management to manage this historic building.

Adam D. Smith. ERDC/CERL SR-14-3. Fort Leonard Wood Building 2101: Interior CharacterDefining Features, Inventory and Assessment, http:/lacwc.sdp.sirsi.net/client/en U.S.Isearch/asset/1034801 This document is an inventory and assessment of character-defining features for the interior of Building 2101 (former Black Officers' Club) at U.S. Army Garrison Fort Leonard Wood, MO. This survey satisfies Section 110 of the NHPA of 1966 as amended, and it was used to determine which elements of the interior of the building are character-defining features from the period of significance (World War II era). Building 2101 was determined eligible for the NRHP in 2003.

Adam D. Smith, Susan I. Enscore, and Sunny E. Adams. ERDC/CERL SR-14-5. Character-Defining Features of Contributing Buildings and Structures in the United States Merchant Marine Academy Historic District. (Publication pending.)

This report documents an architectural survey of character-defining features for the contributing features of the US-

Mural painted by Samuel Countee, placed above the German POW fireplace on the main floor of Bldg. 2101

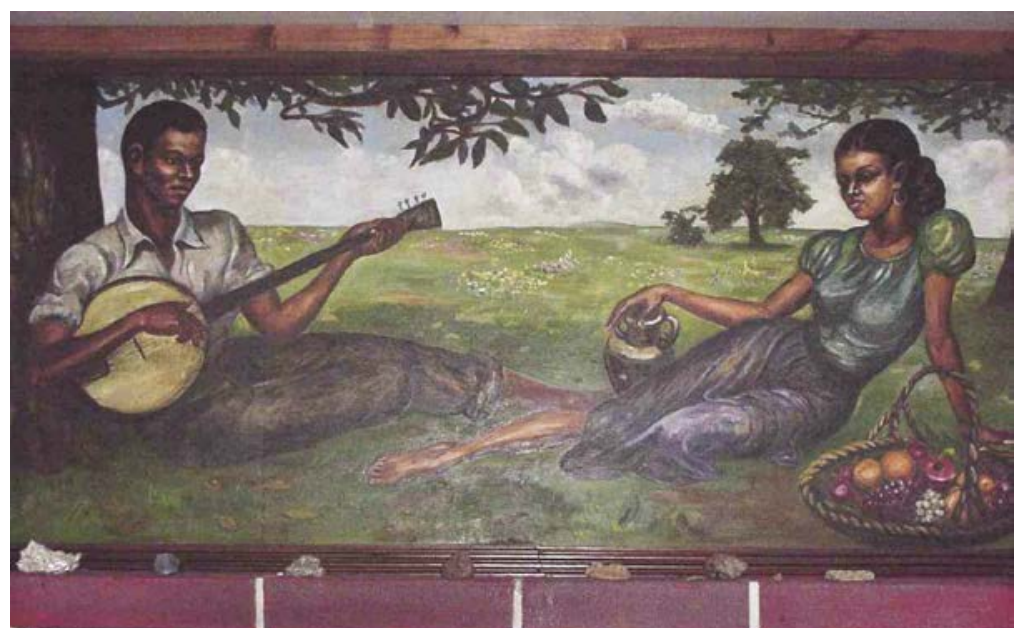
MMA Historic District. This survey satisfies Section 110 of the NHPA of 1966 as amended, and was used to determine the elements of the buildings and structures of the historic district that are character-defining features for the elements that are eligible for the NRHP.

Adam D. Smith. Draft ERDC/CERL TR. Cultural Landscape Analysis of Existing Historic Districts: Picatinny Arsenal, New Jersey.

This study documents the cultural landscape at Picatinny Arsenal, focusing on five existing historic districts. This work looks at the historic development and discusses the existing conditions within each of the five districts. It analyzes the features within each district for their historic significance and integrity, and based on this analysis, makes treatment recommendations. This document meets the requirements for federal agencies to address their cultural resources that are defined as any prehistoric or historic district, site, building, structure, or object. Especially relevant is Section 110 of the NHPA, which requires federal agencies to inventory and evaluate their cultural resources.

Adam D. Smith. Draft ERDC/CERL SR. Architectural Survey at Joint Base Langley-Eustis of Fort Eustis Buildings and Structures Built 1946-1975: Volume I.

This document is an architectural survey of 125 buildings and structures located J oint Base Langley-Eustis (Eustis), VA, constructed from 1946-1975, for the eligibility to the NRHP. This survey satisfies Section 110 of the NHPA of 1966 as amended, and was used to determine the eligibility of these buildings and structures for inclusion on the NRHP. This report recommends that survey that only Building 415 (Landship Training Facility) is significant and retains enough integrity to be individually eligible for the NRHP. 
Victor F. Medina. ERDC WQTN-MS-9. Evaluation of Environmentally Acceptable Lubricants (EALS)

for Dams Managed by the U.S. Army Corps of Engineers,

http:/lacwc.sdp.sirsi.net/client/en_US/search/asset/1045297

This technical note reports on a study undertaken to provide a preliminary assessment of EALs for application in dams managed by the U.S. Army Corps of Engineers (USACE). The assessment explores the environmental aspects of these lubricants and also discusses their operational characteristics. The assessment was done primarily through the literature available on this topic, and includes interviews with various experts.

Pintle gate bearing (from the Rock Island Dam, Rock Island, IL) and a self-lubricating bushing from the Dalles Dam, which spans the Columbia River between Washington state and Oregon.
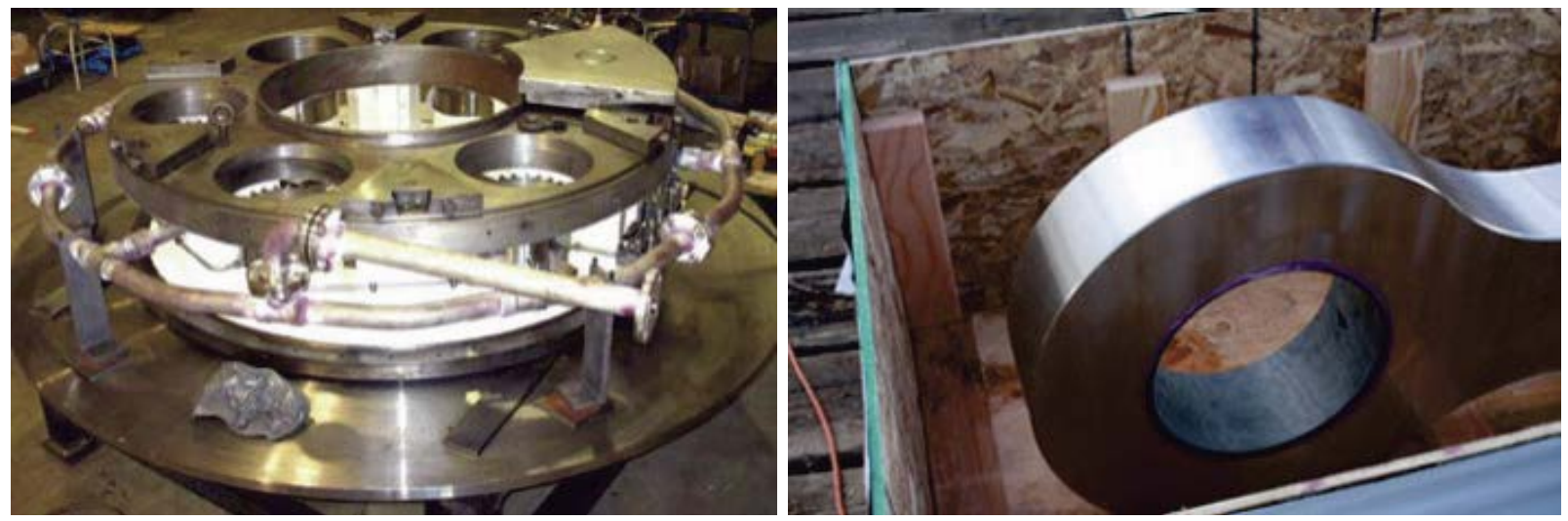

Rosa T. Affleck, Jeanne M. Roningen, Jennifer S. Macpherson, et al. 2015. ERDC TR 15-10. Analysis of Operational Data: A Proof-of Concept for Assessment of Electrical Infrastructure Impact, http:/lacwc.sdp.sirsi.net/client/en U.S./search/asset/1047529

Infrastructure variables required for a community or society to function include basic facilities, services, and installations; and these variables can impact many aspects of daily life. The structure and functionality of the electrical grid in an operating area can affect multiple operational variables. Other infrastructure sectors that rely on the electrical grid can fail when electricity is disrupted. Thus, the impact of electricity in a society is vital for prosperity and security and expands the broad impact on economic and social well-being.

This study used remote-sensing data to examine the electrical system and power-grid functionality for Dhaka, Bangladesh. The focus of this work was on the transmission and distribution networks, the network patterns, and the electrical capacity. In addition, the pattern of a power outage (i.e., the 1 November 2014 blackout) and the duration The change in standardized radiance between the early morning prior to and following the blackout. Red areas indicate increase radiance, and blue areas indicate decreased radiance.

of the outage were used to assess the affected neighborhood and the power-production disruptions at other major power stations within the country. When the Visible Infrared I maging Radiometer Suite (VIIRS) data were combined with the panchromatic sharpening of WorldView-2 imagery, it became possible to focus on the affected areas, thereby narrowing the search for electrical-grid components. This study is an example for understanding the dynamic physical environment relevant to military operations. 
Jason Weale, Lynette Barna, Wayne Tobiasson, et al. 2014. ERDC/CRREL TR-14-2. Elevated Building Lift System in Polar Environments Workshop,

http:/lacwc.sdp.sirsi.net/client/search/asset/1036543

The National Science Foundation sponsored this 2-day workshop to bring together international experts to discuss the history and state-of-the art of systems used to periodically lift elevated buildings constructed on permanent snowfields. Early structures permanent snowfields were typically built at the surface and became buried over time from accumulating snow. These buildings were prone to short service lives as the accumulating snow increased pressure on the structures, eventually rendering them unsafe. An accepted current practice for constructing most structures on permanent snowfields is to elevate them above the natural terrain. This technique reduces the adverse effects of annual snow accumulation, snow drifting, and snow settlement and prevents thawing of the snow foundation from the heated superstructure. To achieve costeffective service lives, there is extra incentive to periodically lift the elevated structures and to maintain them above the ever-rising snow surface. This report summarizes lift systems used to maintain the current generation of elevated, permanently occupied polar stations above permanent snowfields.

Construction of the steel framed elevated structures on site.

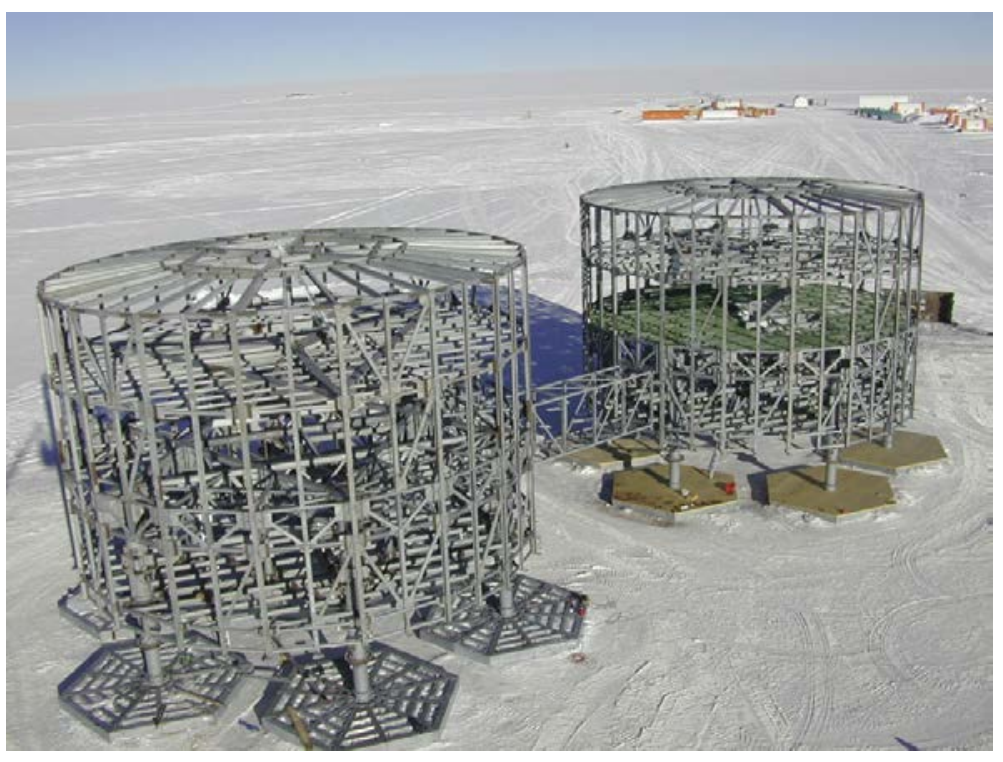

Rosa Affleck and Meredith Carr. 2014. ERDC/CRREL SR-14-3. Preliminary Guidelines and Standard Operating Procedure for Drainage and Erosion Control at McMurdo Station, http://acwc.sdp.sirsi.net/client/search/asset/1040864

During the austral summer, the snowmelt runoff at McMurdo Station is quite unique and variable. As the temperature gradually warms up, McMurdo staff clears winter snow and ice accumulation in the drainage channels to accommodate the incoming snowmelt runoff. This ephemeral flow is observed as diurnal daily fluctuation throughout the austral season and varies depending on the air temperature and many other factors. In addition, the runoff mobilizes sediment that is washed into these channels and transports contaminants into Winter Quarters Bay and McMurdo Sound. This report provides guidance for the operation and maintenance of in-town roads and the drainage system. The processes and steps in this document require further verification to incorporate lessons learned and to promote appropriate McMurdo Station drainage system. best practices. 
Matthew Bigl and Elias Deeb. 2015. ERDC/CRREL TN-15-2. Site Assessment and Feasibility of a New Operations Base on the Greenland Ice Sheet: Addendum to the Preliminary Report, http://acwc.sdp.sirsi.net/client/search/asset/1047386

The New York Air National Guard (NYANG) 109th Airlift Wing training facility located at Raven in southwest Greenland experienced surface crevassing during the 2012 extreme Greenland melt event, which limited the use of the runway. Because of subsequent interest in relocating the run- way, this study analyzed the runway's climatic, physical, and logistical factors, expanding on Site Assessment and Feasibility of a New Operations Base on the Greenland Ice Sheet by Burzynski et al. (2013). Their report identified a primary target region for relocating the runway based on stakeholder criteria and climatic data collected from across Greenland. This work improved on this investigation by replacing the proxy (e.g., elevation) previously used for melt with newly released satellite estimates of melt. These new data used changes in microwave emissions from the surface and near surface of the Greenland Ice Sheet to estimate melt days across Greenland. By applying the Burzynski et al.

(2013) criteria to the new melt data, melt days/year were quantified over the past 35 years. This improves the selection criteria for an appropriate relocation zone for the Raven runway, and the ArcGIS framework developed by this project provides the ability to incorporate future stakeholder needs into the site-selection analysis.

Composite satellite maps of the Greenland 2012 melt event.

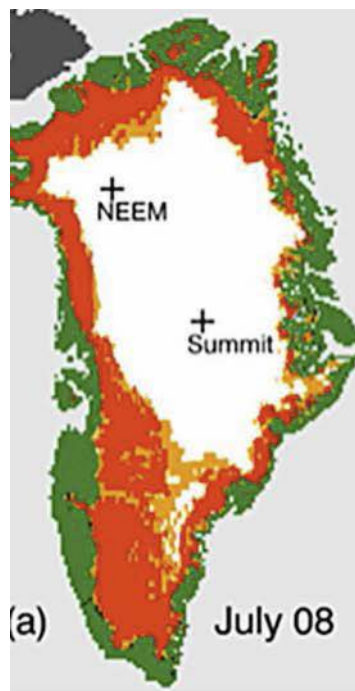

No melt
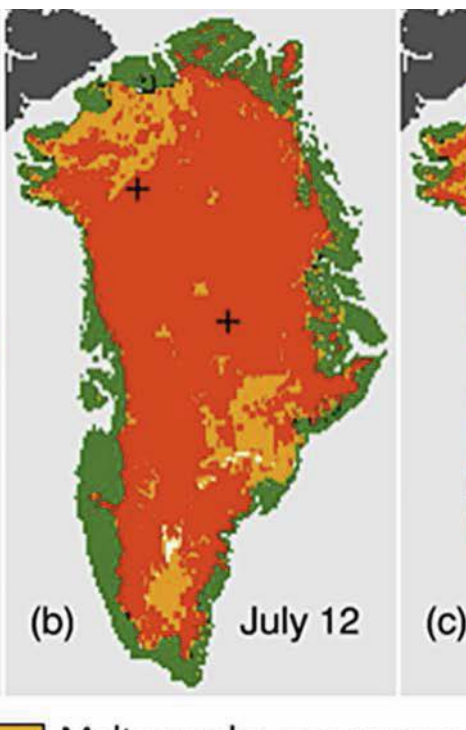

Melt seen by one sensor

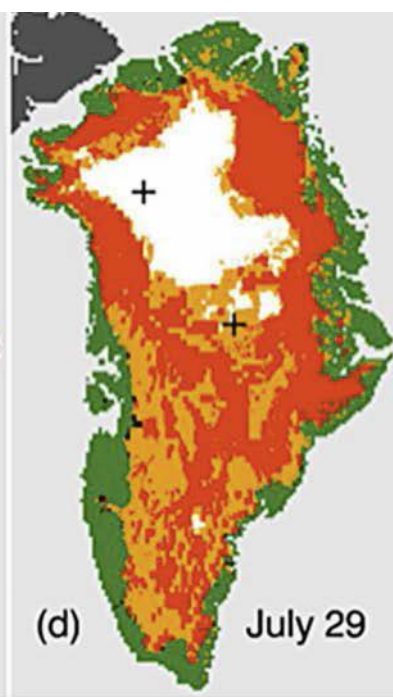

Melt seen by two or more sensors 
Anna M. Wagner. 2014. ERDC/CRREL TR-14-1. Review of Thermosyphon Applications,

http:/lacwc.sdp.sirsi.net/client/search/asset/1033420

Thermosyphons have been used for stabilizing permafrost since 1960. The original thermopile was designed as a vertical unit with one end buried in the ground and the other end exposed to the air. More recently, flat, loop, and buried thermosyphons have been developed. Thermosyphons consist of a pipe or series of pipes that are installed with one part below ground (evaporator) and the other exposed to the air (condenser). They are filled with a pressurized fluid that evaporates because of the heat of the soil and rises as a vapor to the condenser. If the air temperature is lower than that of the soil, the vapor will condense on the inside walls of the pipe and release the transported heat from the ground to the air. The condensate then returns to the evaporator by gravity. When the air temperature is higher than that of the soil, the heat transfer ceases and the unit is dormant. Presented here is a general overview of applications of thermosyphons in cold regions.

\section{Rosa T. Affleck, Meredith Carr, Margaret Knuth. 2014. ERDC/CRREL TR-14-6. Runoff Characteristics and Variations at McMurdo Station, Antarctica, http://acwc.sdp.sirsi.net/client/search/asset/1035040}

As the austral summer approaches, major flow arteries are manually cleared in anticipation of the ephemeral runoff during the summer months. This flow, primarily from snowmelt, has daily and seasonal fluctuations.

The flow fluctuation and variation depend on the air temperature and Extreme incident showing raging water from snowmelt (12 December 2007)

on many other factors. In addition, the runoff mobilizes sediment and localized soil contaminants that wash through these channels and discharge primarily into Winter Quarters Bay.

This report quantifies the runoff characteristics, including discharge correlations and variations for McMurdo Station drainage channels, and expands the understanding of the runoff characteristics at McMurdo Station. The flow data taken during austral summer 2010-11 combined with 2009-10 data fills the gaps in the analysis to quantify the runoff. Based on the

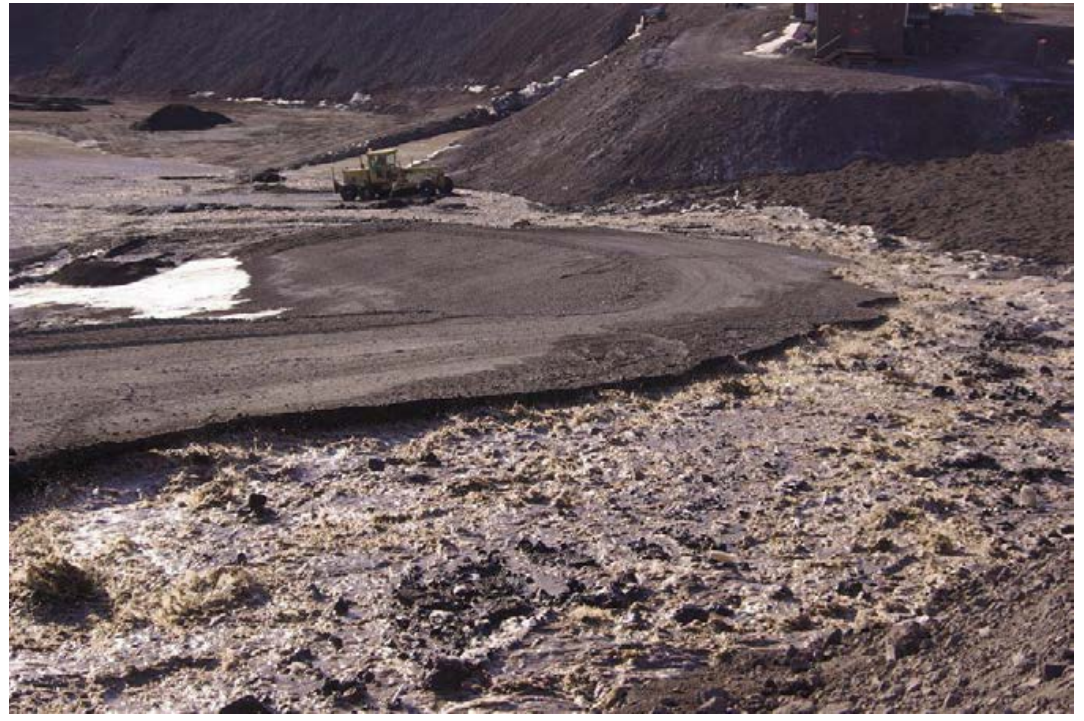
correlation between the change in accumulated thawing degree days and cloudiness expressed in clearness, the time delay in the peak discharge can occur between 4 and 14 days after a peak temperature. Based on the frequency and probability distribution of the flow, a flow greater than $0.33 \mathrm{~m}^{3} / \mathrm{s}$ in the major channel occurred less than $5 \%$ of the time during the season. This study provides critical information for planning, operation and maintenance, the design of preventive methods, and the application of best practices. 
Lynette A. Barna and Charles J. Korhonen. 2014. ERDC/CRREL TR-14-8. Extending the Season for Concrete Construction and Repair: Phase III-Guidance for Optimizing Admixture Dosage Rates, http:/lacwc.sdp.sirsi.net/client/search/asset/1035260

This project is the third installment of the program "Extending the Season for Concrete Construction and Repair" with the goal of advancing cold weather concreting capabilities. This manual includes the tools and general guidance needed to tailor the chemical admixture dosage rates of anti-freeze concrete mixtures to cure when exposed to ambient air temperatures near and below freezing. During cold weather, air temperature conditions vary constantly, influencing the internal hydration rate of the curing concrete. This study developed a one-dimensional thermal model, based on fundamental principles of heat transfer, to simulate curing concrete exposed to low or sub-freezing air temperatures. Data collected from a previous field study curing antifreeze concrete were used in the thermal model to evaluate the effects of curing temperature. The model gave good agreement with measured concrete temperatures. This study found that laboratorygenerated curves describing the internal heat generated in cement under steady-state conditions are not applicable for antifreeze concrete in winter weather. Additional heat signature curves are needed to better describe curing antifreeze concrete.

Sally A. Shoop, Margaret A. Knuth, Wendy L. Wieder, et al. 2014. ERDC/CRREL TR-14-9. Vehicle Impact Testing of Snow Roads at McMurdo Station, Antarctica, http://acwc.sdp.sirsi.net/client/search/asset/1035440

In December 2009, a study was conducted to determine

West Lebanon, $\mathrm{NH}$, bridge curb repair, completed in December 2002, using antifreeze concrete

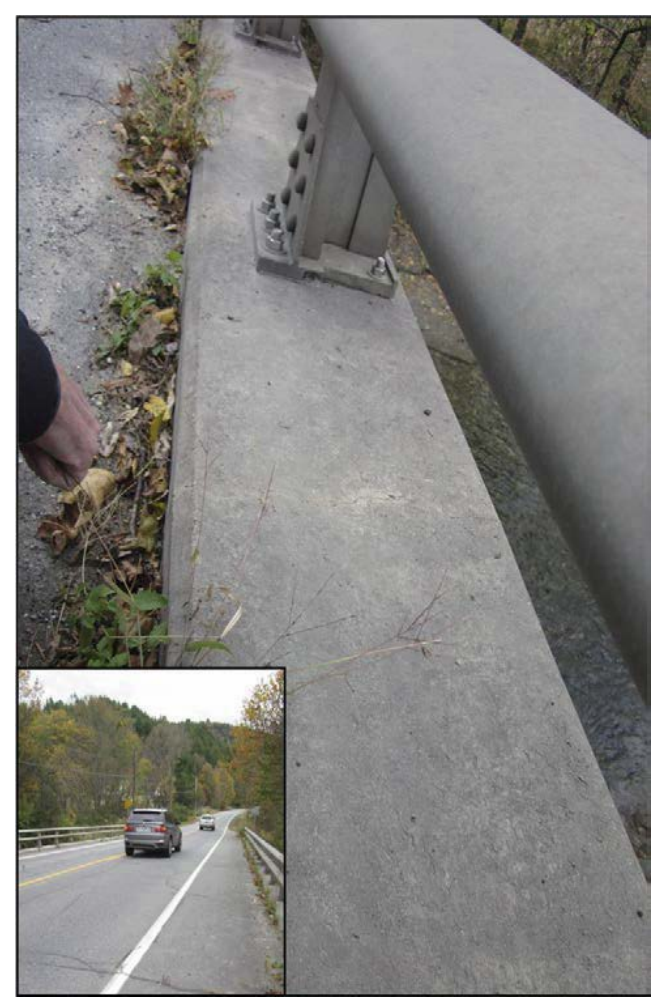
how vehicle operations impact snow roads. The snow roads at McMurdo Station are the primary transport corridors to move personnel and material from the air-fields servicing intraand inter-continental flights. Thus, they are a critical transportation component and are also particularly susceptible to deterioration during warm temperatures. This study explored methodology to quantify the impact of various vehicles, tires, driving speeds, and maneuvers on snow-road conditions. The specific impacts of turning, acceleration, braking, and

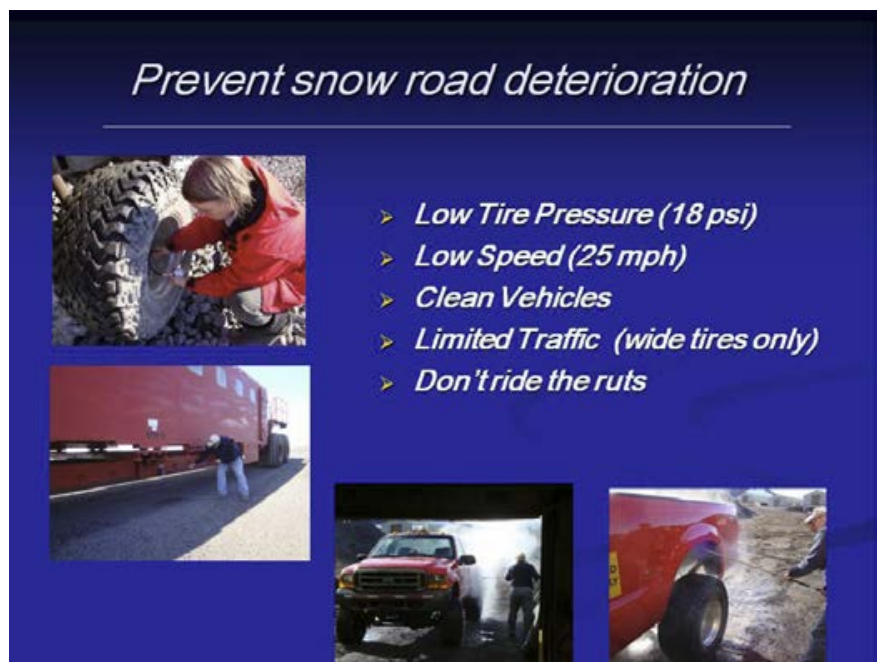
speed were isolated using spirals, circles, and straight-line testing on compacted snow surfaces. Portions of the active snow-road system were also used in a road course involving corners and surface roughness. Measurements included the strength of the snow surface in and between tire tracks, tire-track rut depth and width, and the height and width of the resulting snow piles adjacent to the tire tracks. The experiments yielded valuable guidance regarding what types of testing and measurements could most easily differentiate performance. Results indicate the impacts of driving speed and vehicle type, including the importance of the tire and suspension components, on preserving satisfactory snow-road surfaces through the melt season. 
Sally A. Shoop, Russ Alger, Joel Kunnari, et al. 2014. ERDC/CRREL TR-14-16. Evaluation of a New SnowPaver at McMurdo Station, Antarctica, http:/lacwc.sdp.sirsi.net/client/search/asset/1036362

The snow roads at McMurdo Station are the primary transportation corridors to the surrounding airfields. However, during warm spells, deteriorating road conditions can seriously limit payloads for all types of vehicles. CRREL has studied the construction and maintenance of the snow roads and teamed with the Keweenaw Research Center (KRC) and the National Science Foundation (NSF) to assess the feasibility of using a new SnowPaver to build snow roads in Antarctica. KRC built the SnowPaver, a single unit consisting of leveling blades, a milling unit, and a vibratory plate compactor, and shipped it to McMurdo in November 2010. In McMurdo, the SnowPaver constructed snow pavement sections that were monitored for performance based on snow-road strength and vehicle rutting. The SnowPaver was also used for reworking and compacting old and slushy snow during the height of the warm season. In November 2012, the power unit was upgraded; and snow roads built with the improved SnowPaver were 5 to 7 times stronger than the SnowPaver groomer, McMurdo Station (2010) unprocessed road and 3 to 4.6 times stronger than the Pegasus Road. An economic analysis showed the SnowPaver would pay for itself in 1 to 5 years, depending on the usage.

\section{Steven F. Daly, Meredith Carr, Kevin Bjella, et al. 2014. ERDC/CRREL TR-14-18. Development of Conceptual Designs for Prevention of Ice Formation in the Proposed Maple River Open Aqueduct, http://acwc.sdp.sirsi.net/client/search/asset/1036584}

The Fargo-Moorhead Metropolitan Area Flood Risk Management Project is to include an aqueduct to carry the flow of the Maple River over a proposed diversion channel. This study quantified the amount of ice that forms in the aqueduct under different winter operating scenarios. To achieve this, this study developed an aqueduct flow and ice simulation that simulated five different operation scenarios: the proposed aqueduct alone, a case with downstream stage control, and three different cases of applied heating. Each scenario was run with 6 in., 3 in., and no insulation on the outside of the aqueduct. The flow conditions and the ice formation in the aqueduct were simulated every day for the winters of 1995 to 2013, allowing estimates to account for the natural variability of the flow and air temperature. The simulation found that, though ice formation in all scenarios caused the stages to rise, the unheated scenarios saw the largest stage rise; and the impact of the insuPontcysyllte Aqueduct (3 December 2010) lation in the unheated scenarios was significant. Applying heat reduced stages compared to the unheated cases, the amount of heat applied determined the decrease in the upstream stages, and insulation had less impact when heat was applied. 
Robert Haehnel and John Weatherly. 2014. ERDC/CRREL TR-14-21. Antarctic Camps Snow Drift Management Handbook, http:/lacwc.sdp.sirsi.net/client/en U.S.Isearch/asset/1036640

Drifting snow on buildings, equipment, and tents at research camps throughout the Antarctic continent is a persistent problem. This handbook provides methods to estimate the severity of the drifting problem at a proposed or an existing camp location and methods to ameliorate the drifting problems.

The guidelines provided apply to camps where the wind is predominately from one direction, typical of a large percentage of the Antarctic continent where katabatic or down slope winds are dominant. The snowdrift protection methods outlined in this handbook do not suit regions where the storm winds can come from several dominant directions.

Also included is a case study to demonstrate application of the methods outlined for estimating the severity of the drifting problem and for properly sizing the snowdrift protection system. Additionally, it provides methods to estimate the volume of snow that can be deposited during a camp season and gives examples of how to estimate the level of effort required to install the protection systems and to manage the snow throughout the camp season.

Wyoming snow fence installed on the Ross I ce Shelf, McMurdo, Antarctica.

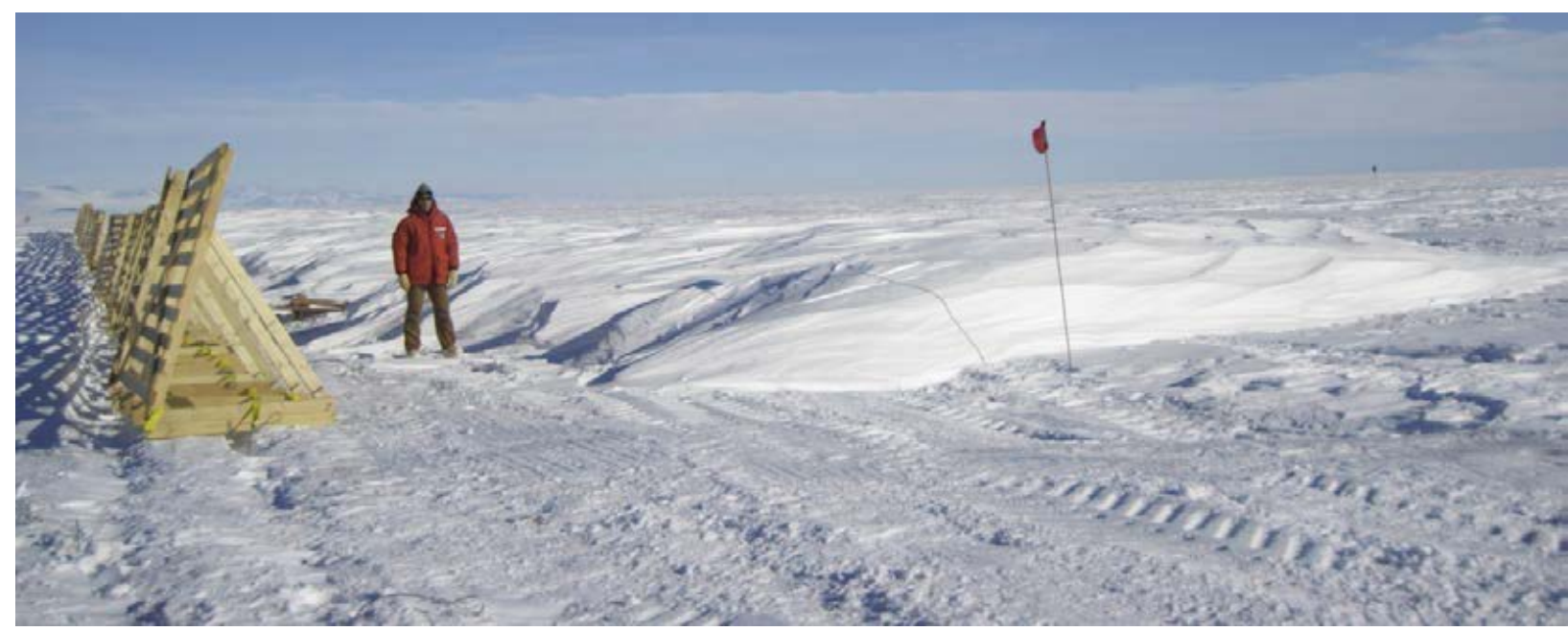

Robert Haehnel, Margaret A. Knuth, Terry Melendy, et al. 2014. ERDC/CRREL TR-14-22. Design and Implementation of a Consolidated Airfield at McMurdo, Antarctica, http://acwc.sdp.sirsi.net/client/search/asset/1036641

This report presents a consolidated airfield design for McMurdo, Antarctica. The design includes a single skiway for ski-equipped aircraft and a single runway for wheeled aircraft. Two possible locations for the new airfield are on glacial ice at the current Pegasus site or on a snow surface 4-5 miles NE of Pegasus. Final decision on the location requires balancing the need to locate the airfield outside the dust plume against the ability to establish on a snow surface a runway that supports wheeled aircraft. The current whiteout landing area would still serve the needs of the consolidated airfield; and Williams Field would continue to act as an emergency divert site for ski-equipped aircraft. 
A review of the runway support facilities shows that the number of buildings can be reduced from 27 to 14, reducing the size of the town site and the travel distance between functional elements. The consolidated airfield, including support equipment and facilities, will take about 7 years to complete. When complete, it will improve operational efficiency by consolidating services at a single location, eliminating movement of resources between two or more airfields, and allowing replacement of existing runway support buildings with more energy- and space-efficient designs.
I sometric view of the apron, taxiway, and town site area of the proposed consolidated airfield

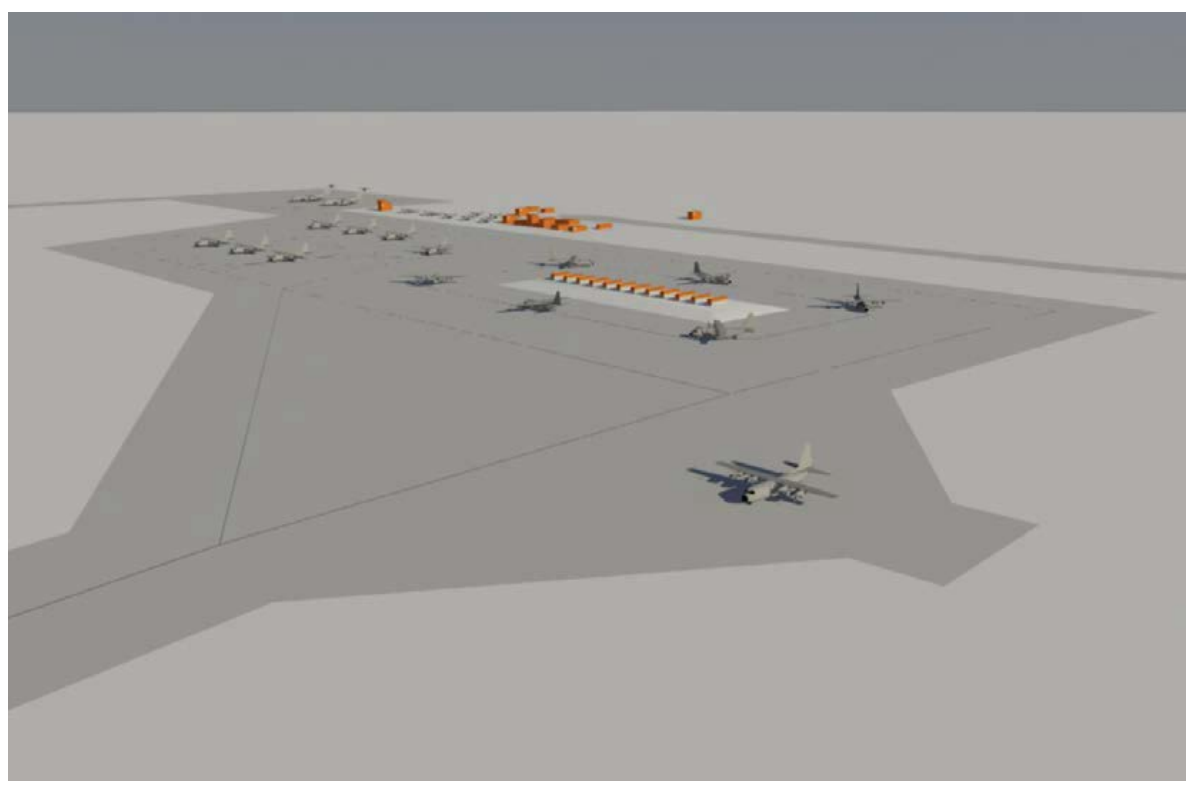

James H. Lever, Jason C. Weale, and Glenn Durell. 2014. ERDC/CRREL TR-14-24. Low-

Temperature Flex Durability of Fabrics for Polar Sleds,

http:/lacwc.sdp.sirsi.net/client/en U.S.Isearch/asset/1036740

Lightweight fuel-bladder sleds are remarkably efficient and less expensive than conventional steel sleds for Antarctic resupply traverses. However, a significant fraction of fuel bladders develop cracks after being emptied and folded for return transport and storage. This work conducted low-temperature flex-durability tests of existing and candidate bladder materials to understand the fold-cracking problems and to seek more durable materials. The fabric specimens underwent repeated cycles of severe twisting and folding at $-40^{\circ} \mathrm{C}$, after which the specimens were checked for leaks by using an air-permeability test. Remarkably, the existing bladder material could withstand hundreds of cycles before cracking and leaking, and it performed better than tested alternatives. It is possible that months-long folded storage of bladders causes stress-relaxation in the polymer coating at tight folds, and preseason unfolding then induces tensile cracking. In

The polymer-coated fabric used for prototype ARCS pouches was stiff to handle at low temperatures and tended to crack when flexed over rough snow.

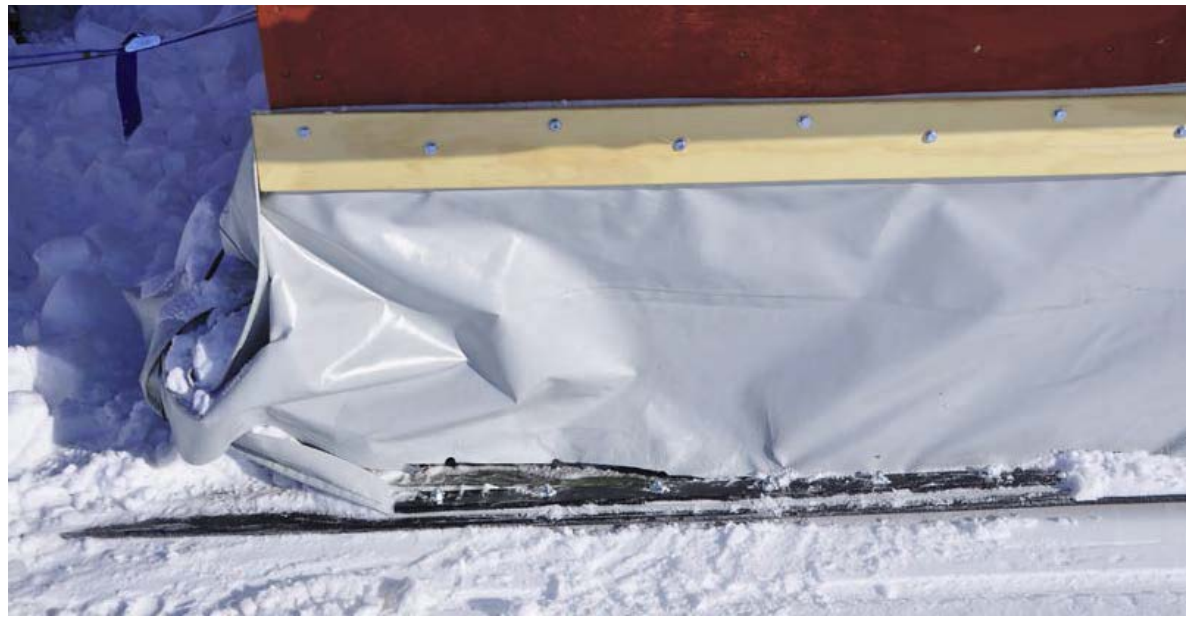

2013, the South Pole Traverse (SPoT) acted on this work's recommendation to transport and store empty bladders inflated. They reported very promising results: no leaks in bladders and shorter preparation times for sled reuse. The flex-durability tests also identified very durable materials to build enclosure pouches for air-ride cargo sleds (ARCS). ARCS have the potential to transport rigid and outsize cargo as efficiently as fuel in bladder sleds. 
Shoop, John Hills, and Julia Uberuaga. 2014. ERDC/CRREL TR-14-25. Maintenance and Drainage Guidance for the Scott Base Transition, Antarctica, http:/lacwc.sdp.sirsi.net/client/search/asset/1036762

The snow roads at McMurdo Station, Antarctica, are the primary transportation corridors for moving personnel and material to and from the airfields servicing intra- and intercontinental air traffic. The majority of the road system is made of snow overlying a snow and ice subsurface. However, at the Scott Base Transition (SBT), the aggregate road leading from Scott Base transitions from the land mass of Ross Island on to the ice shelf and becomes a full depth snow road. Because of the transition between materials, the topography of the area, and extensive use during the austral summer, the SBT is prone to problems unique to that portion of the McMurdo road system and requires specific maintenance activities to remain passable during periods of higher temperatures. The SBT area is divided into two subsections: the Land Transition, a soil- or aggregate-surfaced road underlain by permafrost, and the Ice Transition, a snow-surfaced road underlain by snow and ice. The two sections of the SBT need entirely different Schematic of the Antarctic French Drain construction and maintenance techniques to maintain road surface conditions that will support vehicle traffic. This document provides a baseline guide for construction, maintenance, and repairs of the two distinctly different SBT segments.

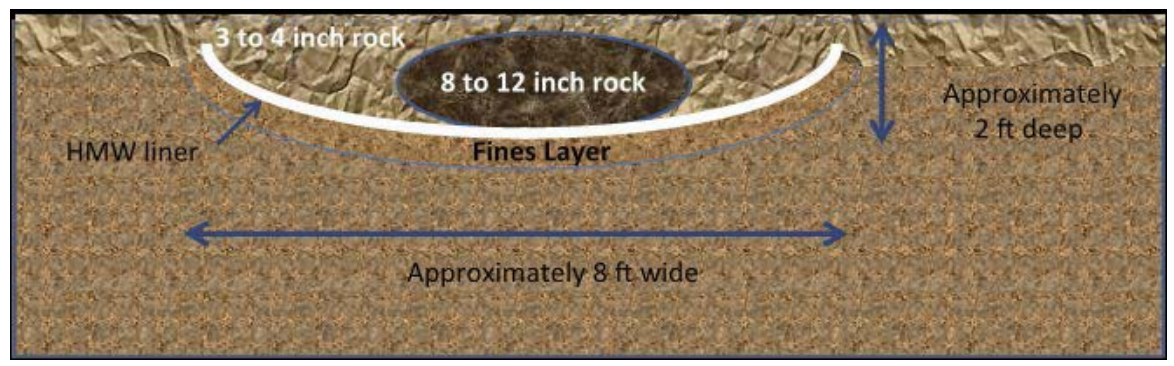

Rosa Affleck, Meredith Carr, and Brendan West. 2014. ERDC/CRREL TR-14-26. Flow Control and Design Assessment for Drainage System at McMurdo Station, Antarctica, http:/lacwc.sdp.sirsi.net/client/search/asset/1040660

Runoff at McMurdo Station is driven primarily by the melting of snow and glacier ice. Snowmelt runoff passes through McMurdo via a system of drainage ditches, gullies, and culverts. Ultimately, the snowmelt runoff discharges into Winter Quarters Bay and McMurdo Sound through several discharge points. Although the most extreme runoff during heavy flow has not been measured, it has been observed here that the runoff mobilizes sediment, erodes the drainage channels and embankments, and overflows onto roads. The objectives of this study were to manage flow; to minimize erosion; and to improve the drainage system by modeling high flows, designing control measures, and evaluating existing culvert and snow dump locations at McMurdo Station.

Flow modeling and structural analyses were conducted to determine design parameters for control measures, including rock and wooden weirs; to evaluate various design alternatives against erosion control metrics; to evaluate culvert conditions; and to investigate an alternative flow path and sediment ponds. A qualitative review of culvert conditions and snow dump locations was also performed. This report identifies specific mitigation recommendations using these control measures, which will help prevent future overflow and deterioration of the McMurdo drainage system.

Gully erosion on a slope at McMurdo, summer 2008-2009

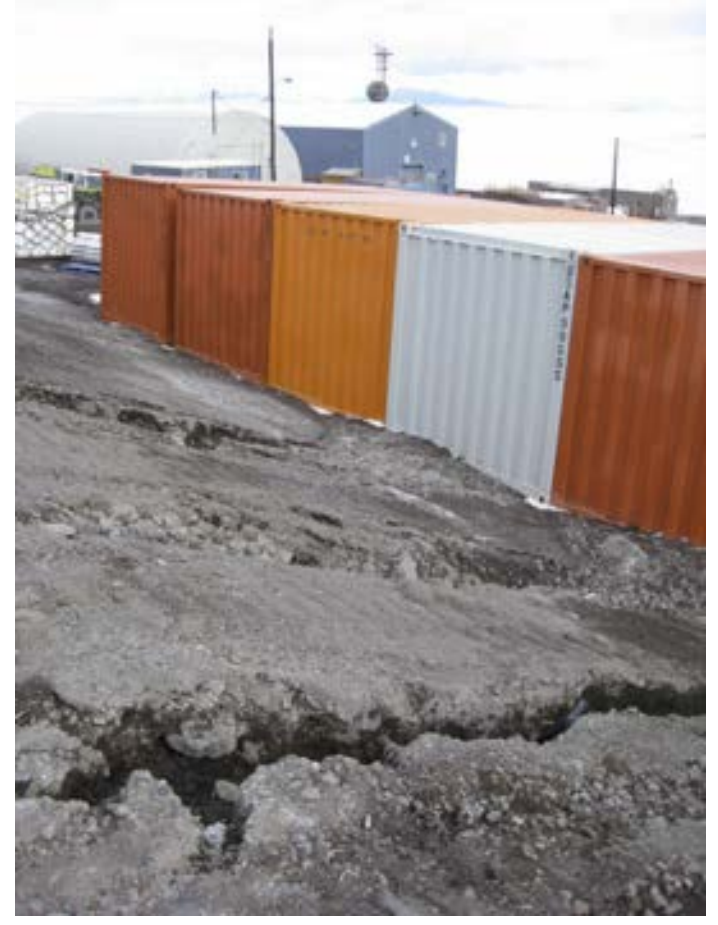


Steven F. Daly, Robert Haehnel, and Christopher Hiemstra. 2015. ERDC/CRREL TR-15-2. Vertical Temperature Simulation of Pegasus Runway, McMurdo Station, Antarctica,

http:/lacwc.sdp.sirsi.net/client/search/asset/1041462

Pegasus Runway, located $13 \mathrm{~km}$ south of McMurdo Station, Antarctica, on the McMurdo Ice Shelf (MIS), is constructed out of snow and ice. It is susceptible to weakening and damage caused by melting and to reduction in the strength caused by warm weather and sunlight. This report describes the development of the Pegasus Runway temperature model. It begins by quantitatively describing the physical properties of the Pegasus Runway snow and ice and the physical properties of the MIS directly beneath the runway. The temperature model is based on a one-dimensional heat conduction model that includes the penetration and absorption of solar radiation beneath the surface. The report describes the methods for estimating the sensible heat, latent heat, shortwave radiation, and long-wave radiation surface heat fluxes that drive the model and presents estimates of the constant-temperature lower-boundary condition for the model. A novel approach for estimating the initial vertical temperature profile is used. This work simulated the Pegasus Runway temperatures for three austral summer sea-sons (2011-12, 2012-13, and 2013-14). The model simulation shows good results when compared to in situ observations of the runway temperatures.
View of the trench used for installing temperature sensors in the runway

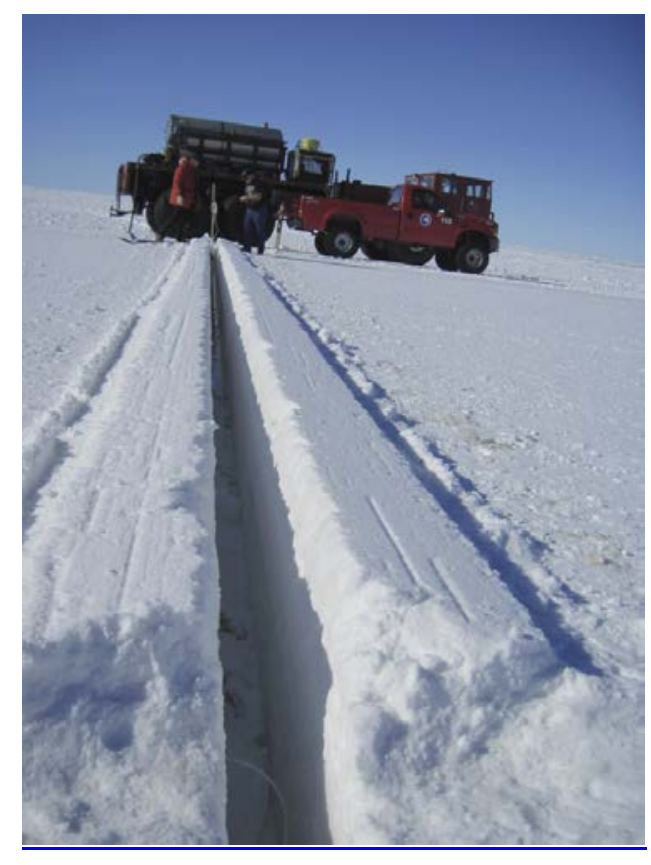

Lynette Barna, Zoe Courville, John Rand, et al. 2015. ERDC/CRREL TR-15-9. Remediation of Old South Pole Station: Phase I: Ground-Penetrating-Radar Surveys, http://acwc.sdp.sirsi.net/client/en_U.S./search/asset/1044471 Old South Pole Station was built between 1956 and 1957 to support the International Geophysical Year. At the time, the buildings composing the main station complex were built on the snow surface, but the increasing depth of snow overcame the structures. In an effort to displace the deepening snow and resulting snow loads, wooden structures called "top hats" were built on top of the roofs of the original buildings. These buried buildings and additional top hat structures created dangerous subsurface voids and then further acted to weaken overlying snow layers.

This work therefore conducted ground-penetrating-radar (GPR) surveys at the Old South Pole Station site to identify buried

Amundsen-Scott South Pole Station entrance in 1970, completely buried by accumulated and drifted snow

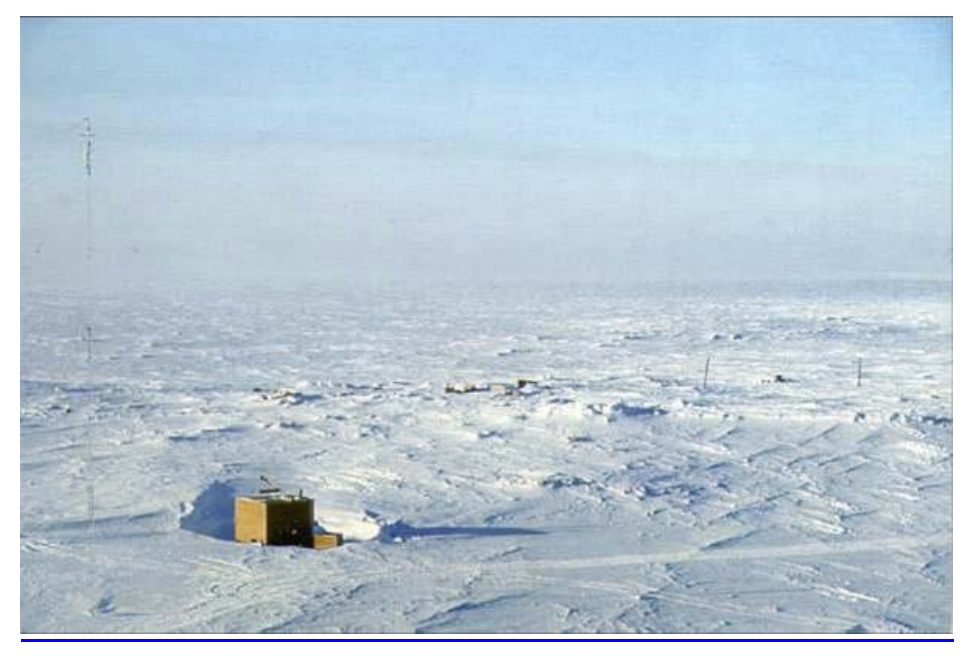
buildings and potential hazards. The GPR survey included techniques used in crevasse detection to identify the locations and dimensions of the buildings. GPR located several top hat roofs as shallow as $14 \mathrm{ft}$ below the snow grade with the roofs of the station buildings $30 \mathrm{ft}$ below the surface at the time of the survey. As a result of this study, GPR located nine buildings within the main complex, which were then imploded using blasting. This report describes the methods used to identify the buried buildings and reviews the blasting operations. 
Lynette Barna, James Lever, and Allan Delaney. 2015. ERDC/CRREL TR-15-10. Remediation of Old South Pole Station Using Autonomous Data Collection and Remote Assessment of Ground-

Penetrating Radar, http:/lacwc.sdp.sirsi.net/client/search/asset/1044472

This report describes a GPR survey assessing the effectiveness of blasting subsurface hazards at the original South Pole Station. Hidden under layers of accumulated snow, false attic structures ("top hats") were built on top of the original buildings to displace the increasing snow depth. By causing an alteration in the snow structure through enhanced metamorphism, the presence of these structures and heat from the buildings reduced the bearing capacity of the overlying snow to support surface-based heavy vehicle.

Blasting was an effective method to mitigate the subsurface safety risks posed to personnel and equipment operating in the area. The resulting blast crater naturally filled with drift snow. An autonomous polar rover was deployed and successfully conducted a post-blast GPR survey operating at ambient temperatures of $-22^{\circ} \mathrm{F}$ or lower. Expert review of the GPR data confirmed that the targeted structures within the crater were effectively demolished. Data collected by the rover revealed two sites beyond the crater perimeter, yet within the survey area, that posed a risk to heavy vehicles. A mitigation effort included these two areas. Data collection with an autonomous rover and offsite expert data review proved to be effective tools for use at South Pole.

In Area 2, excavation exposed the supporting members (believed to be the ceiling-floor between the second and third floor levels) of Building A15, an aluminum-framed square structure.

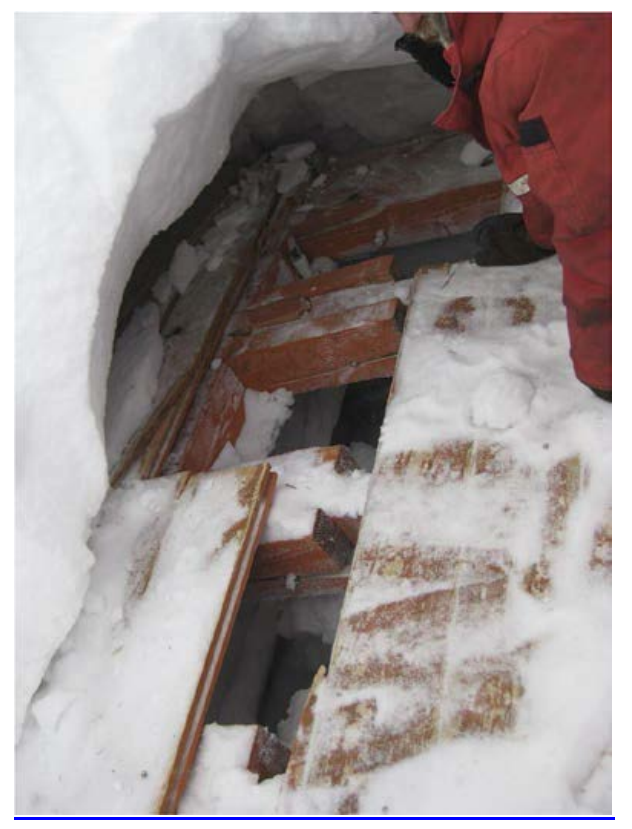

Kevin Bjella. 2015. ERDC/CRREL TR-15-13. Geotechnical Study, Next Generation Ionosonde (NEXION) Installation, Thule Air Base, Greenland, http:/lacwc.sdp.sirsi.net/client/search/asset/1045949

This report presents the results of a geotechnical and structural design for the transmitter antenna of the NEXION at Thule Air Base, Greenland, for the Space and Missile Systems Center, Remote Sensing Space Environmental Branch, and Air Force Weather. NEXION is a commercial-off-the-shelf ionospheric sounder used to measure the electron density of ionospheric plasma. The design required special considerations for installation, construction, and shipment due to the ice-rich permafrost soil conditions at Thule Air Base's remote and logistically difficult location. In particular, anchored tension ground connections could not withstand viscoelastic creep of ground ice under extreme wind-loading events. In addition, predicted future climate change required additional considerations to protect the thermal regime of the thaw-unstable sediments.

Recommendations include excavation into permafrost soils, non-frost-susceptible structural replacement fill, and extruded polystyrene board-type insulation to facilitate maintaining and improving the subsurface thermal regime and to provide favorable foundation performance for the NEXION tower system. Furthermore, given the remote site location and limited availability of on-site concreting capabilities, foundations require pre-casting and shipping via ocean transport vessel to Greenland. As such, an alternative foundation detail was designed, including anchor rods, to mitigate the potential for irreparable damage that may occur during shipping and transporting. 
Steven F. Daly. 2015. ERDC/CRREL TR-15-16. Review of the Probable Maximum Flood (PMF)

Snowmelt Analysis for Success Dam,

http://acwc.sdp.sirsi.net/client/search/asset/1047629

This report reviews the initial snowpack distribution assumed to be in place and available for melt in the PMF analysis of Success Dam conducted by the Corps of Engineers. This project reviewed two aspects of the initial snow distribution: the snow-covered area (SCA) distribution and the snow water equivalent (SWE) distribution. Satellite imagery were analyzed to determine the daily SCA of the Success Dam watershed from 2000 to 2014. This analysis was based on time-domain filtering of NASA's daily snow product. The SCA of the Success Dam watershed is highly dynamic with large day-today variations. The maximum 95th percentile SCA for each elevation band was selected to describe the initial snow cover in

Success Dam, CA

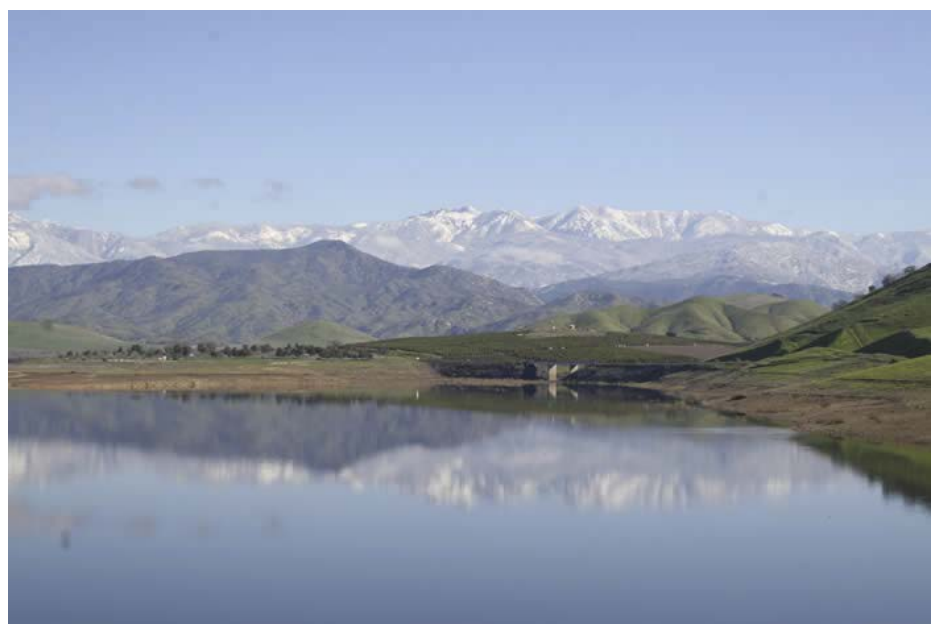
place at the start of the PMF analysis. Next the initial SWE distribution was reviewed. Above $5000 \mathrm{ft}$, the initial SWE distribution was greater than the snowmelt that occurred during the PMF and was therefore heat transfer limited. In this region, the snowmelt runoff during the PMF was insensitive to the amount of SWE. Below $5000 \mathrm{ft}$, the snowmelt was limited by the initial SWE. Runoff from this region is sensitive to the amount of initial SWE.

\section{Rosa T. Affleck, Charles Smith, Andrew Bernier, et al. 2015. ERDC/CRREL TR-15-17. Structural Condition Assessment of Reinforced Base Course Pavement, http:/lacwc.sdp.sirsi.net/client/search/asset/1047549}

In 2011, the New Hampshire Department of Transportation (NHDOT) reconstructed 2 miles of Pickering Road in Rochester. This included building three distinct reinforcement conditions: a geogrid reinforcement within the granular base-course layer and no geotextile separator, a geotextile separator between the subgrade soil and the subbase course, and a geogrid reinforcement within the granular base-course layer with a geotextile separator between the subgrade and the subbase layer.

CRREL conducted a series of falling weight deflectometer (FWD) tests to monitor changes in layer moduli as the seasons changed. FWD tests occurred several times throughout the year on selected locations along the reinforced and non-reinforced (southern portion) pavement. Based on the seasonal back-calculated moduli for 2014 and 2015 values, the reinforced geogrid granular base-course layer provided higher moduli than the nonreinforced sections, and it appears that the aggregate layer thickness can be reduced to $33-42 \%$ if the base course is reinforced with a geogrid mesh. This higher stiffness should allow the pavement to withstand many more traffic repetitions before fatigue cracking develops; and the geogrid should minimize the influence on thermal cracking.
Cored asphalt concrete

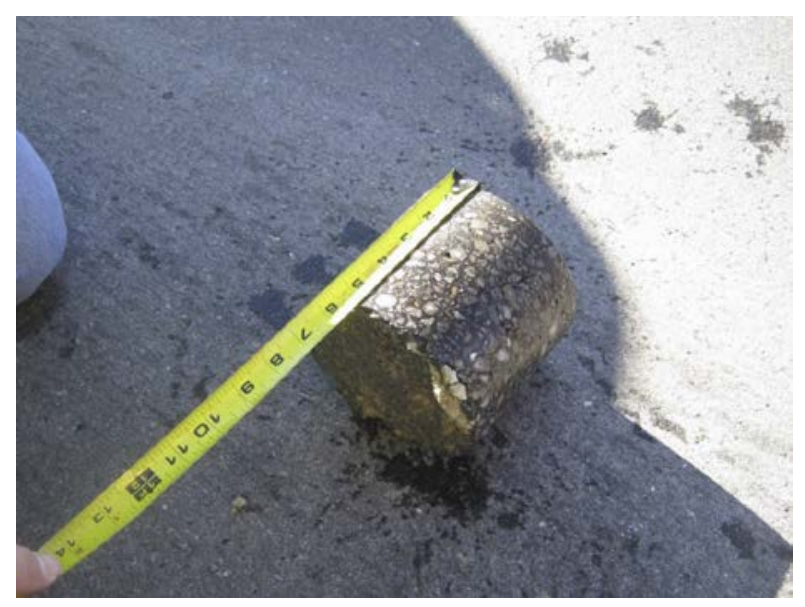


Robyn A. Barbato, Karen L. Foley, and Charles M. Reynolds. 2015. ERDC/CRREL TR-15-6. Soil Temperature and Moisture Effects on Soil Respiration and Microbial Community Abundance, http:/lacwc.sdp.sirsi.net/client/search/asset/1042506

Soil biological processes are influenced by dynamic soil descriptors, such as water potential and temperature, and more stable factors, including organic matter content and particle size distribution. To better understand how soil temperature and soil water potential influence microbial activity, soil respiration was measured in laboratory incubations of four different soils. Though three of the soils had the same soil texture, they varied considerably by $\mathrm{pH}$ and soil nutrient concentrations. The soils were found to vary in how their native soil microbes responded to a range of soil water potential and temperature values, with soil activity being highest at approximately $30^{\circ} \mathrm{C}$ and $-33 \mathrm{kPa}$. Further, the peak respiration rate for the soil with the highest measured organic matter content was $329.8 \mathrm{mg} \mathrm{C}-\mathrm{CO} 2 \mathrm{~m}-2$ day-1 and the rate for the soil with the lowest measured organic matter content was $14.7 \mathrm{mg} \mathrm{C}-\mathrm{CO} 2 \mathrm{~m}-2$ day -1 . Those soils with elevated organic matter content also contained the highest abundance of bacteria and archaea. Across all soils, if the moisture content was optimal but the temperature was around $5{ }^{\circ} \mathrm{C}$, the respiration rate was reduced. Therefore, microbial activity may depend more on temperature though moisture clearly had an effect on activity.

Conceptual model of a soil pore, emphasizing soil microorganisms' role in heterotrophic respiration

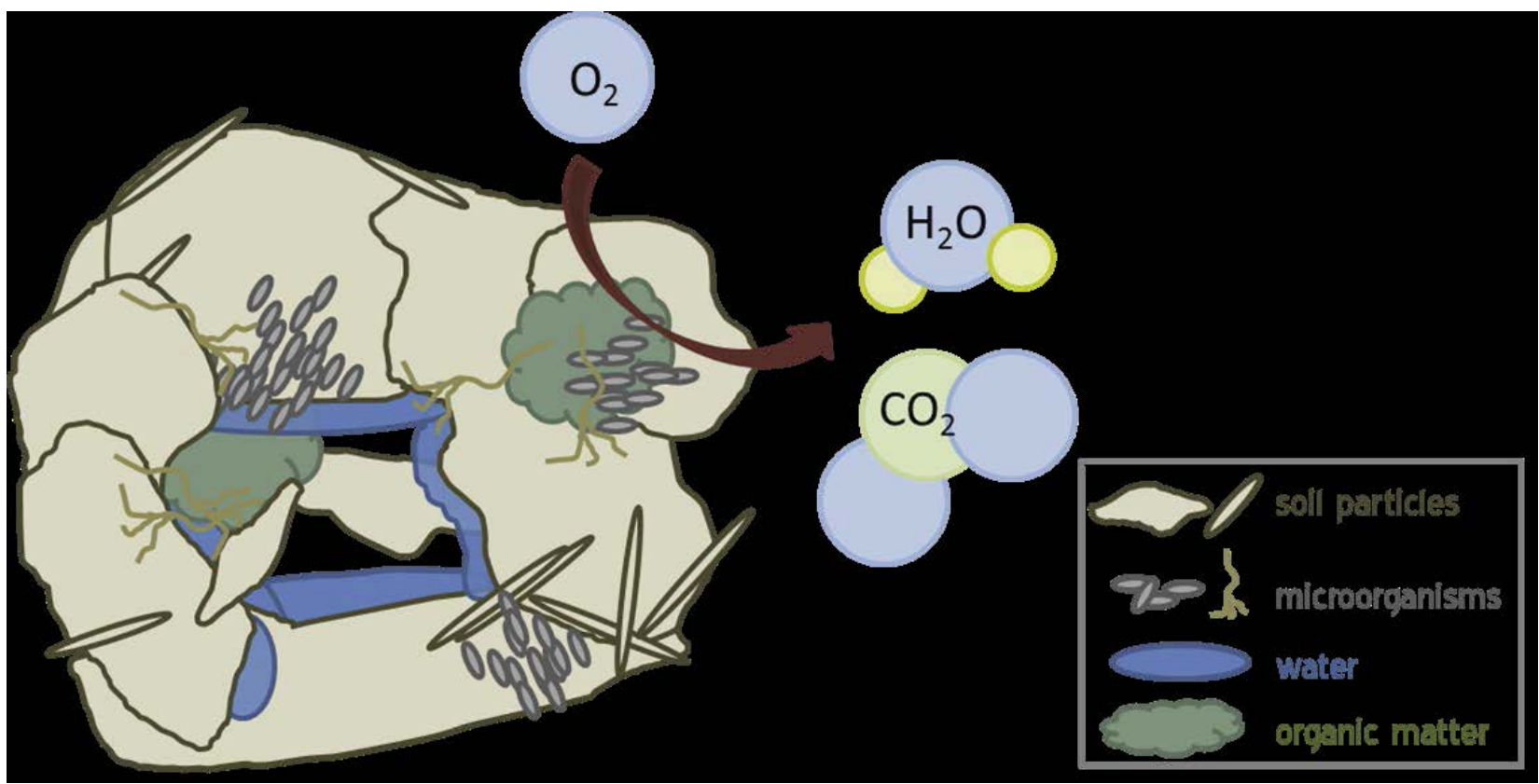




\section{Sustainable Contingency Basing}

This focus area relates to identification of the Army's required capabilities for full spectrum contingency operations. To meet the objectives of this focus area, a multi-disciplined approach is necessary to develop solutions that ensure sustainability and efficiency while eliminating redundancy in a contingency environment.

\section{John L. Vavrin and Ian McNamara. ERDC/CERL TR-14-22. Design Enhancements to Facilitate a Sustainable and Energy Efficient Dining Facility (DFAC) in a Contingency Environment, http:/lacwc.sdp.sirsi.net/client/en US/search/asset/1036662}

DFACs in a contingency environment consume large amounts of energy and resources, and generate large amounts of food and solid waste daily. Almost all CB DFACs provide individual paper and plastic ware, which is costly in terms of purchase, transportation, and disposal. This work analyzed the effects of replacing paper and plastic ware with reusable materials, and of adding industrial dishwashers to reduce the logistical burden of using paper and plastic ware. Additional enhancements analyzed were: (1) greywater heat recovery units, (2) solar water heaters, and (3) anaerobic biodigesters. Implementing dishwashing facilities on contingency DFACs was found to be economically viable. Greywater heat recovery was recommended as a standard addition to dishwashing facilities at contingency DFACs. Solar water heating was recommended only at enduring contingency base camps. Anaerobic biodigesters were recommended for base-wide use.

Greywater heat recovery unit

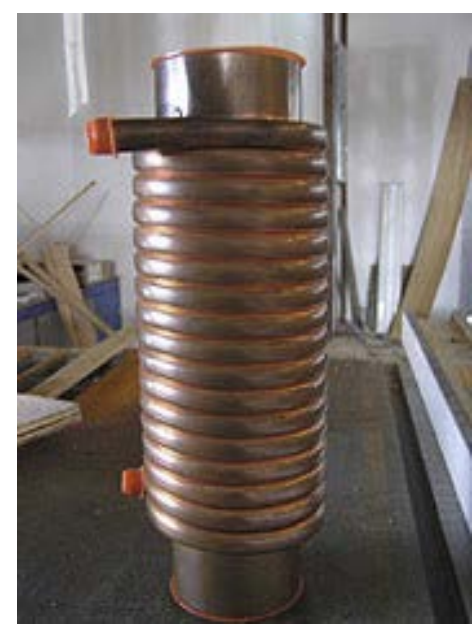

Charles T. Decker, Andrew C. Johannes, Jed B. Alvey, et al. Draft ERDC/CERL TR. Opportunities for Waste Heat Recovery at Contingency Bases.

The energy requirements of CBs involved in U.S. military operations on every continent are met almost exclusively with the use of diesel generators, which are relatively inefficient both in terms of fuel consumption and the large amounts of waste energy generated during their operation. Tactical generators are currently loaded only to 30 to $40 \%$ capacity, due in large part to the sizing of generators to cover large electrical loads like electric heating of space and water. This work was undertaken to estimate the amount usable of available waste heat that could be captured and reused to heat buildings and provide hot water while reducing generator fuel demand. It was found that the use of otherwise wasted thermal byproduct of the diesel generator for space and water heating allows loads to be consolidated so the numbers and sizes of generators can be dramatically reduced. The use cogeneration can lead to total fuel savings of nearly $20 \%$ Waste heat from five $60 \mathrm{~kW}$ generators can supply water heating for an entire 300 personnel contingency base, and in austere conditions, up to $1.75 \mathrm{gpm}$ per implementation.

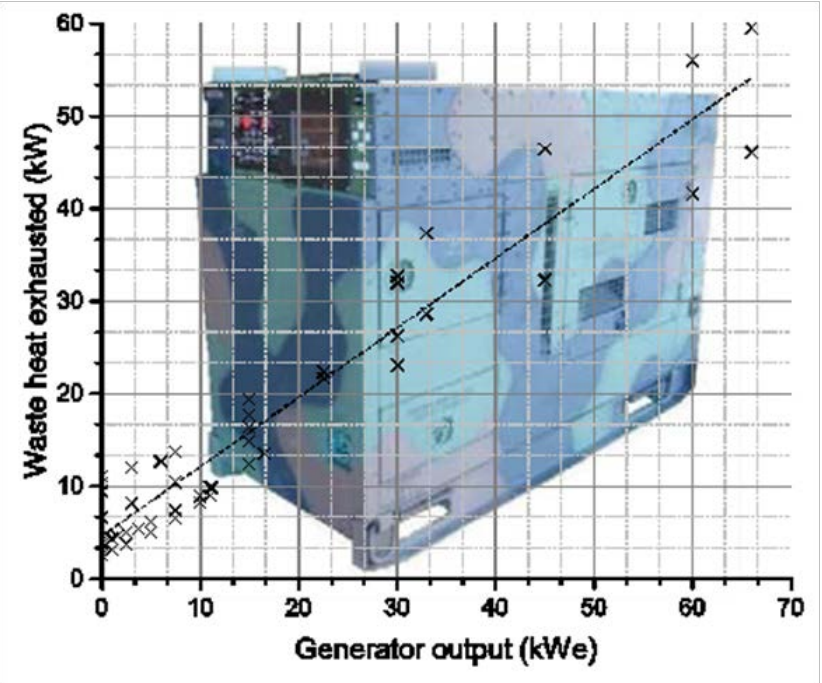


John L. Vavrin and William J. Stein. ERDC/CERL TR-15-27. Mold Remediation and Recommendations to Resolve Other Major Issues in Concrete B-Huts at Bagram Airfield, Afghanistan (Distribution C).

The wooden barracks hut, or the "B-hut" is one of the easiest and quickest structures the military can build for administrative, operations, and living facilities. However, wooden B-huts offer no protection against small arms or indirect fire, are energy inefficient, support only eight Service Members, and are not easily relocatable. To improve force protection, concrete B-huts were designed and built at Bagram Airfield, Afghanistan from 2011 to 2013. However, their design created an environment characterized by mold growth, poor indoor air quality, water infiltration, and uncomfortable living temperatures in extreme weather conditions. These conditions were caused by lack of tempered outdoor air, no insulation, inadequate heating and cooling systems, and water infiltration. This work developed a comprehensive solution to address mold issues and other deficiencies in these concrete B-huts, including: cleaning and drying the interior with a commercial biocide, sealing exterior surfaces and floors,

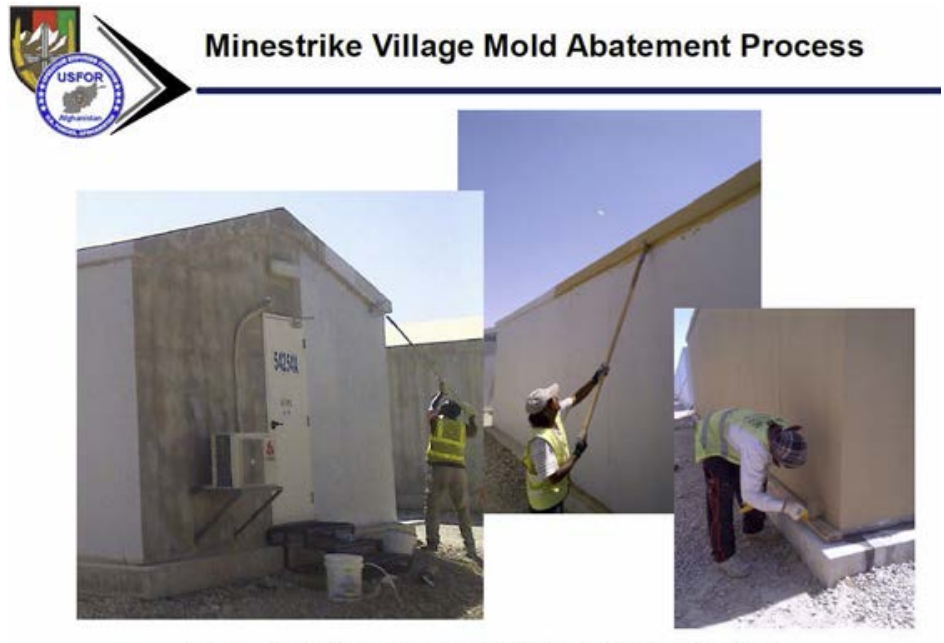

Exterior Sealant and Ceramic Paint installing heat recovery ventilators, painting interior surfaces with antimicrobial paint, and installing exterior insulation and radiant heaters. All recommendations were implemented except interior painting, radiant heaters, and insulation. At the time of this publication, with the exception of 1 month, monthly inspections reported no mold in the facilities.

\section{Victor F. Medina, Scott Waisner, Steven Cosper, et al. ERDC TR-14-3. Anaerobic Digestion Assessment for Contingency Base Waste, http:/lacwc.sdp.sirsi.net/client/search/asset/1034690} A study was conducted to evaluate anaerobic digestion as a means of treating organic waste from CBs and generating energy from the process through biogas. The project focused on laboratory studies to evaluate the treatment of applicable wastes and determine gas production. The study found that food waste is very effectively treated, and generates relatively large gas volumes. Methane concentrations in the gas range from 60 to $70 \%$. Studies with latrine wastes also had high gas production, and inhibition by toilet chemicals was minimal. A pilot study was conducted at the Contingency Base Integration and Technology Evaluation Center (CBITEC) at Fort Leonard Wood. Calculations suggest that the generated gas could offset energy use by 15 to $30 \%$, depending on the size of the $\mathrm{CB}$, and fuel cost savings (fully burdened and incorporating estimates for force protection) were estimated to be as high as $\$ 500,000$ per month. Some issues were identified regarding reaction instabilities that could cause the reactors to fail. Some solutions were suggested to address these issues; one in particular uses a mix of wastes with food that should improve stability and increase the utility of the process.
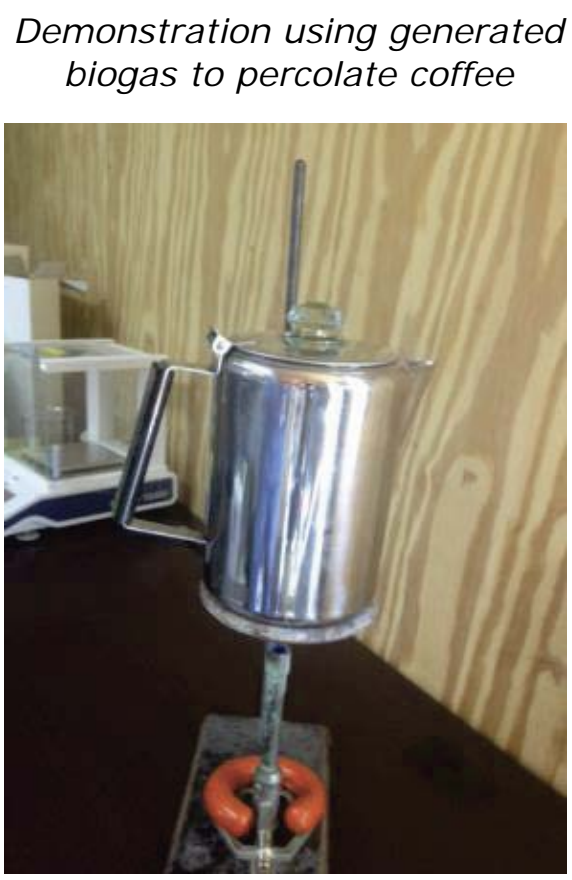
Anderson, H. Garth, Annette L. Stumpf, Rodriguez, Giselle, et al. 2014. ERDC/CERL TR-14-20. Sustainability Criteria for Contingency Bases, http:/lacwc.sdp.sirsi.net/client/en_US/search/asset/1036881

Contingency base supply lines represent an ongoing vulnerability in U.S. contingency operations. Base camp materiel, energy, and water requirements must be met using risky ground convoys or, alternately, expensive air transport. The problem is aggravated by a lack of base camp planning and design guidelines, which negatively affect operational efficiency and logistical sustainability. U.S. design and construction communities have developed criteria to improve the sustainability of standard facilities and infrastructure, such as Leadership in Energy and Environmental Design (LEED) and the Sustainable Sites I nitiative. The direct applicability of such criteria to military contingency operations is limited, however, be-cause of unique military requirements and the scarcity of U.S. standard construction materials and equipment.

This study examined various design and construction sustainability programs and identified concepts, guidelines, and practices relevant to military contingency infrastructure construction. The report collects and adapts design and construction criteria that can feasibly be applied by engineers, planners, and base operators to establish and sustain contingency bases. Application of these guidelines could significantly decrease the logistical footprint of the contingency base by reducing the consumption of construction materials, energy, and water.

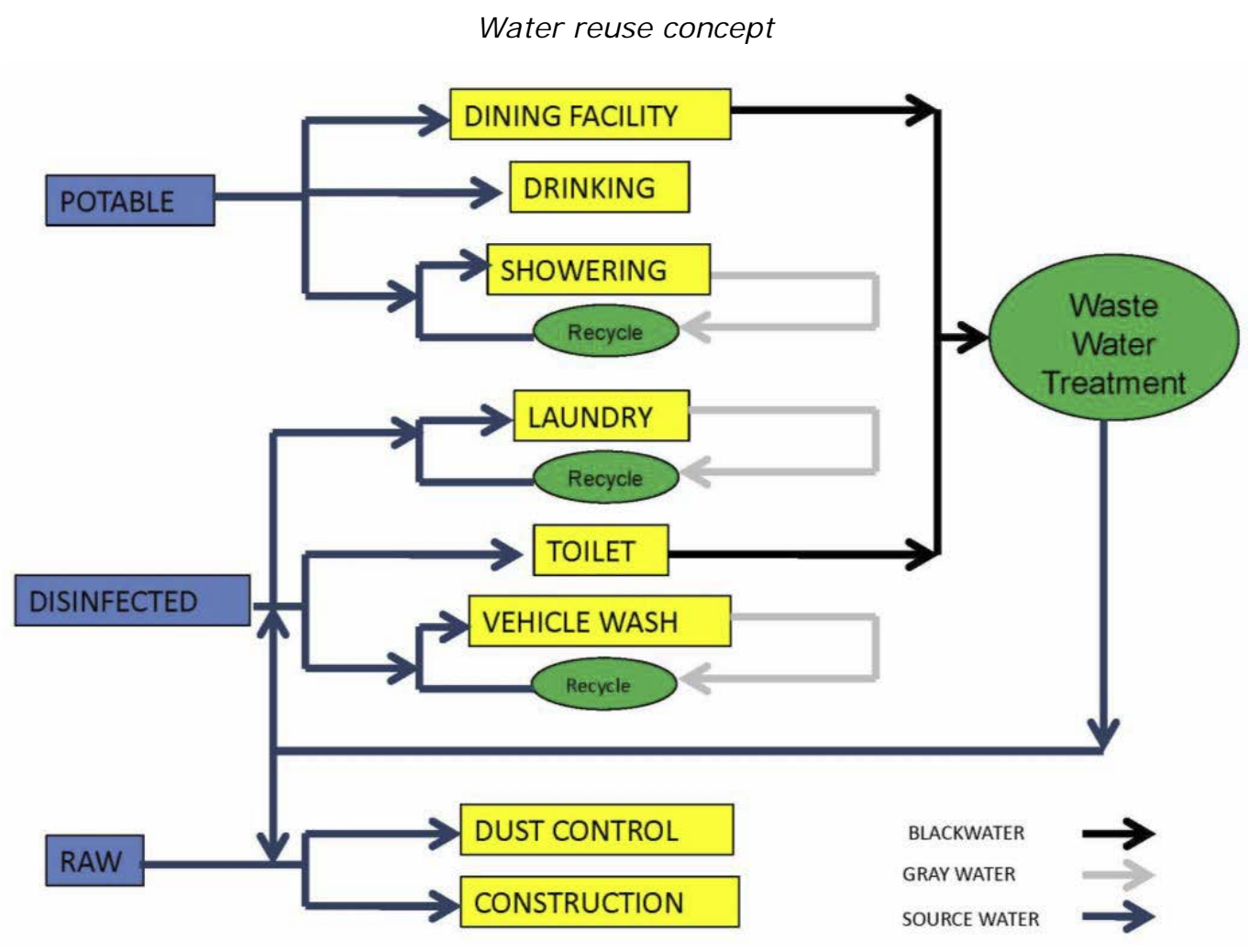




\section{Sustainable Natural Infrastructure}

The U.S. Army Corps of Engineers strives to protect, sustain, and improve the natural and manmade environment of our Nation, and is committed to compliance with applicable environmental and energy statutes, regulations, and Executive Orders. The Corps of Engineers is committed to ensuring that sustainability is not only a natural part of all our decision processes, but should also part of our organizational culture. The Corps, which is a steward for some of the Nation's most valuable natural resources, strives to ensure sustainable solutions that address short and long-term environmental, social, and economic considerations.

The purpose of this focus area is to engage stakeholders through forums, white papers, publications, and other means regarding DoD-related concerns with natural resources, both in terms of managing DoD assets and natural resources as they relate to international and national security and stability.

David Delaney, Patrick Guertin, Michael White, et al. 2016. Draft CASI TN.

Assessment of Small Arms Munitions Impacts on Natural Infrastructure in Sensitive Downrange Areas on Military Installations, http://acwc.sdp.sirsi.net/client/en US/search/asset/1048789

Large areas of high-quality terrestrial natural infrastructure exist downrange of small-arms training ranges on DoD installations. Live-fire training has caused concern to regulatory entities due to the potential impacts on natural resources, and to safety concerns expressed by adjoining land owners. This paper investigated whether there are reliable documented methods to quantify the number of bullets that escape the cantonment berm and end up down range via queries among Natural Resource peers and a technology review to document existing methods that address bullet fate on ranges. Responses to the inquiries indicate that Natural Resource personnel on military facilities or other state or federal agencies do not have adequate tools or guidance to address the potential issue of smalls arms munition impacts within sensitive downrange areas. It was recommended that military installations further examine acoustical techniques for quantifying bullet overshot and ricochets into sensitive wildlife areas. Acoustical techniques offer a viable method for quantifying bullet intrusions into downrange areas. However, a more comprehensive testing procedure must be tested to gauge the effectiveness of this technique at bermed and unbermed ranges under different field conditions.

\section{Rosemary Keane, Hannah Pitstick, Patrick J. Guertin, et al. ERDC/CERL SR-14-8. Forest Microclimate Characteristics: Annotated Bibliography, http:/lacwc.sdp.sirsi.net/client/en_U.S./search/asset/1036580}

The U.S. Army owns many acres of forested training lands. Management of these forest lands can impact the Army's ability to meet training goals as these lands have implications to noise mitigation and TES populations. To support the need to manage these forested areas, the ERDC-CERL Environmental Processes Branch conducts ongoing studies of forest lands, including the possible implications of climate change on forests. An important subtopic of that study is the microclimate a forest creates under and within its canopy; a forest microclimate can affect a wide variety of factors within the forest including how sound travels, how vegetation regenerates, and how fauna interacts. This report supports that
Microclimates vary within forests and impact forest environmental components

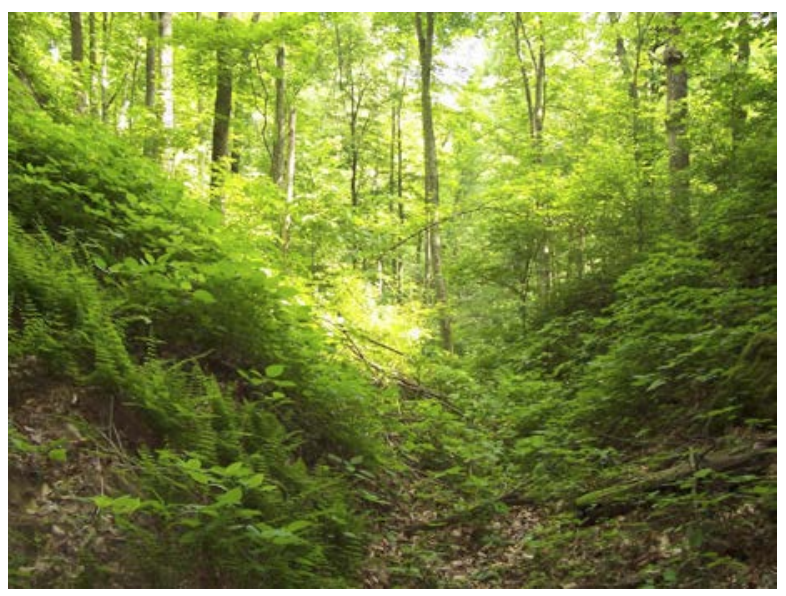


important subtopic by creating an annotated bibliography of works related to how microclimates varied within forests and how they impacted environmental components within the forest. The resulting information will provide insight on how to design future work to capture relevant data and how to interpret those results.

Natalie Myers, Daniel Koch, Andrew Fulton, et al. ERDC/CERL TR-14-13. Using Simple Environmental Variables to Estimate Biomass Disturbance, http:/lacwc.sdp.sirsi.net/client/en US/search/asset/1035942

Proper management of military training lands is critical to ensure availability of training lands, and thereby ensure mission readiness. However, installation land management often supports a broader mission than simply maintaining the land in a condition suitable for training, including activities as agriculture and grazing outleases, and protection of habitat to conserve federally listed TES. Proactive land management practices that support such potentially conflicting land uses must take a systematic approach that considers, coordinates, and integrates complex land impacts. Development of the Optimal Allocation of Land for Training and Non-Training Uses (OPAL) Program was undertaken to meet this need. This phase of work developed algorithms for estimating cumulative land disturbance on military training lands through above- and below-ground biomass responses. Algorithms developed here specifically focused on four aspects of the relation between above- and below-ground biomass and natural resource disturbance: (1) use of above- and below-ground biomass to quantify disturbance, (2) forecasting soil temperature and moisture as a consequence of weather, (3) distribution of training and its impacts on biomass, and (4) impacts of burning/haying on land management.

Biomass lifecycle

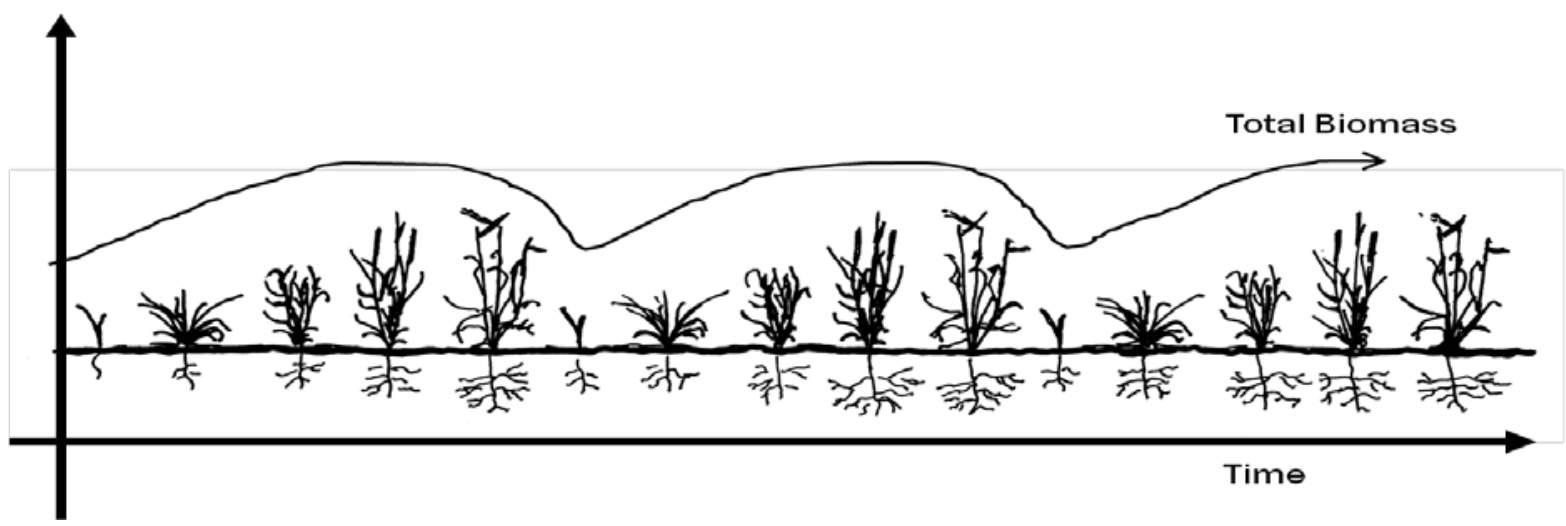

Jinelle H. Sperry, Wade Wall, and Todd Swannack. ERDC SR-15-3. Evaluation of Suitable Population and Habitat Suitability Models for Endangered Avian Species Populations on Fort Hood, TX (Distribution D).

Fort Hood supports significant populations of two federally listed endangered species, the Golden-cheeked warbler and Black-capped vireo. Fort Hood implements intensive inventory and monitoring programs for these species to track population status and trends and mitigate population limiting factors. The impacts of management and military activities on these species and the associated continued viability of these populations have been previously evaluated using a variety of modeling approaches. This work: (1) evaluated the scope of endangered species monitoring, management, and assessment necessary to support installation requirements, (2) identified and evaluated models that best support installation requirements, and (3) provided suggestions to improve those models.

Four candidate models (two for each species) were identified. For Golden-cheeked warblers (below, left), two models use well recognized approaches and predict warbler occupancy/abundance. Both would be good candidates for management planning and a detailed model comparison, using a common dataset, would allow a more detailed evaluation of each 
model's accuracy. However, the two models identified for Black-capped vireos (rightmost photo) suffered shortcomings that may limit their usefulness for species management. Methods were recommended to improve the models to increase their utility.
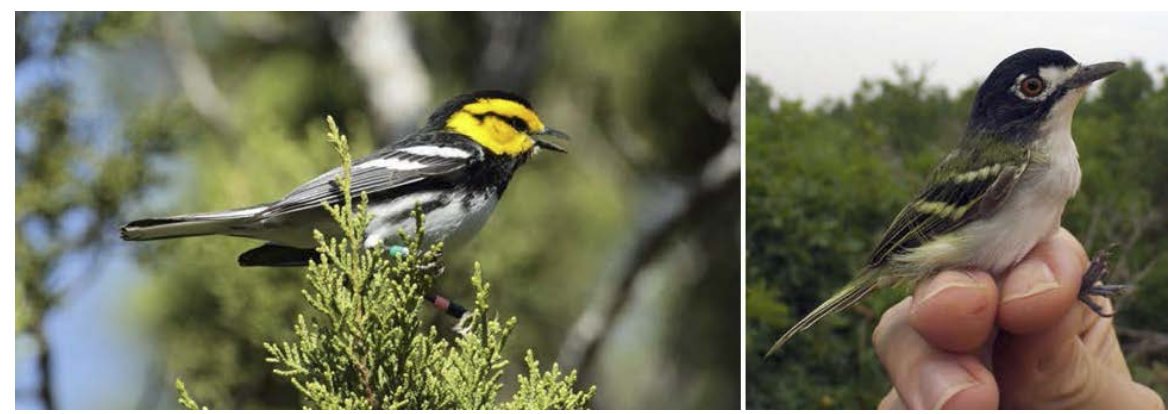

Scott A. Tweddale, Patrick J. Guertin, and George Z. Gertner. ERDC/CERL TR-14-18. Remote Sensing Protocols for Parameterizing and Individual Tree-Based Forest Growth and Yield Model http://acwc.sdp.sirsi.net/client/en U.S./search/asset/1036582

Potential impacts of climate change to southeastern U.S. pine ecosystems are of particular concern to DoD due to the large number of military installations within this ecoregion and multiple natural resource management concerns related to these forest types, including their importance for multiple TES. The U.S. Forest Service-developed Forest Vegetation Simulator - Southern Variant (FVS-Sn) forest growth model can project growth in southeastern U.S. pine ecosystems, and it has been modified to incorporate the effects of climate change. Stand inventories are typically used to parameterize FVS-sn growth models, but field-based inventories are cost-prohibitive to collect at landscape scales. Therefore, remote sensing protocols were developed to parameterize the FVS-sn model. More specifically, a tree-finding model was developed to estimate the location and height of individual stems using Light Detection and Ranging (LiDAR) data. Estimated stem locations from the treefinding model matched 74 and $98 \%$ of field-mapped longleaf and loblolly stems, respectively. Using estimates of stem height, height to live crown, localized stem density, and crown area for a total of 160 matched stems as predictor variables in regression analysis explained 68 and $71 \%$ of the variation in field-measured diameter at breast height (dbh) for longleaf and loblolly stems, respectively. Using this protocol, a landscape-wide map of stem locations attributed with species, height, dbh, and crown length could then be used to parameterize the FVS-sn model.

Daniel Koch, Scott Tweddale, James Westervelt, et al. ERDC/CERL SR-14-7. Opal Land Condition Model, http://acwc.sdp.sirsi.net/client/en US/search/asset/1035943

Proper management of military training lands is critical to ensure availability of training lands to ensure mission readiness. However, installation land management practices often support a broader mission than simply maintaining the land in a condition suitable for training. The U.S. Endangered Species Act requires the Army to conserve federally listed TES on installation lands. The Army often makes proactive management efforts to eliminate potential conflicts between Threatened, Endangered, Proposed, and Candidate (TEPC) species and military mission and management efforts. Installations' I ntegrated Natural Resources Management Plans (INRMPs) include practices that benefit the conservation of species of concern, e.g., by incorporating plans to enhance or preserve critical habitat through such management practices as controlled burns.

This report provides user and programmer information supporting the OPAL model, which was designed for use by trainers, ITAM coordinators, and land rehabilitation offices. The model provides an environment for testing how different combinations of training schedules, haying and burning schedules, and weather affects the quality of the lands vegetation, which provides training realism and erosion protection. 
Heidi Howard, Donald Althoff, Erich Sprague, et al. ERDC/CERL SR-14-2. Rapid Assessment of Disturbances and Landscape Features Using a Tethered Low-Level Aerial Digital Photography System (Distribution C).

DoD is the second-largest land steward in the United States and oversees 25.7 million acres of land. With development of multiple land uses on installation lands (both cantonment as well as range areas), there is a need to monitor and assess land condition relative to site impacts. Low-altitude unmanned aerial systems have been proven useful for rapid reconnaissance in aiding situational, emergency, and disaster management. Given the proven success and positive application of these technologies, this work evaluated their use within the ITAM program for land condition assessment as well as for other functions outlined above.

\section{Donald Althoff, Heidi R. Howard, Erich Sprague, et al. ERDC/CERL SR-14-1. Low Altitude Balloon Methods for Range Training Land Assessment (RTLA) At Military Installations (Distribution C).}

$\mathrm{DoD}$ is the second-largest land steward in the United States and oversees 25.7 million acres of land. Monitoring of land condition is essential to sustainment efforts because mechanized maneuver training alters the landscape by increasing exposure of soils, accelerating soil erosion, reducing native flora and fauna, and spreading invasive species. Traditional methods for acquiring photographic data used to document disturbance, whether ground-based or remote, are labor-intensive and provide no assurance that the same exact area can be resampled with near $100 \%$ accuracy for follow-up surveys. Unlike satellite or aircraft data collection, tethered low-level aerial photography systems offer the flexibility of scheduling with relatively low processing costs, and can provide accuracy of data below $100 \times 100$ m plots. Conservation, Environmental, as well as RTLA program managers can use low-altitude photographs to inventory and monitor natural resource conditions and to manage and analyze natural resource information. This work was undertaken to document methods for using low-altitude balloon systems as a supporting means to repeatedly document and analyze changes in landscape from disturbance and to identify landscape features.

\section{James D. Westervelt and Grace M. Diaz-Estrada. Draft ERDC/CERL TR. Black-Swan Event Assessment for Fort Leonard Wood, Missouri.}

Emergency preparation typically involves evaluating disaster potential and consequences, followed by disaster preparedness. Potentials are informed by history, with the easy human belief that one must obviously prepare for the past. However, a class of disasters involve events that may not have been anticipated, but in hindsight appear to be obviously overlooked. This report attempts to identify such "black swan" events, i.e., potential disasters in the Fort Leonard Wood area that might well attract more attention in future planning exercises.

\footnotetext{
Molly K. Reif and Todd M. Swannack. ERDC/EL TR-14-6. Development of Landscape Metrics to Support Process-Driven Ecological Modeling, http:/lacwc.sdp.sirsi.net/client/search/asset/1034186 Landscape pattern is an important driver in ecosystem dynamics and can control systemlevel functions such as nutrient cycling, connectivity, biodiversity, carbon sequestration, etc. Advances in remote sensing and GIS have led to increased capability for quantifying landscape pattern, which is essential for relating spatial patterns to ecological processes.
} 
This study analyzes GIS and remote sensing data from two time periods, 2006 and 2010, over an approximately $2-\mathrm{km}^{2}$ area in coastal Southwest Florida, to develop and examine landscape metrics with the goal of obtaining a better understanding of the factors that influence landscape changes observed as a result of the 2004 and 2005 hurricanes. Results are summarized by the change detection statistics and the landscape metrics, illustrating how quantitative measures can be applied to land cover data and assess both general land cover characteristics and underlying structure, aggregation, and shape characteristics. The landscape metrics analyses provided important indicators regarding the nature of the landscape changes and, thus, revealed important clues about the underlying ecological processes shaping them. This study represents an important first step in understanding how landscape metrics can be developed and in examining their potential use for linking spatial process to ecological pattern. More importantly, it also sets the stage for future research that will relate these findings to long-term ecological modeling and apply them to Engineering With $\mathrm{Na}$ ture projects and Regional Sediment Management initiatives.

History of the North Captiva Island breach, a result of Hurricane Charley in 2004:

(a) site in 2004, (b) small channel in 2006, and (c) repaired in 2010
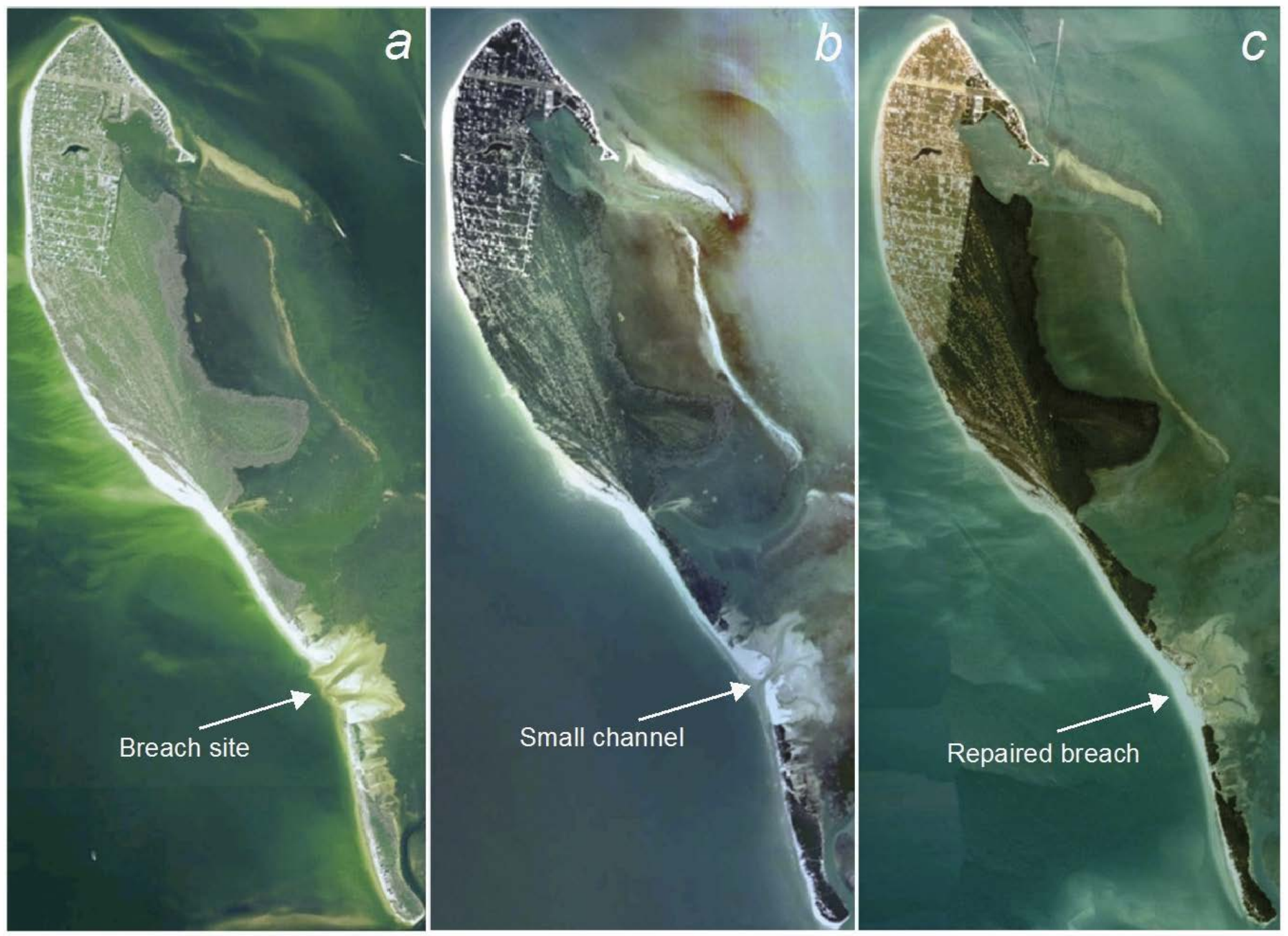
Todd Swannack, James Westervelt, Jeff Hensley, et al. ERDC TR-14-11. Ecological Modeling System: Conceptual Development and Design Specification, http:/lacwc.sdp.sirsi.net/client/en_US/search/asset/1040680

As military installations face continued ecological changes caused by changing land use patterns, changing climate, invasive species, and changing missions, the need to forecast the implication of such changes on habitats and at-risk species continues to grow. This requires ecological simulation modeling approaches based on ecological knowledge of the interaction of ecological components at varying time and space scales, at varying ecological hierarchies, and mediated through numerous relationship networks. Because each location and system challenge is unique, a library-based ecological modeling system is required to create costeffective simulation models. A general purpose, cross-ERDC, widely-adopted ecological modeling system would provide a platform that allows model component reuse, multidisciplinary collaboration, and the ability to rapidly respond to emerging modeling challenges. This reports documents the development of a plan for the creation of an ERDC Ecological Modeling System (EMS) based on the challenges and needs expressed through two ERDCwide workshops held in 2011.

Kevin Bjella, Steve Arcone, and Thomas Douglas. 2015. ERDC/CRREL TR-15-14. Imaging of Ground Ice with Surface-based Geophysics, http:/lacwc.sdp.sirsi.net/client/search/asset/1045969

Electrical properties of earth materials have profound differences due to the phase change of water to ice. This contrast is useful when using electro-magnetic methods to study permafrost terrains where frozen and thawed materials are intermixed. Engineering and science are in need of efficient, non-invasive tools for imaging ice and sediment composition. Borehole information is often used to map ice in permafrost terrains; but it is time consuming, expensive, and can lead to over- or under-quantification of ground ice. Advances in computing power have led to refined surface-based geophysical methods, and the goal of this study was to determine if the latest commercial technologies or system were promising for imaging ground ice and associated features and to compare the results across a variety of permafrost terrains.

Electrical Resistivity Tomography (ERT), in particular, has been effective for imaging ground ice. ERT measures the ability of materials to conduct or resist an electric current. A variation of this method, capacitive coupled resistivity offers the ability for continuous data collection while moving across the landscape at scales of meters to kilometers. This greatly enhances the cost efficiency, applicability, and overall usefulness of the techniques and provides the ability to view variations in permafrost ice content on these larger scales.
Main vegetation and terrain characteristics along the two Farmers Loop transects resulting from seasonal thaw measurements
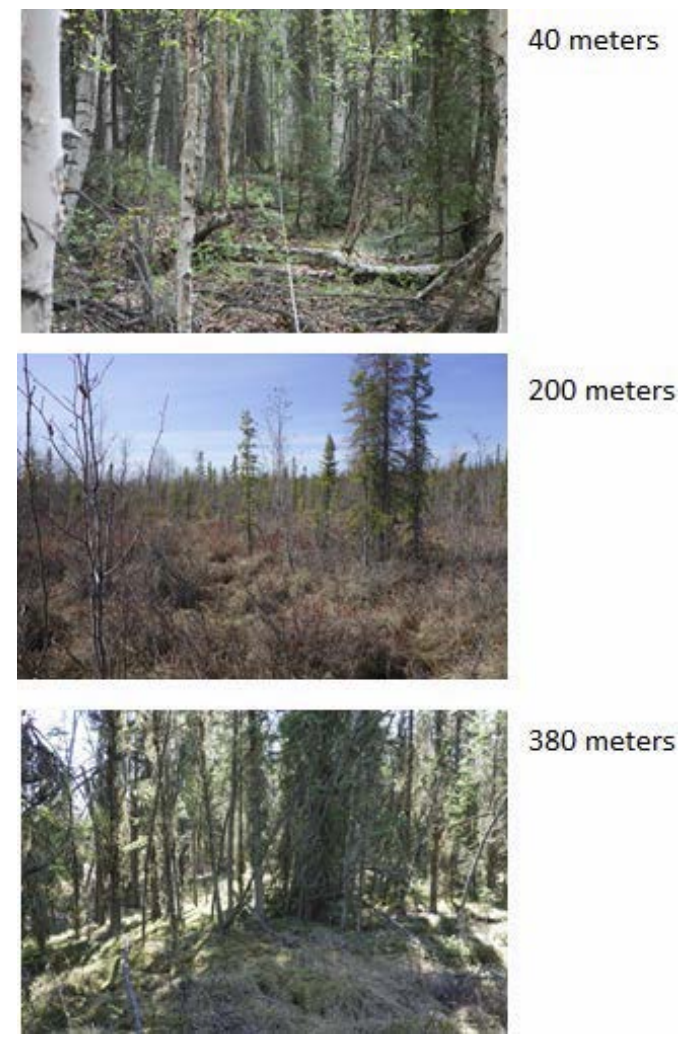


\section{Green Remediation and Reuse}

In achieving its mission, the Corps must provide quality and responsive services in a manner that is environmentally, economically, and socially sustainable.

The purpose of this focus area is to increase awareness and activity across the U.S. Army Corps of Engineers (USACE) and the Army for incorporating sustainable practices into their environmental remediation and reuse activities.

\section{Stephen D. Cosper. PWTB 200-1-151. Deconstruction of World War II-Era Buildings (Publication pending).}

The Army typically uses conventional methods to remove surplus buildings from its real property inventory and then landfills the demolished debris. Deconstruction, on the other hand, is the disassembly of a building to maximize the recovery of its salvageable materials. Deconstruction also can achieve a significant reduction in the solid waste volume going to landfill. The deconstruction process at Army installations can vary widely, depending on which of four options is chosen: (1) contracting the deconstruction to a private firm, (2) allowing the deconstruction contractor to retain salvaged materials as payment-in-kind, (3) allowing the deconstruction contractor to retain all salvaged material in exchange for reducing the contract price, or (4) donating salvaged materials to a nonprofit organization. This PWTB describes three case studies at Army installations that document and illustrate deconstruction practices, problems, and lessons learned.

Timber salvage at Twin Cities Army Ammunition Plant, MN in 1995.

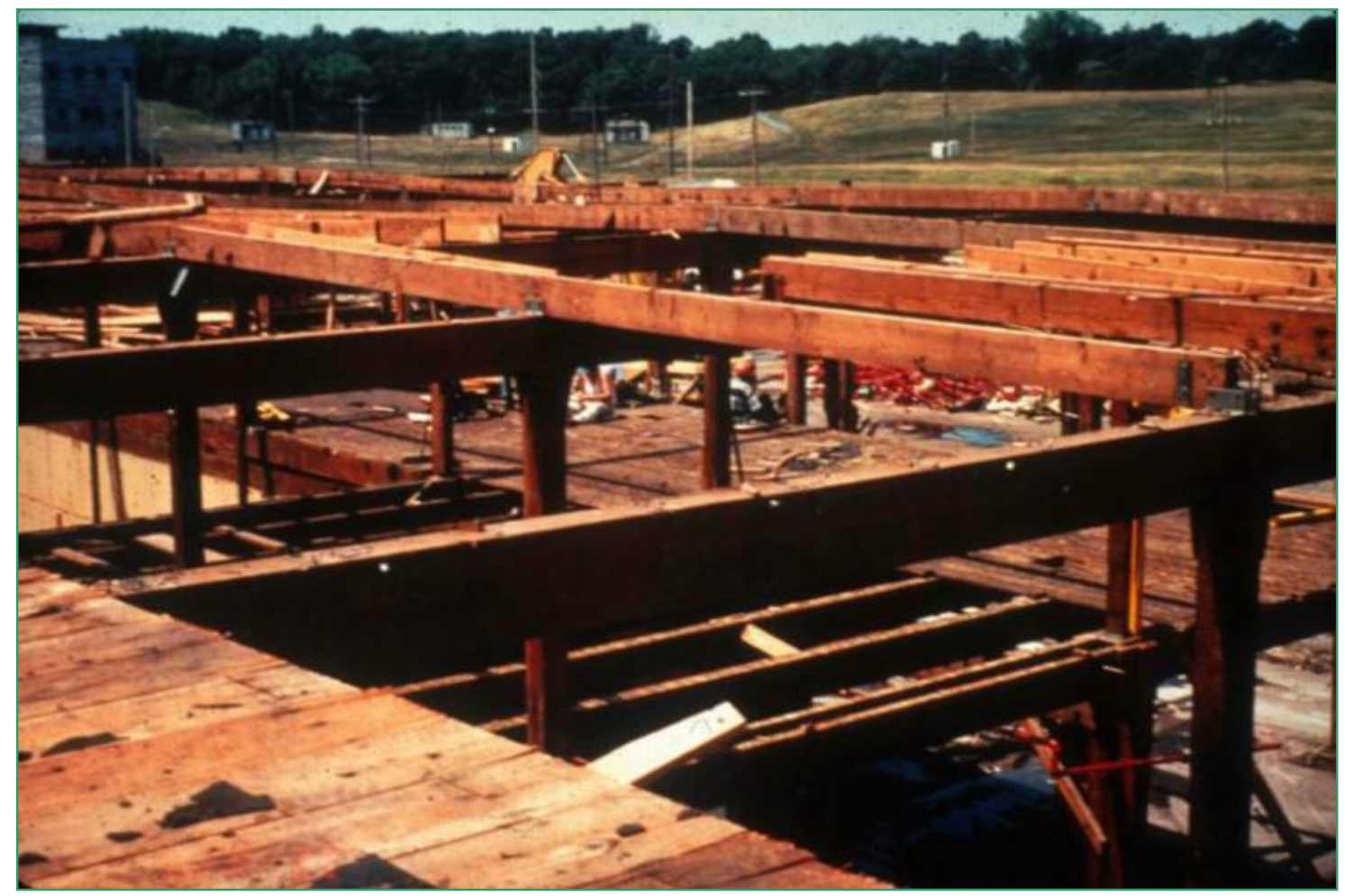


Stephen D. Cosper. PWTB 200-1-143. Update of Opportunities for Reducing Construction and Demolition Waste from Residential Communities Initiative (RCI) Programs, http://www.wbdg.org/ccb/ARMYCOE/PWTB/pwtb_200_1_143.pdf

C\&D debris accounts for up to $80 \%$ of some installations' solid waste streams. This large waste stream is most critical where an installation is removing large numbers of World War II-era wood buildings and where new construction programs such as the $\mathrm{RCl}$ require the demolition of existing facilities. Even if the Facility Reduction Program (FRP) and new MILCON programs are more modest, C\&D debris constitutes a significant solid waste burden for Army installations.

This work studied 12 family housing unit designs from four Army properties and one Air Force property. The buildings represented a large portion of the family housing buildings to be removed at Army installations, then and in the foreseeable future. The procedures and supporting data outlined in this PWTB allow for assessing the material content of buildings and will enable a relatively quick quantity take-off to be established to determine opportunities for debris reduction. It is important to note that no single quantity for material content is applicable to all buildings, construction types, and locations. Therefore, several building categories are described to address a range of project-specific conditions.

Niels G. Svendsen. PWTB 200-1-127. Vegetation Establishment Expectations for Erosion Control Blankets, http://www.wbdg.org/ccb/ARMYCOE/PWTB/pwtb 200 1 127.pdf

On construction and land rehabilitation projects, the presence of bare ground is a concern for the compliance and conservation efforts of contractors and land managers. Federal, state, and local regulatory requirements mandate that soil loss be minimized from those sites to preserve soil health and maintain clean waterways. Long-term ecological health of the land also requires that measures be taken to preserve soils in situ. In many areas, the best long-term solution is to establish vegetation. However, keeping soil in place while establishing a healthy stand of vegetation is frequently a challenge. This PWTB presents a discussion of the need for and utility of erosion control blankets (ECBs) to stabilize soil, prevent erosion, and maintain water quality on military lands. It also evaluates the rate of germination associated with an array of ECBs commonly used.

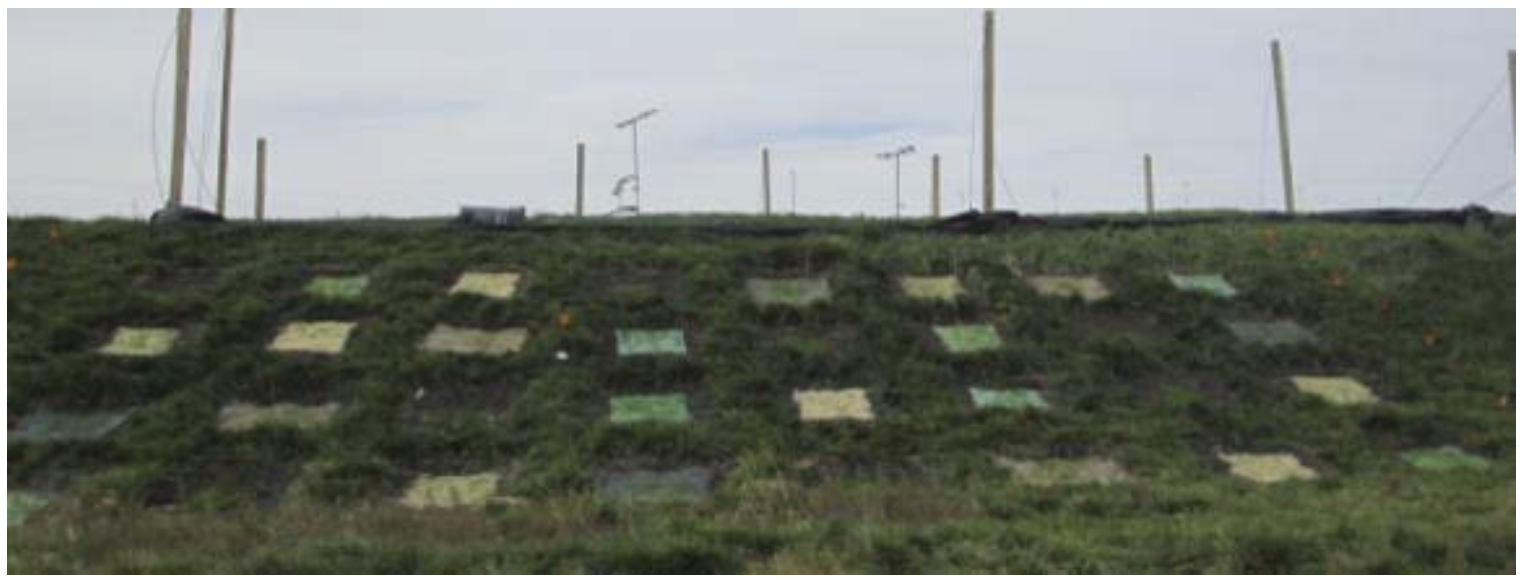

Seeded and blanketed vegetation establishment plots

Veera M. Boddu. PWTB 200-1-110. Environmentally Friendly Cleaners for Removing Tar and Asphalt from Tactical and Transportation Vehicles, http://www.wbdg.org/ccb/ARMYCOE/PWTB/pwtb_200_1 110.pdf

Ground Army vehicles that come into the maintenance facility commonly have "road tar" on their surfaces. Before a vehicle is washed or painted, the tar must be removed. The current method for removing bitumen from the vehicles involves the use of a high-pressure $(40,000$ psi) water jet, followed by manually scraping any residual asphalt. Any residual asphalt is manually scraped ("spot cleaned") using such commercial cleaning formulations. (Before 
using the water jet to remove residual tar from vehicles, the Army relied on (Military Standard) PD-680 type solvents and diesel fuel, highly refined aliphatic hydrocarbon compounds that have been phased out because they contain large amount HAPs and VOCs that negatively impact the environment. Such mechanical and manual vehicle cleaning and servicing methods are very expensive and inefficient. This PWTB presents an approach to evaluate commercial tar/asphalt cleaners, and identifies and provides recommendations for the selection of commercially available, environmentally friendly cleaners for removing road tar and asphalt from Army ground vehicles. The simple laboratory experiments described in this PWTB can be used to evaluate tar and asphalt cleaners.

Rosa T. Affleck, Meredith Carr, Laura Elliot, et al. 2014. ERDC/CRREL TR-14-15. Pollutant Concentrations in Runoff at McMurdo Station, Antarctica, http://acwc.sdp.sirsi.net/client/search/asset/1040384 Accidental spills and chemical contamination from leaking fuel and materials (lubricants, paints, etc.) at McMurdo Station have caused environmental concerns, and snowmelt runoff may tend to transport these contaminants. Therefore, this study quantified the pollutant types and levels in the runoff throughout a season. To understand what types of analytes were present and being carried by the runoff into Winter Quarters Bay, water samples were collected from the runoff at major flow arteries at McMurdo Station six times during various flow events in austral summer 2010-2011. Pollutants analyzed included heavy metals, polycyclic aromatic hydrocarbons (PAHs), total hydrocarbons, and VOCs. Results showed that concentrations for heavy metals were elevated during the first flush when flow began in receiving channels where significant operational or day-to-day activities occurred. In other places,

Drainage channel along the "Gasoline Alley" adjacent to the fueling station

elevated values occurred during the first significant flow; and the concentrations for selected PAHs were elevated during the first peak flow. Given that the snowmelt runoff contained significant concentration of heavy metals and certain PAHs, some of which were above the thresholds for chronic limits for aquatic water quality in saltwater, prevention and mitigation are crucial for reducing contamination at McMurdo Station.

Kevin Bjella. 2015. ERDC/CRREL TR-15-15. Naval Arctic Research Laboratory (NARL) Subsurface Containment Berm Investigation, http:/lacwc.sdp.sirsi.net/client/search/asset/1046351

The former Navy Arctic Research Laboratory Airstrip Site in Barrow, AK, has a history of fuel spills. Various methods have been used to remediate the site, including installing a subsurface containment berm and associated recovery trenches. The containment berm was designed to create a raised permafrost feature that effectively prevents free product migrating from the upstream side to the downstream side.

This study focused on using nonintrusive GPR techniques coupled with ground probing and desktop thermal analyses to assess if these methods could help to determine whether the containment berm is functioning as designed (i.e., effectively decreasing active-layer thickness and raising the permafrost table).

The results demonstrate that these GPR methods were useful for this study and that the berm is effectively raising the permafrost table along the survey transects explored. 


\section{Acronyms and Abbreviations}

\begin{tabular}{|c|c|}
\hline Term & Definition \\
\hline AFB & Air Force Base \\
\hline ANSI & American National Standards Institute \\
\hline ARCS & Air-Ride Cargo Sled \\
\hline ASA & Assistant Secretary of the Army \\
\hline ASA(IE\&E) & Assistant Secretary of the Army for Installations, Energy and Environment \\
\hline AT & Advanced Treatment \\
\hline AT\&T & American Telephone \& Telegraph \\
\hline BMP & Best Management Practice \\
\hline$C \& D$ & Construction and Demolition \\
\hline $\mathrm{CA}$ & Civil Affairs \\
\hline CASI & Center for the Advancement of Sustainability Innovations \\
\hline CB & Contingency Base \\
\hline CBITEC & Contingency Basing Integration Technology Evaluation Center \\
\hline CCAFSIAHD & Cape Canaveral Air Force Station Industrial Area Historic District \\
\hline $\mathrm{CCR}$ & Central Contractor Registration \\
\hline CERL & Construction Engineering Research Laboratory \\
\hline CNT & Carbon Nanotube \\
\hline CONUS & Continental United States \\
\hline $\mathrm{CP}$ & Cathodic Protection \\
\hline CRREL & Cold Regions Research and Engineering Laboratory \\
\hline DA & Department of the Army \\
\hline DAIM-ODF & OACSIM Facility Policy Division \\
\hline DCV & Demand Controlled Ventilation \\
\hline DFAC & Dining facility \\
\hline DFMWR & Directorate for Family, Moral, Welfare, and Recreation \\
\hline DFP & Deployable Force Protection \\
\hline DNA & deoxyribonucleic acid \\
\hline DNAN & 2.4-dinitroanisole \\
\hline DoD & U.S. Department of Defense \\
\hline DPW & Directorate of Public Works \\
\hline DSC & Differential Scanning Calorimetry \\
\hline DST & decision support template \\
\hline DTE & Defence Training Estate \\
\hline DTIC & Defense Technical Information Center \\
\hline EAL & Environmentally Acceptable Lubricant \\
\hline EALS & Environmentally Acceptable Lubricants \\
\hline EASEE & Environmental Awareness for Sensor and Emitter Employment \\
\hline ECB & Engineering and Construction Bulletin \\
\hline ECM & Energy Conservation Measure \\
\hline EFOB-L & ERDC-CERL Forward Operating Base Laboratory \\
\hline EISA & U.S. Energy Independence and Security Act of 2007 \\
\hline
\end{tabular}




\begin{tabular}{|c|c|}
\hline Term & Definition \\
\hline EKO & Engineering Knowledge Online $\mathrm{TM}^{\mathrm{TM}}$ \\
\hline EL & Environmental Laboratory \\
\hline EMI & Electro Magnetic Interference \\
\hline EMP & Electro-Magnetic Pulse \\
\hline EMPIRE & [U.S. Navy] Electromagnetic Propagation Integrated Resource Environment \\
\hline EMS & Energy Management System \\
\hline ERDC & U.S. Army Engineer Research and Development Center \\
\hline ERDC-CERL & Engineer Research and Development Center, Construction Engineering Research Laboratory \\
\hline ERT & Electrical Resistivity Tomography \\
\hline ESTCP & Environmental Security Technology Certification Program \\
\hline FHWA & Federal Highway Administration \\
\hline FOB & Forward Operating Base \\
\hline FRP & Fiber-Reinforced Polymer \\
\hline FVS-sn & Forest Vegetation Simulator - Southern Variant \\
\hline FWD & Falling Weight Deflectometer \\
\hline FY & Fiscal Year \\
\hline GAC & Granular Activated Carbon \\
\hline GFRP & Glass Fiber Reinforced Polymer \\
\hline GHG & Greenhouse Gas \\
\hline GIS & Geographic Information System \\
\hline GPR & ground penetrating radar \\
\hline HAP & Hazardous Air Pollutant \\
\hline HFMA & Heat Flow Meter Apparatus \\
\hline HPLV & High-Pressure, Low-Volume \\
\hline HTF & Heat-Transfer Fluid \\
\hline IGY & International Geophysical Year \\
\hline IM & Insensitive Munition \\
\hline INRMP & Integrated Natural Resources Management Plans \\
\hline ITAM & Integrated Training Area Management \\
\hline JTRC & Joint Training and Readiness Center \\
\hline KMC & Kilauea Military Camp, HI \\
\hline $\mathrm{KRC}$ & Keweenaw Research Center \\
\hline LA & load allocation \\
\hline LEED & Leadership in Energy and Environmental Design \\
\hline LID & Low Impact Development \\
\hline LiDAR & Light Detection and Ranging \\
\hline LMPT & Leaders Mission Planning Tool \\
\hline LPHV & Low-Pressure, High-Volume \\
\hline LR & Letter Report \\
\hline LVOC & Low Volatile Organic Compound \\
\hline LWIR & Long-Wave Infrared \\
\hline MILCON & Military Construction \\
\hline MIS & management information system \\
\hline MP & Miscellaneous Paper \\
\hline MPCM & Microencapsulated Phase-Change Material \\
\hline MSW & Municipal Solid Waste \\
\hline
\end{tabular}




\begin{tabular}{|c|c|}
\hline Term & Definition \\
\hline MWS & Modular Wetlands ${ }^{\mathrm{TM}}$ \\
\hline NACE & National Association of Corrosion Engineers \\
\hline NARL & Naval Arctic Research Laboratory \\
\hline NEXION & Next Generation lonosonde \\
\hline NHARNG & New Hampshire Army National Guard \\
\hline NHDOT & New Hampshire Department of Transportation \\
\hline NHPA & National Historic Preservation Act of 1966 \\
\hline NIS & non-indigenous invasive species \\
\hline NQ & nitroguanidine \\
\hline NRHP & National Register of Historic Places \\
\hline NSF & National Science Foundation \\
\hline NSF-PLR & National Science Foundation, Division of Polar Programs \\
\hline NSN & National Supply Number \\
\hline NTO & 3-Nitro-1,2,4-triazol-5-one \\
\hline NYANG & New York Air National Guard \\
\hline NZE & Net Zero Energy \\
\hline NZEI & Net Zero Energy Installation \\
\hline NZI & Net Zero Installation \\
\hline NZP & Net Zero Planner \\
\hline NZW & Net-Zero Water \\
\hline OACSIM & Office of the Assistant Chief of Staff for Installation Management \\
\hline OACSIM-IE\&E & Assistant Secretary of the Army for Installations Management, Energy, and Environment \\
\hline OCONUS & Outside Continental United States \\
\hline OMB & Office of Management and Budget \\
\hline OPAL & Optimal Programming of Army Lands \\
\hline OSAF & Optimal Stationing of Army Forces \\
\hline PAH & Polycyclic Aromatic Hydrocarbon \\
\hline PCB & Polychlorinated Biphenyl \\
\hline PCM & Phase Change Material \\
\hline PMF & Probable Maximum Flood \\
\hline POL & Petroleum, Oil, and Lubricants \\
\hline PTA & Pohakuloa Training Area \\
\hline PV & PhotoVoltaic \\
\hline PVC & Polyvinyl Chloride \\
\hline PWTB & Public Works Technical Bulletin \\
\hline $\mathrm{RCl}$ & Residential Communities Initiative \\
\hline RCW & Red-cockaded Woodpecker \\
\hline RDX & cyclotrimethylene-trinitramine \\
\hline RFS & Renewable Fuels Standards \\
\hline RNA & Ribonucleic Acid \\
\hline RO & Reverse Osmosis \\
\hline ROI & Return on Investment \\
\hline RTLA & Range and Training Land Assessment \\
\hline SAR & Species at Risk \\
\hline SBT & Scott Base Transition \\
\hline SCA & Snow Covered Area \\
\hline
\end{tabular}




\begin{tabular}{|c|c|}
\hline Term & Definition \\
\hline SDD & Sustainable Design and Development \\
\hline SDD DX & Sustainable Design and Development Directory of Expertise \\
\hline SEM & Scanning Electron Microscope \\
\hline SF & Standard Form \\
\hline SIRRA & Sustainable Installations Regional Resource Assessment \\
\hline SMP & Sustain the Mission Project \\
\hline SP & static pressure \\
\hline SPoT & South Pole Traverse \\
\hline SR & Special Report \\
\hline SSMR & Standing-Seam Metal Roof \\
\hline SSPP & (DoD) Strategic Sustainability Performance Plan \\
\hline SWE & Snow Water Equivalent \\
\hline TEPC & Threatened, Endangered, Proposed, and Candidate \\
\hline TES & Threatened and Endangered Species \\
\hline TGA & Thermogravimetric Analysis \\
\hline TN & Technical Note \\
\hline TR & Technical Report \\
\hline UAS & Unmanned Aerial System \\
\hline UK & United Kingdom \\
\hline USACE & U.S. Army Corps of Engineers \\
\hline USAP & United States Antarctic Program \\
\hline USEPA & U.S. Environmental Protection Agency \\
\hline USGBC & U.S. Green Building Council \\
\hline USMMA & U.S. Merchant Marine Academy \\
\hline UTA & Urban Training Area \\
\hline VIIRS & Visible Infrared Imaging Radiometer Suite \\
\hline VOC & Volatile Organic Compound \\
\hline WASP & WAter Stress Projection \\
\hline WCM & Water Conservation Measure \\
\hline XPS & Extruded Polystyrene \\
\hline
\end{tabular}




\section{Included Documents}

Focus Area / Document

\section{Anticipating Emerging Issues}

Identification of Insect-Plant Pollination Networks for a Midwest Installation: Fort McCoy, WI

Clustered Regularly Interspaced Short Palindromic Repeat/CRISPR-associated protein 9 (CRISPR/Cas9)-based

Gene Drives for Invasive Species Management on Military Lands

Extreme Environment Basing: Contingency Basing in Dense Urban and Megacity Environments

Assessment of Small Arms Munitions Impacts on Natural Infrastructure in Sensitive Downrange Areas on

Military Installations

Energy and Resource Recovery from Wastewater Treatment: State of the Art and Potential Application for the Army and the DoD

\section{Climate Change}

Water Stress Projection Modeling

Integrated Climate Assessment for Army Enterprise Planning

Use of Heat and Fire-Risk Indices to Project Local Climate Impacts on Selected Army Installations

Effects of Climate Change and Urban Development on Army Training Capabilities: Firing Ranges and Maneuver Areas

Application of Maxent Multivariate Analysis to Define Climate-Change Effects on Species Distributions and Changes

Effects of Climate Change, Urban Development, and Threatened and Endangered Species Management on

Army Training Capabilities

Multivariate Bioclimatic Ecosytem Change Approaches

Indicators of Physical and Biological Trends around the McMurdo Station: A Literature Review

Socio-economic Effects of Drought in the Horn of Africa: Population Movements, Livelihoods, and Market

Prices

\section{Sustainable Installations - Net-Zero Planning}

Demonstration of The Energy Component of The Installation Master Plan Using The Net Zero Planner

Net Zero Energy Water Waste Portfolio for Fort Leonard Wood

Demonstrate Energy Component of The Installation Master Plan Using "Net Zero Energy Installation Tool"

Considerations for Net-Zero Waste Installations

\section{Sustainable Energy Solutions}

Biofuel Production: Considerations for USACE Civil Works Business Lines

Simulated Aging and Characterization of Phase Change Materials for Thermal Management of Building

Envelopes

Using Thermal Bridging Factors in Energy Models

Exhaust Hood and Makeup Air Optimization

Kinetic Super-Resolution Long-Wave Infrared (LWIR) Thermography Diagnostic for Building Envelopes

Kinetic Super-Resolution Long-Wave Infrared (LWIR) Thermography Diagnostic for Building Envelopes: Scott

AFB, IL

Kinetic Super-Resolution Long-Wave Infrared (LWIR) Thermography Diagnostic for Building Envelopes: Camp

Lejeune, NC

Prediction of Long Term Degradation of Insulating Materials

Level I Energy and Water Survey, ERDC-CERL, Champaign, IL

Field Validation of Microencapsulated Phase-Change Material Slurries as Heat-Transfer Fluids

Energy and Resource Recovery from Wastewater Treatment: State of the Art and Potential Application for the

Army and the DoD 


\section{Sustainable Water \& Waste Resources}

Implementing Stormwater and Erosion Control Technologies in Urban-Type Military Range Designs 24

Toxics Management 25

Recycle of Solvent Cleaners for Tactical and Transportation Vehicles 25

Base-Wide Biodigester for Basecamps in an Operational Environment 25

Energy and Resource Recovery from Wastewater Treatment: State of the Art and Potential Application for the

Army and the DoD

Assessment of Composting for Organic Solid Waste at Fort Polk, Louisiana 27

Waste Water Handling Proof of Concepts at McMurdo Station, Antarctica 27

\section{Sustainable Facilities and Infrastructure}

Update of Opportunities for Reducing Construction and Demolition Waste from Residential Communities Initiative (RCI) Programs

Application of Updated Construction and Demolition Waste Reduction Policy for Army Projects 29

Removing Hazardous Materials from Buildings: A Training Curriculum 29

Finding Space: A Field Guide for Incorporating Low Impact Developments into Military Historic Districts 29

Multinational Analysis of Military Vehicle Impacts and Regulatory Pressures on Training Land Management 30

Creative Strategies and Opportunities for Managing Cultural Resources on Army Training Lands

[F09-AR02] Demonstration and Validation of Materials for Corrosion-Resistant Fencing and Guard Railings in Aggressive Climates

[F08-AR14] Demonstration of Photovoltaic-Powered Cathodic Protection System with Remote Monitoring Capability

Terrain and The Physical Environment: Factors for Noise Mitigation

Multifunctional Nanocomposites for Improved Sustainability and Protection of Facilities

Developing Baselines for Prescribed Burning Smoke Management Plans and Best Management Practices

[F10-AR01] Corrosion-Resistant Coatings for Air-Conditioning Coils and Fans

Infrastructure and the Operational Art: A Handbook for Understanding, Visualizing, and Describing

Infrastructure Systems

Evaluation of Demonstrated Bioswale

Demonstration of a Modular Wetland Treatment System for Stormwater Runoff

Evaluation of Centralized Vehicle Wash Facilities for Invasive Species Removal

OPAL Netlogo Land Condition Model: Application and Validation at Fort Riley, KS

[F10-AR08] Demonstration and Validation of Vinyl Coating Systems for Cold Locations

[F09-AR04] Demonstration of a Corrosion-Resistant Roof System with Integrated Photovoltaic Power System

Inventory and Evaluation of Buildings in the Industrial Area, Cape Canaveral Air Force Station

Regional Analysis of Historic Farmstead Archeological Site Characteristics on DoD Installations

The Army and the FHWA Program Comment for Common, Post-1945 Concrete and Steel Bridge

Architectural Survey of Ohio Army National Guard Properties: Volume I - Main Report

Camp Sherman, Ohio: History of a World War I Training Camp

William Barstow Mansion of The United States Merchant Marine Academy: Nomination to the National

Register of Historic Places

United States Merchant Marine Academy Historic District: Nomination to the National Register of Historic Places

Matthew Jones House: Historic Maintenance and Repair Manual

Fort Leonard Wood Building 2101: Interior Character-Defining Features, Inventory and Assessment

Character-Defining Features of Contributing Buildings and Structures in the United States Merchant Marine Academy Historic District 
Evaluation of Environmentally Acceptable Lubricants (EALS) for Dams Managed by the U.S. Army Corps of Engineers

Analysis of Operational Data: A Proof-of Concept for Assessment of Electrical Infrastructure Impact

Elevated Building Lift System in Polar Environments Workshop

Preliminary Guidelines and Standard Operating Procedure for Drainage and Erosion Control at McMurdo Station

Site Assessment and Feasibility of a New Operations Base on the Greenland Ice Sheet: Addendum to the

Preliminary Report

Extending the Season for Concrete Construction and Repair: Phase III-Guidance for Optimizing Admixture

Dosage Rates

Vehicle Impact Testing of Snow Roads at McMurdo Station, Antarctica

Evaluation of a New SnowPaver at McMurdo Station, Antarctica

Development of Conceptual Designs for Prevention of Ice Formation in the Proposed Maple River Open

Aqueduct

Antarctic Camps Snow Drift Management Handbook

Design and Implementation of a Consolidated Airfield at McMurdo, Antarctica

Low-Temperature Flex Durability of Fabrics for Polar Sleds

Maintenance and Drainage Guidance for the Scott Base Transition, Antarctica

Flow Control and Design Assessment for Drainage System at McMurdo Station, Antarctic

Vertical Temperature Simulation of Pegasus Runway, McMurdo Station, Antarctica

Remediation of Old South Pole Station Using Autonomous Data Collection and Remote Assessment of

Ground-Penetrating Radar

Geotechnical Study, Next Generation Ionosonde (NEXION) Installation, Thule Air Base, Greenland

\section{Sustainable Contingency Basing}

Design Enhancements to Facilitate a Sustainable and Energy Efficient Dining Facility (DFAC) in a Contingency

Environment

Mold Remediation and Recommendations to Resolve Other Major Issues in Concrete B-Huts at Bagram

Airfield, Afghanistan

Anaerobic Digestion Assessment for Contingency Base Waste

\section{Sustainable Natural Infrastructure}

Assessment of Small Arms Munitions Impacts on Natural Infrastructure in Sensitive Downrange Areas on

Military Installations

Forest Microclimate Characteristics: Annotated Bibliography

Using Simple Environmental Variables to Estimate Biomass Disturbance

Evaluation of Suitable Population and Habitat Suitability Models for Endangered Avian Species Populations on Fort Hood, $T X$

Rapid Assessment of Disturbances and Landscape Features Using a Tethered Low-Level Aerial Digital

Photography System 
Ecological Modeling System: Conceptual Development and Design Specification

Imaging of Ground Ice with Surface-based Geophysics

Green Remediation and Reuse

Deconstruction of World War II-Era Buildings

Update of Opportunities for Reducing Construction and Demolition Waste from Residential Communities Initiative (RCI) Programs

Vegetation Establishment Expectations for Erosion Control Blankets

Environmentally Friendly Cleaners for Removing Tar and Asphalt from Tactical and Transportation Vehicles

Pollutant Concentrations in Runoff at McMurdo Station, Antarctica

Naval Arctic Research Laboratory (NARL) Subsurface Containment Berm Investigation 


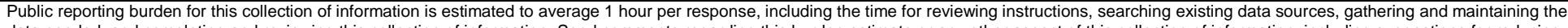

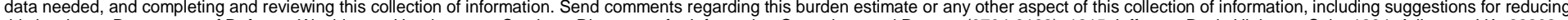

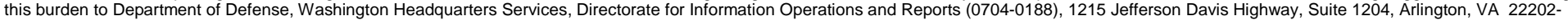

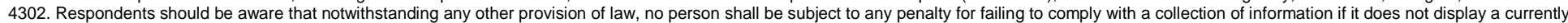
4302. Respondents should be aware that notwithstanding any other provision of law, no person sh
valid OMB control number. PLEASE DO NOT RETURN YOUR FORM TO THE ABOVE ADDRESS.

\begin{tabular}{l|l} 
valid OMB control number. PLEASE DO NOT RETURN YOUR FORM TO THE ABOVE ADDRESS. \\
\hline 1. REPORT DATE (DD-MM-YYYY)
\end{tabular}

03-03-2016

\section{TITLE AND SUBTITLE}

Sustainability-Related Publications: Calendar Years 2014 - 2015

\section{Final}

3. DATES COVERED (From - To)

5a. CONTRACT NUMBER

5b. GRANT NUMBER

5c. PROGRAM ELEMENT

6. AUTHOR(S)

Franklin H. Holcomb

\section{5d. PROJECT NUMBER}

5e. TASK NUMBER

5f. WORK UNIT NUMBER

8. PERFORMING ORGANIZATION REPORT NUMBER

7. PERFORMING ORGANIZATION NAME(S) AND ADDRESS(ES)

U.S. Army Engineer Research and Development Center (ERDC)

Construction Engineering Research Laboratory (CERL)

PO Box 9005,

ERDC/ CERL TN-16-2

Champaign, IL 61826-9005

\section{SPONSORING I MONITORING AGENCY NAME(S) AND ADDRESS(ES)}

U.S. Army Engineer Research and Development Center (ERDC)

Construction Engineering Research Laboratory (CERL)

PO Box 9005 ,

Champaign, IL 61826-9005

11. SPONSOR/MONITOR'S REPORT NUMBER(S)

\section{DISTRIBUTION I AVAILABILITY STATEMENT}

Approved for public release; distribution is unlimited.

\section{SUPPLEMENTARY NOTES}

\section{ABSTRACT}

The Center for the Advancement of Sustainability Innovations (CASI) was established by the U.S. Army Engineer Research and Development Center (ERDC) as a new capability in 2006 to be hosted at the Construction Engineering Research Laboratory (CERL) in Champaign, IL. CASI was established with the goal of focusing the value of ERDC expertise, technologies, and partnerships toward helping the U.S. Army Corps of Engineers (USACE), the Army, and the Department of Defense (DoD) achieve more sustainable facilities and operations. CASI provides the military with capabilities that enhance national security through more effective use of limited resources and improved coordination and partnerships with host communities and stakeholders in the United States and around the globe. In all efforts, CASI teams strive to measure sustainability innovations against the Triple Bottom Line of mission, environment, and community. In addition, CASI focuses on cost savings, innovation, collaborative solutions, and continuous learning, all of which directly link sustainability to Army Business Transformation and the Army Campaign Plan. Of special note is the inclusive nature of that this "summary of sustainability-related publications," which incorporates descriptions of work related to the theme of sustainability that was conducted under many ERDC programs as well as CASI.

\section{SUBJECT TERMS}

CASI, Center for the Advancement of Sustainability Innovations, Army, environment, sustainability

\section{SECURITY CLASSIFICATION OF:}

\section{a. REPORT}

Unclassified

\section{b. ABSTRACT}

Unclassified

\section{LIMITATION} OF ABSTRACT

c. THIS PAGE

Unclassified
SAR

\section{NUMBER} OF PAGES

78 19a. NAME OF RESPONSIBLE PERSON

19b. TELEPHONE NUMBER (include area code) 